UNIVERSIDADE DE SÃO PAULO

INSTITUTO DE PSICOLOGIA

SÉRGIO PAES DE BARROS

A Promoção de Qualidade de Vida para os Trabalhadores:

Discurso, Poder e Disciplina

Dissertação apresentada ao Instituto de Psicologia da Universidade de São Paulo, como parte dos requisitos para obtenção do título de Mestre em Psicologia.

São Paulo 
SÉRGIO PAES DE BARROS

\title{
A Promoção de Qualidade de Vida para os Trabalhadores: Discurso, Poder e Disciplina
}

\begin{abstract}
Dissertação apresentada ao Instituto de Psicologia da Universidade de São Paulo, como parte dos requisitos para obtenção do título de Mestre em Psicologia.
\end{abstract}

Área de concentração: Psicologia Social Orientadora: Prof.a Dra. Leny Sato

São Paulo 


\section{AUTORIZO A REPRODUÇÃO E DIVULGAÇÃO TOTAL OU PARCIAL DESTE TRABALHO, POR QUALQUER MEIO CONVENCIONAL OU ELETRÔNICO, PARA FINS DE ESTUDO E PESQUISA, DESDE QUE CITADA A FONTE.}

Catalogação na publicação

Biblioteca Dante Moreira Leite

Instituto de Psicologia da Universidade de São Paulo

Barros, Sérgio Paes de.

A promoção de qualidade de vida para os trabalhadores: discurso, poder e disciplina / Sérgio Paes de Barros; orientadora Leny Sato. -São Paulo, 2010.

$183 \mathrm{f}$.

Dissertação (Mestrado - Programa de Pós-Graduação em Psicologia. Área de Concentração: Psicologia Social) - Instituto de Psicologia da Universidade de São Paulo.

1. Psicologia organizacional 2. Qualidade de vida 3. Recursos humanos 4. Discurso 5. Poder 6. Disciplina I. Título. 
A Promoção de Qualidade de Vida para os Trabalhadores:

Discurso, Poder e Disciplina

\section{SÉRGIO PAES DE BARROS}

BANCA EXAMINADORA

(nome e assinatura)

(nome e assinatura)

(nome e assinatura)

Dissertação defendida e aprovada em

1 


\section{Agradeço}

À população que financia a USP, a FAPESP e dezenas de outros órgãos que permitem que pesquisas como esta sejam realizadas e possibilitem que o Brasil possua autonomia na produção de conhecimento.

À empresa pesquisada e aos trabalhadores que permitiram que eu transitasse tantas vezes em seu cotidiano, muitas vezes causando estranhamento e incômodos, porém sempre me tratando da melhor forma possível. Aos trabalhadores entrevistados, bem como a todos os participantes do RH-Group e seus coordenadores, por abrirem as portas a esta pesquisa. Todos os trabalhadores que foram sujeitos desta pesquisa possuem, certamente, co-autoria desta dissertação.

À Professora Leny Sato pela rigorosa dedicação em minha orientação, pela leitura atenta de cada versão e também pela paciência. Durante os anos de orientação, nunca deixei de me surpreender pela sua capacidade de se encantar pelas idéias e projetos dos alunos, inclusive (e principalmente) os da graduação.

Ao Professor Marcelo Afonso Ribeiro, pelas indicações de leituras para as primeiras elaborações do projeto de mestrado, bem como pela leitura atenta e sugestões na ocasião do Exame de Qualificação.

Ao Professor Peter Kevin Spink, pela generosidade com que se dedicou a elaborar extensas e profundas sugestões a esta dissertação, na ocasião do Exame de Qualificação, e por me encorajar a trabalhar com Foucault.

À Marinalva Almeida Santos Gil e Maria Cecília Rodrigues de Freitas, secretárias do PST, por serem incrivelmente competentes, prestativas e, principalmente, pacientes.

Aos alunos de graduação que tive o prazer de acompanhar durante estes anos de mestrado, ao participar de suas reuniões de orientação de Iniciação Científica, disciplinas Prática de Pesquisa em Psicologia I e II: Carla F. Andrade, Beatriz Diniz, Vivian Pisaneschi, Juliana Thomaz, Rafael, Mariana, Thiago, Milena, Ailton Almeida, Amarina Monteiro e outros. Agradeço também pelos ensinamentos profundos dos alunos de intercâmbio Maria da Graça Filipe Cardoso e Pedro Horacio Caballero, com os quais todo o grupo aprendeu muito.

Ao grupo de orientandos de mestrado e doutorado da Professora Leny Sato, pelas suas sugestões e críticas: Matheus Castro, Renata Paparelli, Cris Andrada, Egeu Gomez, Lia Vainer, Juliana Nobrega, Ana Maria R. Carvalho e Paulo C. Seron, bem como aos orientandos de outros 
professores que nos presenteavam com sua presença, como Agnaldo Gomes e Patrícia P. Paula.

À Tatiana Neves e a Fábio Oliveira, por terem me ensinado diferentes estilos de lidar com pesquisas de campo, durante as reuniões com alunos da graduação.

Aos meus amigos André A. I. Oda, Daniel F. Chiacchio, Thiago S. A. Fonseca, Luiz Alberto S. Ribeiro, Matheus S. Menezes, Marçal A. Harada e ao meu irmão Fernando P. Barros Jr. por todas as conversas e debates que tivemos. Muitas vezes, sem saber, contribuíram para as reflexões aqui presentes.

Aos meus pais, que, de uma forma ou de outra, realmente contribuíram para formar o psicólogo social que hoje sou.

À Juliana, minha namorada e companheira, pela dedicação e carinho.

Aos meus colegas da graduação, hoje colegas de profissão, pelas conversas e sugestões. Ivan Nascimento, Renato Mori, Fabiana Catanzaro, Luiz Moreno, Lúcia Harumi de Paiva, Cíntia Vasques, Daniela Smid, Priscila Wuo, Samanta P. Natalo, Rafael Baioni e Mathias Glens, dentre outros.

Ao parecerista da FAPESP pelas generosas sugestões dadas no parecer do relatório parcial e pelo parecer profundo e atento do relatório final.

À FAPESP, por ter-me concedido bolsa de mestrado e possibilitado dedicação integral a esta pesquisa. 


\section{RESUMO}

BARROS, Sérgio Paes de. (2010) A Promoção de Qualidade de Vida para os Trabalhadores: Discurso, Poder e Disciplina. Dissertação de Mestrado. Instituto de Psicologia da Universidade de São Paulo, São Paulo, 2010, 183p.

Esta pesquisa parte de questões suscitadas durante a observação de eventos e treinamentos ligados à promoção de Qualidade de Vida para os Trabalhadores. Nosso objetivo é refletir sobre como os discursos ligados à QVT buscam criar sujeitos, quais mecanismos disciplinares utiliza e como os trabalhadores reinterpretam estes discursos.

Baseando-nos no método arqueológico foucaultiano, esquadrinhamos diversas publicações nacionais sobre o termo Qualidade de Vida no Trabalho. Realizamos incursões no cotidiano de uma empresa de grande porte, experiências junto a um grupo de profissionais de Recursos Humanos e entrevistas com profissionais ligados à Programas de QVT. As entrevistas e os espaços pesquisados apresentaram múltiplas dimensões do fenômeno da promoção de qualidade de vida para os trabalhadores, constituindo uma bricolage de modos de controle, organização e gestão do trabalho. Os discursos analisados remetiam a um estilo de vida apresentado como saudável e pouco diziam respeito às condições de trabalho ou à organização deste. A primazia do estilo, atitude e comportamentos sobre as condições concretas do trabalho, em discursos organizacionais que buscam moldar a subjetividade do trabalhador, configura o que Gorz (2005) chamou de mundo do trabalho imaterial.

Concluímos que os treinamentos e eventos destinados a fazer o trabalhador aderir a este estilo de vida caracterizavam-se como mecanismos disciplinares de controle e exercício de poder mediante o uso do discurso da QVT. Concluímos também que, para além do poder disciplinar observado, o discurso de qualidade de vida é utilizado para promover uma disseminação de valores e normas não somente aos trabalhadores, mas com vistas a toda a sociedade, em assuntos variados que classicamente não dizem respeito às organizações, remetendo-nos às noções de biopoder e governamentalidade, tais como desenvolvidas por Foucault (2005).

\section{Palavras-chave:}

Psicologia. Psicologia Social. Psicologia do Trabalho. Discurso. Poder. Disciplina. Sujeito. Qualidade de Vida para os Trabalhadores. Gestão de Pessoas. Recursos Humanos. Pesquisa Qualitativa. 


\begin{abstract}
BARROS, Sérgio Paes de. (2010) The Promotion of Quality of Life for Workers: Discourse, Power and Discipline. Master's Thesis. Institute of Psychology, University of São Paulo, São Paulo, 2010, 183pp.

This research was started on issues raised during the observation of events and trainings related to the promotion of quality of life for workers. Our goal is to reflect upon discourses about QWL and how it aims to create subjects, which disciplinary mechanisms it uses and how workers reinterpret these discourses.

Based in Foucault's archaeological method, we scrutinize several national publications about Quality of Life at Work. We did incursions in the daily business of a large company, experiences with a group of $\mathrm{HR}$ professionals and interviews with professionals involved in QWL programs. The interviews and the areas surveyed showed multiple dimensions of the phenomenon of promoting quality of life for people, forming a bricolage of methods of control, organization and work management. Discourses analyzed referred to a lifestyle presented as healthy and are not related to working conditions or working organization. The primacy of style, attitude and behavior on the concrete conditions of work in organizational discourses that seek to shape the subjectivity of workers, forms what Gorz (2005) has called world of immaterial labor.

We have concluded that the training and events to make workers adhere to this lifestyle are characterized as disciplinary mechanisms of control and exercise of power through the use of the discourse of QWL. We have also concluded, in addition to the disciplinary power noted, that the discourse of quality of life is used to promote the dissemination of values and norms not only for workers, but also focusing on the whole society, on varied subjects that traditionally do not relate to organizations, sending us to the notions of biopower and governmentability, such as developed by Foucault (2005).
\end{abstract}

\title{
Keywords:
}

Psychology; Social Psychology; Work Psychology; Discourse; Power; Discipline; Subject; Quality of Life for Workers; People Management; Human Resources; Qualitative Research 


\section{SUMÁRIO}

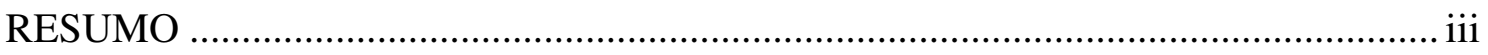

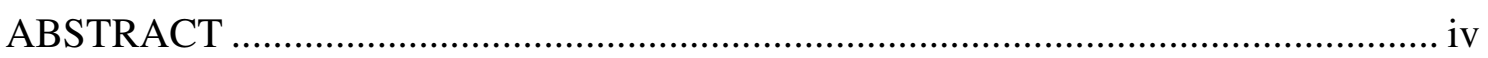

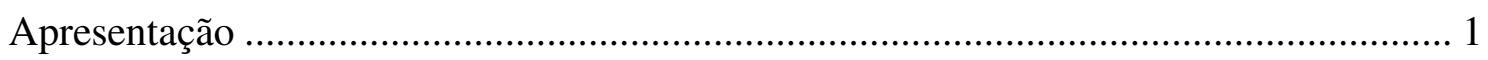

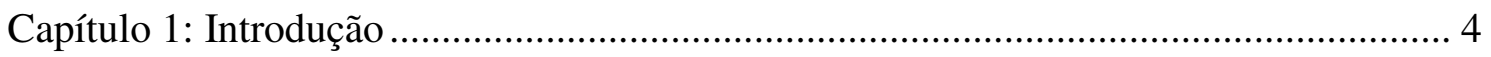

Capítulo 2: Arqueologia, Saber e Poder. ................................................................... 8

2.1) Foucault: A Arqueologia e a constituição do saber-poder ............................... 9

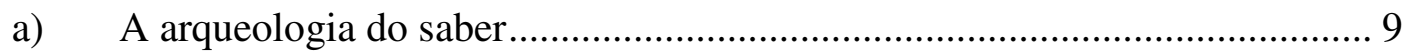

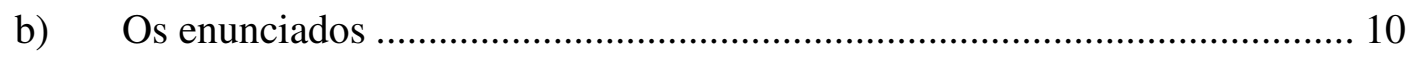

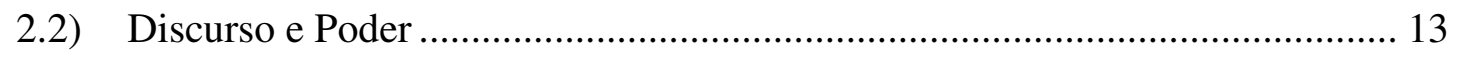

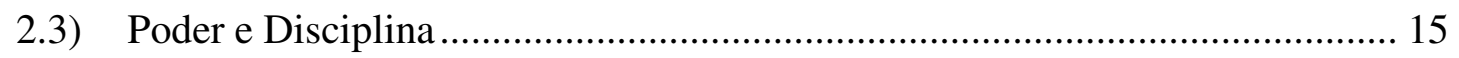

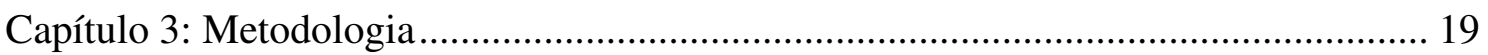

3.1) O Campo de pesquisa enquanto Campo-Tema .............................................. 20

3.2) Ferramentas teórico-metodológicas: arqueologia do discurso, observação

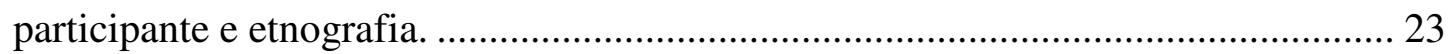

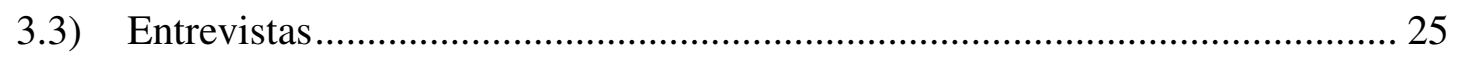

Capítulo 4: O sujeito do trabalho racionalizado: do cronômetro ao

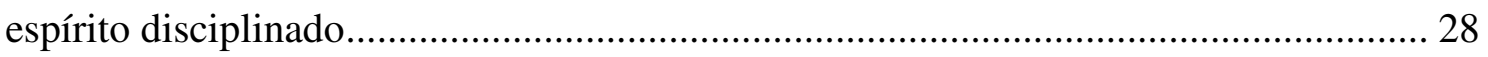

4.1) Do Taylorismo ao Modelo Japonês.................................................................... 29

4.2) Novos Modelos de Gestão de Pessoas nas Empresas .......................................... 36

4.2.1) Eixo Gestão por Competências ................................................................. 37

4.2.2) Eixo Gestão do Conhecimento ................................................................. 40

4.2.3) Eixo Organizações de Aprendizagem ........................................................ 43

4.3) Da imaterialidade do trabalho e suas transformações ........................................ 47

4.3.1) Sobre o discurso pós-moderno acerca do trabalho.................................... 48

Capítulo 5: Sobre o termo "Qualidade de Vida no Trabalho": Em busca de uma

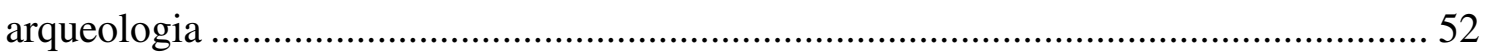

5.1) Publicações pioneiras no Brasil sobre o tema QVT........................................ 54

5.2) Sobre a origem do termo Qualidade de Vida no Trabalho .............................. 57

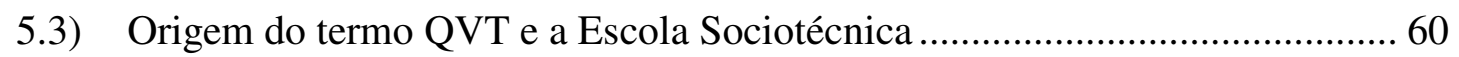

5.4) QVT como decorrência do modelo de Qualidade Total ................................... 62

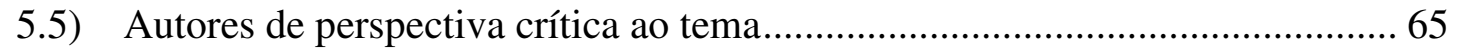

5.6) Algumas considerações sobre esta análise documental ................................ 69 
Capítulo 6: Reuniões de Profissionais de_Recursos Humanos: O RH-Group 72

6.1) Treinamento: Gerenciamento do Estresse e Qualidade de Vida no Trabalho.... 75

6.2) Treinamento: Vida Ativa - O jogo da qualidade de vida. 88

Capítulo 7 : Caso de um Programa premiado de QVT: bom para quem? 101

Capítulo 8: A Empresa ESB 115

8.1) Caracterização Geral da Empresa ESB ...................................................... 116

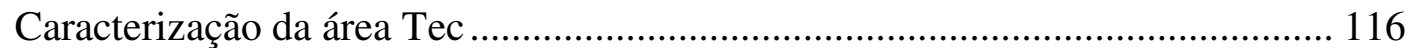

8.2) O Programa de Qualidade de Vida da ESB..................................................... 118

8.2.1) Os módulos do Programa de QV “Viver Feliz"..................................... 123

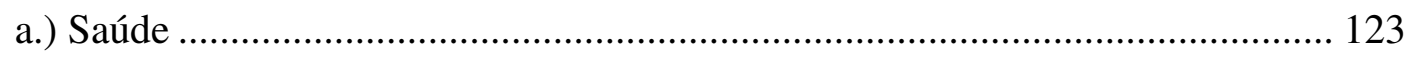

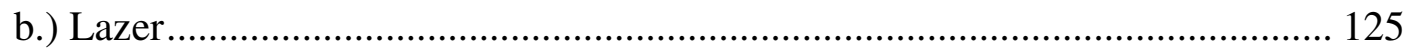

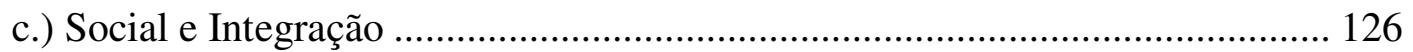

d.) Segurança do Trabalho............................................................................. 128

8.2.2) Sobre a "Mensagem Final" presente no Manual Viver Feliz ................. 131

8.3) O Programa Local de Qualidade de Vida da área Tec................................... 133

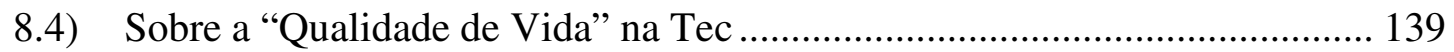

8.5) O limite e a contradição do PQVT: a "Turma dos irregulares" ...................... 142

8.6) O Selo Ouro de Combate ao Fumo do PQV ................................................. 145

8.7) O "Chão de Fábrica": terceirização e precarização......................................... 149

Capítulo 9: A multiplicidade de modalidades de exercício do poder na realidade brasileira.

Capítulo 10: Programas de Qualidade de Vida para os Trabalhadores enquanto prática de Biopoder e Governamentalidade

Considerações Finais 168

Referências Bibliográficas. 174 
Apresentação 
Esta pesquisa parte de algumas questões suscitadas durante um estágio na área de Recursos Humanos de uma empresa de grande porte, ainda no período de graduação. Durante esta experiência, observei alguns programas institucionais orientados para a melhoria da qualidade de vida dos trabalhadores. Foi possível presenciar a venda de treinamentos prontos para a empresa onde eu estagiava, estruturados de forma rígida e aplicados independentemente da área e do serviço dos trabalhadores que a eles eram submetidos. Acompanhei o fechamento de "pacotes" de treinamentos comportamentais idênticos para núcleos da empresa presentes em diferentes cidades, que atuavam em contextos extremamente diversos ${ }^{1}$.

De forma ampla, a questão que se colocou, a partir desta experiência, foi: "Estes discursos, que vejo direcionados aos trabalhadores, e esta miscelânea de práticas: de onde vêm, a que trabalhador se dirige, a quem interessa este discurso e, principalmente, o que estes trabalhadores pensam e sentem frente estas intervenções organizacionais?"

Juntamente aos treinamentos acompanhados, foi possível o estabelecimento de contato com diferentes empresas de consultoria que atuam nesta área, bem como empresas que atuam enquanto terceirizadas, assumindo uma série de serviços prestados aos funcionários de outras empresas no que diz respeito à promoção de qualidade de vida destes trabalhadores.

Neste sentido, propomos analisar os discursos que aparecem nestes Programas, eventos e consultorias ligados à promoção de Qualidade de Vida do

\footnotetext{
1 Trabalhadores de cidades diferentes e com serviços diferentes eram convidados a realizar os mesmos treinamentos.
} 
Trabalhador e também buscar conhecer qual tipo de racionalidade articula o discurso com sua prática.

Dentre os referenciais teóricos utilizados, encontram-se privilegiadas as noções de Arqueologia, Discurso e Poder em Foucault. 
Capítulo 1: Introdução 
São muitos os autores ${ }^{2}$ que definem e debatem a questão da Qualidade de Vida para os Trabalhadores. Além da diversidade de noções ${ }^{3}$, a multiplicidade de situações do cotidiano organizacional onde estes discursos se engendram em práticas também configura característica fundamental deste campo, tal como descrita nos capítulos seguintes.

A partir desta situação, cabe perguntar, antes de qualquer outra coisa: Como surgiram estes discursos para desenvolver a qualidade de vida dos trabalhadores?

A multiplicidade de conceituações e práticas, apesar de serem muitas vezes incoerentes e mesmo lutarem pela hegemonia entre si, possuem uma história que, caso não explicitada, poderia apresentar a Qualidade de Vida para os Trabalhadores como algo natural, tal como "uma evolução das práticas de gestão".

Porém, partimos de uma discussão inicial acerca do levantamento das possibilidades histórico-discursivas para que a própria questão "Como melhorar a Qualidade de Vida dos trabalhadores?" pudesse, ela mesma, ser formulada. Pode parecer óbvio que seja importante lutar pela Qualidade de Vida para os Trabalhadores, porém, é justamente devido a esta "obviedade" que costumamos esquecer as raízes históricas e interesses ocultos das práticas atuais.

A fim de compreender as inter-relações dos discursos acerca deste tema e, ao mesmo tempo, buscar suas origens e mutações, utilizamos o método arqueológico tal como proposto por Foucault $(1972,1979,1997)$. Este método busca propiciar ao

\footnotetext{
${ }^{2}$ Como veremos no capítulo 5

${ }^{3}$ Preferimos o uso do termo noção ao invés de conceito por entendermos que o primeiro diz respeito a uma definição ampla, enquanto que conceito refere-se a uma definição precisa de algo. No caso do tema da qualidade de vida dos trabalhadores, o modo como os autores tendem a tratar do tema se dá por meio de noções e não de conceitos propriamente ditos.
} 
arqueólogo do saber a distinção entre "camadas de saber que formam o a priori, isto é, as condições para se conhecer ou se falar de algo e para que algo possa ser objeto de conhecimento" (Araújo, 2008, p.38). Esta proposta distingue-se da concepção marxista de ideologia, pois não deseja separar "o falso do verdadeiro", ou mesmo se algo é científico ou não, mas tem como intuito compreender por quais meios tal objeto veio a ser objeto de conhecimento e como tais discursos acerca deste objeto vieram, com o passar dos tempos, a serem tomados enquanto verdade.

Nesta perspectiva, para podermos falar acerca da prática de promoção de Qualidade de Vida no Trabalho enquanto um discurso que possui raízes históricas e se faz presente nos atuais modelos de gestão de pessoas, fez-se necessário retomar os principais modelos de racionalização do trabalho, como o Fordismo, o Taylorismo, o Toyotismo e etc. para podermos compreender as práticas atuais, chamadas de Novos Modelos de Gestão dos Trabalhadores e organizadas nesta pesquisa em torno de três eixos principais: Gestão de Competências, Gestão do Conhecimento e Organizações de Aprendizagem.

A análise das produções acadêmicas acerca da Qualidade de Vida no Trabalho indicou a existência de três matrizes sobre o tema: Matriz Humanista, Matriz Sociotécnica e Matriz da Qualidade Total. Também articulamos autores que, se não constituem uma matriz referencial, por outro lado apresentam uma visão crítica das propostas clássicas acerca do tema e as contextualizam frente outras áreas de saber, como a Psicologia e a Sociologia.

Trabalhar arqueologicamente sobre um conjunto de textos significa ter em mente que, ao mesmo tempo em que estes discursos remetem a um objeto, criam o objeto. Para Foucault, é ingenuidade pensar que um discurso simplesmente remete a um objeto do conhecimento, pois ao discursar, o sujeito do conhecimento se "faz sujeito" sobre este objeto, constituindo-o. Com isso, toda prática de saber constitui também poder.

Nesta pesquisa utilizamos a noção de poder tal como proposta por Foucault (1979). Esta noção de poder disperso, descentralizado e "desenvolvido" enquanto prática disciplinar mostrou-se extremamente pertinente ao possibilitar-nos compreender como, nas atuais práticas de gestão, mescla-se autonomia com disciplina. Por exemplo, a horizontalidade de postos hierárquicos das novas 
modalidades de gestão de pessoas, onde se diminui consideravelmente os níveis de chefia clássicos do fordismo, fez com que o trabalho em equipes horizontalizadas incrementasse enormemente a disciplina entre os trabalhadores.

A Qualidade de Vida para os Trabalhadores, por sua vez, enquanto objeto de conhecimento da medicina, ergologia, psicologia e outras áreas, tem criado um conhecimento que cada vez mais busca disciplinar o trabalhador a aderir a um estilo de vida supostamente melhor (em geral, ligado a esportes competitivos, etc.).

A fim de abordar o tema de forma mais abrangente, o campo de pesquisa, além dos discursos acadêmicos acerca do tema, foi: Um grupo de debates e networking composto por profissionais de Recursos Humanos, entrevista com uma Consultora e ex-funcionária de uma empresa conhecida por seu programa de QVT, o próprio programa de QV para os trabalhadores de uma empresa e entrevistas realizadas com funcionários desta empresa, bem como inserção em campo mediante trabalho etnográfico.

Devido ao propósito de buscar documentar e analisar o desenvolvimento do discurso acerca da qualidade de vida dos trabalhadores, suas práticas e mecanismos disciplinares, foi necessário adotar estilos diferenciados de inserção em campo em cada situação pesquisada. Esta negociação de condições com o campo apresenta, mediante estilos narrativos diferentes, especificidades da pesquisa documental, no caso da análise de escritos sobre o assunto, e especificidades da pesquisa participante no caso do Grupo de RH, por exemplo. Esta preocupação em respeitar o campo e apresentar a dialética do pesquisador que se faz diferentemente sujeito ao pesquisar situações diferentes explica o porquê da "primeira pessoa do singular" estar presente em um capítulo e não em outro, dentre outras características. 
Capítulo 2: Arqueologia, Saber e Poder. 


\section{1) Foucault: A Arqueologia e a constituição do saber-poder}

\section{a) A arqueologia do saber}

Foucault, com seu método genealógico, não pretende substituir a história das idéias e nem simplesmente fornecer um método científico para as ciências humanas (Araújo, 2008). Não possui, principalmente, nenhuma intenção transcendental, ou seja, não busca alguma causa que transcenda ao próprio discurso para explicá-lo de forma causal. Dispensando inicialmente as noções de causalidade, influência e tradição, o arqueólogo do saber também passa a não se deter na questão que diz respeito a se os conteúdos das proposições são verdadeiros ou falsos.

Sem procurar explicar os fatos como se estivesse pairando acima deles, a arqueologia se preocupa em compreender os jogos de verdade.

"A história que busca não é linear, diacrônica, causal. Esse tipo de historicidade pretende encontrar uma razão, um logos por meio do qual se decifraria o sentido da história" (Araújo, 2008, p.7). Em vez de uma história contínua, global e causal, Foucault indaga como, quais arranjos na ordem do saber produziram determinados objetos que uma ciência pode descrever. Neste sentido, procura-se compreender quais objetos são apresentados por determinados discursos.

À semelhança de Kuhn (2006), com sua noção de paradigma, Foucault propõe a noção de epistemes, que são disposições ou configurações de saber. Para Foucault, o discurso não está na dimensão da representação: o discurso não representa algo que existe, simplesmente. Esta seria uma relação dualista, onde, para além do discurso, 
existe uma realidade à parte. Foucault, ao contrário, concebe que os objetos não preexistem ao saber: eles existem como acontecimentos, como aquilo que uma época pôde dizer por causa de certos arranjos entre o discurso e as condições não discursivas.

\footnotetext{
"Silvio Gallo (1995, p. 14), nos diz que a epistème constitui-se por uma determinada ordem e lógica interna que possibilita o conhecimento. A epistème dispõe-se como a base sólida e coerente sobre a qual todo o arcabouço de saber de uma determinada época firma-se. Não obstante, a epistème não pode ser compreendida enquanto sinônimo de saber, ela coloca-se enquanto existência ordenativa imprescindível, como um princípio de ordenação histórica dos saberes anterior à ordem científica estabelecida. A epistème é a ordem própria do saber, sua configuração, bem como a disposição de um determinado saber em uma determinada época." (Hack, 2006, p. 37).
}

A análise arqueológica objetiva, portanto, o saber de uma época e, mais especificamente, as relações que unem as práticas discursivas a que Foucault chamou de epistemes.

\section{b) Os enunciados}

O saber de uma época é constituído por epistemes, sendo que estas comportam práticas discursivas e são formadas por enunciados. Para se chegar a um enunciado, segundo Foucault, não se deve aceitar sem exame crítico as noções de tradição, influência, desenvolvimento, evolução, mentalidade, pois elas pressupõem uma consciência coletiva e uma causalidade a tecer continuamente a história (Araújo, 2008 , p. 59). Criticando o aparecimento de um objeto do conhecimento como algo "esperado" ou simplesmente fruto da "evolução de alguma teoria", o aparecimento de algo como sendo interessante para se elaborar, ao redor dele, toda uma prática de saberes que buscam esquadrinhá-lo, pesquisá-lo e controlá-lo é o objetivo do arqueólogo. Este se preocupa em tentar buscar quais fatores vieram a permitir que tal "pergunta" ou tal "objeto do conhecimento" pudesse vir a ser esboçado. Sem aceitar que uma nova "pergunta a ser respondida" tenha sido simples evolução da história, o arqueólogo busca justamente as descontinuidades da história. 
Existem diversas e diferentes historicidades (estrutura econômica, mentalidade, política etc.) e cada problemática possui seu contexto histórico. Neste sentido, distancia-se do marxismo, pois ao se procurar diferenças, mutações e transformações, implica em uma outra noção que não a de uma história global com movimento dialético de superação de contradições e final redentor: a síntese (Araújo, 2008, p. 60).

A pergunta a ser feita é "como ocorre que tal enunciado apareceu e não outro em seu lugar?".

O enunciado não possui sujeito gramatical nem sujeito lógico: o lugar do sujeito no enunciado é vazio, podendo ser ocupado por sujeitos distintos, conforme a ordem e saber de que provieram.

Acerca do enunciado estabelecido com relação às doenças mentais, Hack (2006, p. 29) afirma:

\footnotetext{
"O médico coloca-se enquanto sujeito do enunciado à medida que se utiliza deste sem necessariamente o ter elaborado. Deste modo, o saber médico coloca-se enquanto enunciado, pois possui um sujeito vacante e seu conteúdo é a objetivação de uma prática discursiva. Assim sendo, a apropriação e utilização de um determinado discurso caberá, sobretudo, a um determinado grupo de indivíduos, os quais possuem o direito de falar, a competência interpretativa e a capacidade de direcionar um dado discurso a decisões, práticas e instituições. 0 discurso, deste modo, configura-se enquanto forma excludente, possibilitando a poucos o direito de proferir a verdade."
}

Deste modo, um objeto não existe antes de circunstâncias que venham a permitir que alguém possa falar dele com eficácia, produtividade e acerto. Agir de outra maneira pode levar o pesquisador do saber sobre a loucura, por exemplo, a considerar que este saber se desenvolveu com a criação dos hospitais para os loucos, por exemplo, deixando de questionar se, antes deste conhecimento (que gerou poder para alguns), havia, por acaso, "algum louco". É neste sentido que, muitas vezes, consideramos que o discurso sobre algum objeto científico apareceu "após" o objeto existir, ou seja, remetia a um objeto que preexistia ao conhecimento científico sobre ele, enquanto que para o arqueólogo o objeto do conhecimento foi criado concomitantemente à elaboração daquele discurso. 
Ao pesquisarmos Programas de Qualidade de Vida para o Trabalhador, não partimos da questão: “Como melhorar a Qualidade de Vida para os Trabalhadores da melhor forma?" ou "Como se desenvolveu esta área de promoção de Qualidade de Vida?". A questão, anterior a estas, é saber como estas perguntas se tornaram legítimas, sem, no entanto, assumir que havia uma demanda dos trabalhadores por melhor qualidade de vida que pudesse ter "evoluído naturalmente" para a elaboração destas questões.

O enunciado engendra uma prática e um saber que constitui poder. A dificuldade aqui, pela qual nos apoiamos em Foucault para não aceitarmos sem crítica a "tradição" de que é "óbvio" melhorar a QVT", é perguntar se esta preocupação surgiu em decorrência de grupos que se colocaram enquanto sujeitos deste enunciado, criando a demanda por Qualidade de Vida aos Trabalhadores ao mesmo tempo em que se "auto-criavam" enquanto resposta a esta pergunta.

Para Machado (2006, p.145-153), o discurso não é um saber que se refere a alguma coisa externa a ele enquanto "objeto", pois este se constitui no próprio momento de sua enunciação. Um exemplo disto é que a loucura não é um fenômeno que existia e ao redor do qual se desenvolveu um campo de conhecimento que a tem por objeto: a Psicopatologia. Ao invés disso, a loucura é que foi construída pelo que se disse dela.

\footnotetext{
${ }^{4}$ Utilizaremos a sigla QVT para designar Qualidade de Vida dos Trabalhadores.
} 


\section{2) Discurso e Poder}

Na Arqueologia do Saber (Foucault, 1972) aparece a noção de que há poder no próprio discurso, sendo que este suscita o desejo de sua posse, seja para servir à simbolização, seja para articular aquilo que não deve ser dito - interdito, portanto.

\section{Foucault afirma que há}

“O regime e os processos de apropriação do discurso pois em nossas sociedades (e em muitas outras provavelmente) a propriedade do discurso - entendido ao mesmo tempo com direito de falar, competência para compreender, acesso imediato e lícito ao corpus dos enunciados já formulados, capacidade, enfim, de investir este discurso em decisões, instituições ou práticas - está reservado de fato (e às vezes de modo regulamentar) a um grupo determinado de indivíduos; nas sociedades burguesas que conhecemos a partir do século $\mathrm{XVI}$, o discurso econômico nunca foi um discurso comum (não menos que o discurso médico ou o discurso literário, ainda que de outra maneira)" (Foucault, 1972, p.90)

O discurso não é neutro, para Foucault, e a prática discursiva relaciona elementos distintos como instituições, técnicas, grupos sociais e discursos diversos. Por obedecer a uma lei da "raridade", pois nem tudo é dito por todos, torna-se alvo de disputa, de luta mesmo e não uma fonte inesgotável de interpretações, fruto da atitude exegética (Araújo, 2008, p. 67).

Segundo Foucault (1972),

“Ele aparece como um bem - finito, limitado, desejável, útil - que tem suas regras de aparição, mas também suas condições de apropriação e de realização; um bem que põe, por conseguinte, a partir de sua existência, (e não simplesmente por suas "aplicações práticas") a questão do poder; um bem que é, por natureza, objeto de uma luta, e de uma luta política." (p. 168)

E também:

"A parte crítica da análise prende-se com os sistemas de envolvimento do discurso; ela visa assinalar e distinguir esses princípios de prescrição, de exclusão, de raridade do discurso." (Foucault, 2006, p. 63) 
Havendo, portanto, poder social, político, econômico, institucional e o poder das práticas discursivas, cabe destacar que, para Foucault, este último não pode ser influenciado pelos outros, proibido socialmente, mascarado, provocando distorções ou ilusões e tendo, portando, que ser denunciado como ideológico. O discurso deve, nesta perspectiva, ser descrito enquanto autônomo, porém, isto não implica em neutralidade ou redução ao elemento puramente lingüístico: "Se a sociedade se apropria do discurso para regrá-lo, como pode ele ser autônomo?” (Araújo, 2008, p. 68).

A arqueologia, enquanto método, limita-se a descrever as formações discursivas, enquanto que a interpretação e crítica destas se faz pelo método genealógico, tido como um complemento do anterior.

"Resumindo, não é a atividade do sujeito do conhecimento que produziria um saber, útil ou arredio ao poder, mas o poder-saber, os processos e as lutas que o atravessam e que o constituem, que determinam as formas e os campos possíveis do conhecimento" (Foucault, 1997 p.27)

Portanto, se a constituição de um campo de saber está atrelada às relações de poder, cabe agora explicitar o que o autor entende por poder. 


\section{3) Poder e Disciplina}

O enfoque genealógico desenvolvido em Vigiar e Punir (Foucault, 1997) permitiu a análise do que Foucault chamou de sociedade disciplinar, que teria fabricado indivíduos "dóceis e úteis". Não se buscou, portanto, a elaboração de uma história das prisões no sentido comum de história (detalhando origens, causas etc.). A preocupação, entretanto, estava direcionada ao problema da individualização, da normalização, da disciplinarização e da formação de saberes e poderes controladores cujo resultado é o homem objeto de saber da medicina, da psicologia, do direito etc.

Desta forma, a sociedade disciplinar foi produzida por técnicas punitivas, mecanismos e dispositivos reguladores e controladores nas escolas, prisões, fábricas, quartéis e hospitais.

Nossa sociedade teria inventado aparelhos para regular os corpos, mas não por meio de poderes massacrantes e de todo visíveis, mas por micropoderes. Longe de abolirem os macropoderes, os micropoderes Ihes dão sustentação e multiplicam seus efeitos.

O poder não é um objeto natural, "uma coisa" aponta Machado (1979), é uma prática social e, como tal, constituída historicamente. Se até então a área da ciência política estudava o poder como atrelado à noção de Estado, Foucault, a partir de evidências de seu material de pesquisa, vê delinear-se uma não sinonímia entre Estado e poder.

\footnotetext{
"seria impossível localizá-la, quer num tipo definido de instituição, quer num aparelho do Estado. Estes recorrem a ela: utilizam-na, valorizam-na ou impõem algumas de suas maneiras de agir. Mas ela mesma, em seus mecanismos e feitos, se situa num nível completamente diferente. Trata-se de alguma maneira de uma microfísica do poder posta em jogo pelos aparelhos e instituições, mas cujo campo de validade se coloca de algum modo entre esses grandes funcionamentos e os próprios corpos com sua materialidade e suas forças" (Foucault, 1997, p. 26)
}

A microfísica do poder, aponta Machado (1979), remete tanto a um deslocamento do espaço de análise quanto do nível em que esta se efetua. O espaço de análise é alterado, pois, da anterior centralidade da figura do Estado, agora são os 
poderes locais os focalizados, enquanto que o nível em que esta análise se efetua passa agora a considerar a investigação dos procedimentos técnicos de poder que realizam um controle detalhado, minucioso do corpo - gestos, atitudes, comportamentos, hábitos e discursos ${ }^{5}$.

Para Foucault:

“A derrubada desses 'micropoderes' não obedece, portanto à lei do tudo ou nada; ele não é adquirido de uma vez por todas por um novo controle dos aparelhos nem por um novo funcionamento ou uma destruição das instituições(...)" (Foucault, 1997, p. 27)

Descentrar o Estado como epicentro de irradiação do poder, entretanto, não significa localizar apenas fora dele sua existência. Não significa, também, dizer que a periferia agora é o centro desta emanação. Machado (1979) continua: "O interessante desta análise é justamente que os poderes não estão localizados em nenhum ponto específico da estrutura social” (p. XIII). Não estando localizados em pontos específicos, funcionam como uma rede de dispositivos a que nada ou ninguém escapa, em que não existe exterior possível.

Esta é a fonte da polêmica onde o poder não mais é visto como sendo "possuído", não há a possibilidade de se apresentar tal como uma propriedade ou mercadoria. O poder, neste sentido, só pode ser exercido. Desta forma, não existem os poderosos e os que não o possuem, pois "o poder" não existe, o que existe são práticas e relações de poder.

Não sendo um objeto, o poder é uma relação, algo que se exerce e se efetua disseminando-se por toda a estrutura social sem privilegiar espaços. Não havendo exterioridade a ele, qualquer resistência se faz de dentro da relação, não podendo ser exercido "de fora". "E como onde há poder há resistência, não existe propriamente o

\footnotetext{
5 Analisar a questão do poder de forma autônoma ao Estado significa partir da perspectiva que uma mudança no âmbito deste não implica em alterações substanciais ao nível capilar onde o poder se engendra. É esta autonomia que o poder tem na periferia do sistema que é levada em consideração. “É que nem o controle, nem a destruição do aparelho de Estado, como muitas vezes se pensa - embora, talvez, cada vez menos - é suficiente para fazer desaparecer ou para transformar, em suas características fundamentais, a rede de poderes que impera em uma sociedade" (Machado, 1979, p. XIII)
} 
lugar de resistência, mas pontos móveis e transitórios que também se distribuem por toda estrutura social." (Machado, 1979, p.XIV). Esta perspectiva já foi utilizada na área de Psicologia do Trabalho por Sato (2002, 2008), onde a diluição do poder em micropoderes e situações relacionais possibilita aos trabalhadores agir de forma a prevenir agravos à sua saúde, bem como utilizar o discurso gerencial para defesa de interesses de classe.

O poder, para Foucault, não pode mais ser assimilado à figura do Estado que o exerce somente mediante repressões e opressões. Ao contrário, o novo tratamento desta temática vincula o poder prioritariamente a uma concepção positiva de ação. 0 poder, portanto, se exerce mais ao dizer como agir, falar e ser, ou seja, se exerce mais na positividade disciplinar de criação de certos sujeitos, do que mediante a repressão de comportamentos e punições.

A relevância desta noção foucaultiana para o estudo de Programas Corporativos acerca da QVT se mostrou de forma ampla ao nos depararmos com a tendência destes em "ensinar" o trabalhador a desenvolver um estilo de vida considerado organizacionalmente como saudável. Neste sentido, percebemos que estas ações institucionais se pautavam pela positividade, ou seja, se mostravam mais interessadas em apresentar aos trabalhadores "modos de ser" valorizados (ser criativo, atento, esbelto, calmo etc.), ao invés de reprimir comportamentos ou atitudes.

“O poder possui uma eficácia produtiva, uma riqueza estratégica, uma positividade. E é justamente esse aspecto que explica o fato de que tem como alvo o corpo humano, não para supliciá-lo, mutilá-lo, mas para aprimorá-lo, adestrá-lo" (Machado, 1979, p. XVI)

Quando caracterizado somente pela sua função repressiva, o poder não está totalmente configurado. Não Ihe interessa mais expulsar os homens da vida social ou impedir o exercício das suas atividades, o objetivo é gerir a vida dos homens, controlálos para viabilizar sua utilização ao máximo e direcionar o desenvolvimento de suas capacidades.

"Objetivo ao mesmo tempo econômico e político: aumento do efeito de seu trabalho, isto é, tornar os homens força de trabalho dando-lhes uma utilidade econômica máxima; diminuição de sua capacidade de revolta, de resistência, de 
luta, de insurreição contra as ordens do poder, neutralização dos efeitos de contra-poder, isto é, tornar os homens dóceis politicamente" (Machado, 1979, p.XVI).

Deetz (1992) afirma que a demonstração explícita e unilateral de autoridade, no meio organizacional, freqüentemente denota mais uma ruptura do sistema de controle nas relações de poder do que a presença deste controle.

É desta forma que a expansão da função panóptica pelo corpo social viabilizou o exercício amplo, intenso e não violento do poder. Segundo Scharamm (1997): “Percebe-se ser mais rentável vigiar que punir: os custos econômicos e políticos são menores e o poder integra-se ao crescimento da própria eficácia produtiva" (p. 1). 
Capítulo 3: Metodologia 


\section{1) O Campo de pesquisa enquanto Campo-Tema}

O estudo dos mecanismos e discursos organizacionais acerca da promoção da Qualidade de Vida aos Trabalhadores constitui um objetivo de pesquisa ligado ao tema citado e não propriamente a algum espaço específico, como uma empresa, uma consultoria ou uma escola teórica da administração, por exemplo. Estudar nas empresas e não propriamente estas empresas foi o intuito. Assim, em termos metodológicos, o estudo buscou acessar lugares nos quais tais mecanismos e discursos se faziam presentes.

Segundo Spink (2003b): “Campo, portanto é o argumento no qual estamos inseridos; argumento este que tem múltiplas faces e materialidades, que acontecem em muitos lugares diferentes" (p. 28).

Estudar a questão da QVT, portanto, envolveu articular as diferentes formas nas quais o fenômeno estudado se apresentava: artigos e livros, eventos, treinamentos, depoimentos de trabalhadores de instituições privadas e de economia mista etc. Todos estes espaços, portanto, configuram campo de pesquisa, tal como apresentado na reflexão de Spink (2003b) acerca de uma perspectiva pósconstrucionista em Psicologia Social.

Frente às possibilidades de se estudar o tema da Qualidade de Vida no Trabalho, buscamos nos pautar também pelas considerações de tratamento rigoroso do material obtido pela pesquisa qualitativa, tal como sugeridos por Becker (1999), Rockwell (1986) e Sato \& Souza (2001), principalmente nas orientações condizentes com a apresentação de trechos relevantes do material (observado ou transcrito) juntamente com a análise, no corpo do texto, de forma a permitir ao leitor que 
visualize a opção analítica do autor para que possa concordar, confrontar ou chegar às suas próprias conclusões.

Nesta pesquisa, não partimos de uma estruturação metodológica prevista em seus detalhes, mas, ao contrário, previmos justamente a contínua negociação da metodologia com o decorrer do trabalho de campo e das possibilidades gradativamente apontadas por ele.

Este fato explica os diferentes estilos narrativos apresentados no decorrer da pesquisa. Enquanto o trabalho analítico com os textos acadêmicos demandava um tipo específico de sujeito-pesquisador, a participação em eventos narrados no capítulo acerca do RH-Group implicou em outra articulação com o campo, mais próxima à da observação participante.

O estilo narrativo das situações, buscando, em alguns momentos, a narração em detalhes de acontecimentos presenciados pelo pesquisador, decorre da necessidade de esquadrinhar os momentos argumentativos do discurso, tal como proposto pela arqueologia foucaultiana.

A proposta de configurar a presença em campo de modo a respeitar as especificidades deste e de descrever os momentos pesquisados de forma detalhada foi o que justamente possibilitou capítulos sobre diferentes empresas e com estilos próprios de comunicar os achados, onde ora o sujeito pesquisador se aproxima da primeira pessoa do singular ao relatar o campo, ora aparece de maneira mais impessoal, como ao apresentar uma entrevista formal com uma consultora.

Desta forma, por exemplo, o capítulo acerca dos discursos documentados sobre a QVT possui uma metodologia sensivelmente diferente da construída junto ao campo propiciado pelo Grupo de RH pesquisado.

Para além destas metodologias negociadas com o campo e própria a cada capítulo, apresentar uma metodologia geral da pesquisa é falar desta plasticidade, das possibilidades desenvolvidas junto às negociações. No limite, se bem que se possa afirmar isso em todos os momentos de qualquer pesquisa, é na metodologia negociada que o campo se apresentou, muitas vezes, mais autor que o próprio pesquisador. 
Primeiramente, pesquisamos o tema da QVT em publicações acadêmicas e em livros destinados ao mercado editorial. Artigos científicos nacionais foram alvo de detalhado estudo e levaram à leitura dos principais artigos internacionais sobre o assunto. Utilizamos também diversas dissertações de mestrado e algumas teses de doutorado, muitas provenientes da área de Engenharia de Produção. Enfim, livros sobre o assunto, principalmente de autores nacionais, contribuíram a esta pesquisa.

Também constituiu campo desta pesquisa uma empresa de economia mista cujo Programa de Qualidade de Vida para os Trabalhadores possui a característica de abranger a toda a comunidade onde a empresa está inserida. Esta empresa possui um Programa global de Qualidade de Vida chamado Viver Feliz. Por ser de grande porte, o pesquisador obteve autorização para pesquisar um departamento específico, de caráter mais administrativo e com muitos trabalhadores de nível universitário em seu quadro. Esta sub-área é chamada de Tec e, no momento da entrada do pesquisador em campo, estava sendo elaborado um programa local de qualidade de vida, evento este que permitiu ao pesquisador acompanhar reuniões e documentos relativos à sua elaboração.

Além da empresa citada, onde a presença em campo se deu na forma de inserção etnográfica, foi realizada uma entrevista com uma consultora autônoma que trabalha com Transição de Carreiras e aborda, junto a seus clientes, questões acerca da qualidade de vida no trabalho destes. Esta consultora é ex-funcionária da área de Recursos Humanos de uma empresa considerada benchmark em QVT, ou seja, é uma empresa tida como referência em Programas que visam a QVT.

Foi possível também estarmos presentes em diversas reuniões de um grupo de profissionais e interessados em práticas de Recursos Humanos que se reúne uma vez por mês, sempre com algum tema e palestrante específico. Escolhemos duas reuniões para apresentar e analisar nesta pesquisa, pois seus temas versavam diretamente sobre o tema da Qualidade de Vida no Trabalho. 


\section{2) Ferramentas teórico-metodológicas: arqueologia do discurso, observação participante e etnografia.}

Conforme explicitado na Introdução, o método de base para a análise de discurso é o método arque-genealógico de Michel Foucault.

A análise do discurso proferido aos trabalhadores visando a Promoção da Qualidade de Vida, portanto, indicava que o era necessário estar presente nos locais onde este discurso era elaborado: livros e artigos acadêmicos; proferido: local de trabalho, eventos específicos do Programa de Qualidade de Vida etc; compreendido: estar próximo aos trabalhadores visando compreender como aquele discurso era interpretado por estes.

Neste sentido, o peso das contribuições teórico-metodológicas variou de acordo com a articulação com o campo onde o tema estava presente.

Ao nos depararmos frente à miscelânea de discursos acadêmicos e outros oriundos de publicações mais próprias ao mercado editorial, utilizamos o método genealógico desenvolvido por Foucault para que fosse possível compreender quais áreas de consenso e de conflito tais discursos configuravam. Inicialmente, o trabalho junto a estes discursos buscou um levantamento sobre a definição e histórico do termo QVT, mas este campo (os textos) não se apresentava de modo inteligível ao pesquisador que buscava apenas informações organizadas e racionalmente dispostas. Os textos acadêmicos se contradiziam, remetiam a diferentes origens e criavam variados "mitos fundadores" do tema. O trabalho junto a estes discursos não foi estabelecido a priori, mas justamente após o contato com estes o pesquisador foi conduzido à arqueologia.

Junto ao Grupo de RH que se reúne mensalmente, a inserção em campo foi negociada no sentido de permitir ao pesquisador participar das reuniões, workshops e dinâmicas de grupo tal como qualquer outro participante. Neste espaço, a postura do pesquisador se caracterizou pela observação participante. Após cada uma destas atividades, foi realizado diário de campo.

Para documentar o discurso e a compreensão dos trabalhadores da empresa ESB acerca dos discursos aos quais eram expostos, utilizamos a descrição etnográfica, 
oriunda da antropologia e utilizada anteriormente em pesquisas de Psicologia do Trabalho e das Organizações (ver especialmente Sato, 1997), consiste em uma imersão no campo para uma descrição densa (Geertz, 1989), visando "documentar o não documentado". Isso implica, no nosso caso, observação e anotação do que acontece quando estamos presentes no ambiente de trabalho, descrição das relações entre as pessoas e do ambiente onde se trabalha, descrição dos trabalhos e sua organização. As conversas e entrevistas junto aos trabalhadores são anotadas e, sempre que possível, gravadas e transcritas. Esse tipo de incursão permite um contato de maneira mais "natural e espontânea", uma vez que não só o pesquisador observa e o pesquisado é observado, mas ambos têm papel ativo na construção do conhecimento. Faz parte também do estudo etnográfico a análise documental dos materiais de divulgação de informações distribuídos no campo de pesquisa.

Segundo Ezpeleta e Rockwell (1986) a descrição etnográfica é um “objeto construído". Para a compreensão dos fenômenos documentados, o pesquisador leva uma perspectiva para o campo, ou seja, não se trata de 'dados' que estão prontos esperando apenas a observação e mensuração; pesquisados e pesquisadores constroem o conhecimento necessário para o desvelamento das "camadas do real".

A empresa ESB possibilitou-nos realizar análise documental com as Atas das Reuniões sobre a elaboração e aprovação do PQV, bem como acesso aos materiais produzidos pela empresa visando disseminar o Programa Corporativo de QV para todos os trabalhadores da ESB.

Tivemos acesso a:

- Duas Atas de Reunião da coordenação da Tec, reuniões estas que versavam sobre a elaboração e aprovação do PQV da Tec;

- Três apresentações em slides, de três diferentes fases da elaboração do Programa;

- Manual Viver Feliz, caderno informativo oficial sobre o Programa Corporativo de Qualidade de Vida da ESB, para trabalhadores, familiares e comunidade;

- Livreto sobre o Código de Ética e Conduta da ESB; 
- Acesso à Intranet Corporativa, uma rede de computadores interna à empresa, destinada somente aos funcionários e contendo informações e material didático para qualificação dos trabalhadores.

O RH-Group permitiu-nos acesso ao material digital utilizado durante as apresentações e workshops, bem como a materiais específicos das empresas descritas nesta pesquisa.

\section{3) Entrevistas}

Somam-se, ao trabalho de campo e à análise documental, algumas entrevistas "mais estruturadas", realizadas com pessoas que fazem parte da instituição, mas não são trabalhadores da área na qual passamos a maior parte do tempo.

A entrevista com a funcionária da Associação dos Trabalhadores da ESB, responsável pela parceria desta instituição com a empresa para a coordenação do Programa de Qualidade de Vida da ESB, por exemplo, foi realizada na Associação, em uma sala específica de reuniões.

Também foram entrevistadas, antes da entrada em campo na ESB, três pessoas que não possuem ligação com a empresa citada:

Uma consultora de $\mathrm{RH}$, que trabalhou muitos anos em uma grande rede de supermercados, foi entrevistada com o objetivo de se conhecer o Programa de Qualidade de Vida desta empresa privada, visando levantar dados para uma possível posterior comparação com as características encontradas no Programa de QV da empresa de capital misto pesquisada. A entrevista foi semi-estruturada, focando na descrição do Programa de QV da empresa onde trabalhava e suas experiências pessoais relativas a esta ação corporativa. A entrevista foi realizada na sala de reuniões de sua atual firma de consultoria.

Esta consultora, por sua vez, indicou uma psicóloga organizacional que prestava serviços para esta empresa, cuja entrevista realizou-se em seu consultório particular e objetivou conhecer o trabalho de uma consultora e realizadora de eventos em QV, bem como as condições de trabalho dentro de uma empresa de mercado. A entrevista 
seguiu o modelo de entrevista semi-estruturada e o roteiro buscou abranger os temas: stress, produtividade/desempenho e saúde do trabalhador.

Foi realizada uma entrevista com uma psicóloga e empresária, dona de uma empresa de Serviços de Atendimento aos Trabalhadores para outras empresas. Esta entrevista objetivou conhecer o mercado de terceirizações na área de serviços de promoção à saúde do trabalhador e também como é realizado este trabalho sem que a empresa tivesse conhecimento do cotidiano das empresas atendidas. Entrevista semiestruturada e focada na descrição dos serviços oferecidos pela empresa, foi realizada nas instalações da empresa durante um "passeio" interno para que pudéssemos conhecer todas as áreas da instituição.

Estas três entrevistas propiciaram conhecer melhor o "mercado" de promoção da qualidade de vida aos trabalhadores e possibilitam também uma possível posterior comparação entre os modelos vistos no mercado privado e na empresa de capital misto.

É importante afirmar que, durante o trabalho de campo, apesar de nos referirmos a algumas "entrevistas" com os trabalhadores, estas não se dão conforme entrevistas estruturadas, mas com características que aproximam estes contados mais à conversas propriamente ditas, de "roteiro aberto", inicialmente com o mínimo de intervenção de modo a facilitar o livre discurso dos entrevistados e, só posteriormente, ocorrendo a introdução dos temas da pesquisa. Nesta estadia em campo, nos inspiramos no modelo de entrevista adotado por Bernardo (2001), sem questões padronizadas e pré-definidas, cuja introdução do tema de pesquisa era realizado somente no caso de não ser abordado de forma espontânea.

Segundo a autora, um modelo que aproxima o método de entrevista da perspectiva etnográfica almejada é a descrição de Hammersley e Atkinson (2001, apud Bernardo, 2001):

\footnotetext{
"A principal diferença entre as entrevistas realizadas por etnógrafos e as entrevistas com questionários não é, como freqüentemente se sugere, que umas sejam 'desestruturadas' e as outras 'estruturadas'. Todas as entrevistas, como qualquer outro tipo de interação social, são estruturadas, tanto pelo investigador como pelo informante. A diferença fundamental está em que umas são entrevistas reflexivas e outras são padronizadas. Os etnógrafos não decidem de antemão as questões que querem formular,
} 
ainda que costumem entrar na entrevista com uma lista de temas dos quais querem falar. Os etnógrafos tampouco se restringem a uma única maneira de indagar. Em diferentes entrevistas, ou em diferentes momentos de uma mesma entrevista, a aproximação a um tema pode ser direta ou indireta, dependendo da função que é buscada" (p.129).

Algumas destas entrevistas foram realizadas em grupo, dependendo da situação com a qual nos deparamos. Conversas com grupo de fumantes, que se aglomeravam em frente da empresa para fumar, foram realizadas no lugar citado, fora da instituição. Houve também contatos com grupos de trabalhadores dentro da empresa, sempre que a configuração do local de trabalho permitia tal dinâmica. Nestas situações, houve anotações detalhadas dos contados com os trabalhadores. Algumas entrevistas individuais foram realizadas na sala de reuniões da $\mathrm{Tec}^{6}$, situação em que o gravador foi utilizado mediante autorização do entrevistado e posterior transcrição de seu conteúdo.

\footnotetext{
${ }^{6}$ A área Tec é uma sub-área do Departamento de Tecnologia da empresa ESB, descrita em pormenores no Capítulo 8.
} 
Capítulo 4: $O$ sujeito do trabalho racionalizado: do cronômetro ao espírito disciplinado 
As práticas observadas sobre a promoção de qualidade de vida no trabalho compõem uma bricolagem de modalidades de gestão e organizações do trabalho, modelos antigos como o fordismo e outros - supostamente - novos, como a gestão por competências. Neste capítulo analisaremos algumas mudanças nestes modelos, privilegiando uma leitura sobre as modalidades de exercício do poder e da disciplina sobre os trabalhadores. Com isso, esperamos contextualizar o cenário atual de gestão de pessoas para discutir posteriormente o quanto estes programas de qualidade de vida não acabam por contribuir e/ou negar as práticas disciplinares enquanto uma nova modalidade de controle.

\section{1) Do Taylorismo ao Modelo Japonês}

Segundo Antunes (2007), a década de 80 presenciou, nos países de capitalismo avançado, profundas transformações no mundo do trabalho, desde suas formas de inserção na estrutura produtiva até as formas de representação sindical e política. Para este autor, as modificações foram tão intensas que pode-se afirmar que a classe-quevive-do-trabalho sofreu a crise mais profunda deste século, atingindo não só sua materialidade, mas com profundas repercussões em sua subjetividade (p. 23) e, no inter relacionamento destes níveis, afetou sua forma de ser.

São diversos os processos produtivos que convivem mutuamente, não se resumindo mais ao Fordismo e ao Taylorismo. Atualmente, o Neofordismo, Neotaylorismo e o pós-fordismo, entre outros, são possibilidades e costumam conviver simultaneamente dentro de uma mesma unidade fabril.

O "cronômetro" e a produção em série e de massa são "substituídos" pela flexibilização da produção, pela "especialização flexível", por novos padrões de busca 
de produtividade e, concomitantemente, por novas formas de adequação da produção à lógica do mercado (Antunes, 2007).

"Ensaiam-se modalidades de desconcentração industrial, buscam-se novos padrões de gestão da força de trabalho, dos quais os Círculos de Controle de Qualidade (CCQs), a 'gestão participativa', a busca da 'Qualidade Total', são expressões visíveis não só no mundo japonês, mas em vários países de capitalismo avançado e do Terceiro Mundo industrializado" (Antunes, 2007, p.

24)

O fordismo vai sendo mesclado ou substituído pelo modelo japonês e as transformações da realidade social do trabalhador abrangem também os direitos do trabalho, vide desregulamentações e flexibilizações.

Acompanhar o desenrolar das práticas gerenciais de racionalização do trabalho é importante para o objetivo desta pesquisa pois fundamenta o cotidiano administrado onde as práticas de promoção da qualidade de vida vão se instalando e, cada vez mais, possuindo um lugar dentre os discursos gerenciais.

Em traços gerais, o fordismo é, fundamentalmente, a forma pela qual a indústria e o processo de trabalho consolidaram-se ao longo deste século (Antunes, 2007). Seus elementos básicos eram dados pela produção em massa, através da linha de montagem e da homogeneidade de produtos; o controle dos tempos e movimentos (pelo chamado "cronômetro" taylorista juntamente com a produção em série fordista); o parcelamento do trabalho e a fragmentação das funções; a separação entre elaboração e execução do processo de trabalho; a existência de centros industriais concentrados, com a conseqüente "invenção" do operário-massa.

Martins (1993) afirma que a introdução de uma maquinaria moderna nas fábricas brasileiras levou ao estabelecimento de normas de contratação impessoais e baseadas na qualificação, ao invés de pessoas conhecidas pelos funcionários como filhos, etc. A impessoalidade das relações de trabalho e a deterioração da autoridade moral antes exercida pelo mestre de ofício levaram à criação de um regime de controle baseado na visão, sendo que o supervisor ficava em um lugar mais alto que os demais trabalhadores, possibilitando observá-los e controlá-los. 
Este modelo de controle baseado na visão ${ }^{7}$, segundo este autor, remetia ao panoptico ao qual Foucault (1997) descreve. Ao relatar o caso da reestruturação da Fábrica de Cerâmica São Caetano, em 1956, Martins(1993) afirma:

"Com umas poucas exceções, estavam as seções instaladas segundo a concepção do panóptico, de que nos fala Foucault. Num lugar estratégico ficava, em plano mais levado, um pequeno escritório envidraçado onde trabalhavam o mestre e seus auxiliares" (Martins, 1993, p. 25).

Apesar de algumas modificações suscitadas por tentativas tais como as da chamada Acumulação Flexível (Antunes, 2007), foi o Modelo Japonês que provocou mudanças intensas, tanto pela revolução técnica que operou na indústria japonesa, quanto pela capacidade de propagação pelo mundo de alguns de seus pontos básicos.

Para Oliveira (2004), descrever o Modelo Japonês em sua totalidade consiste em uma tarefa problemática, pois para abranger suas "novidades", necessitar-se-ia fracionar este sistema decompondo-o em técnicas isoladas e ângulos de análise, o que acabaria por transfigurar a realidade que se queria explicar.

A autora afirma a emergência deste modelo para além da realidade nipônica, a partir da década de 1970, num "pioneirismo que conseguia aliar crescimento continuado da produtividade e reafirmar a subordinação do trabalho na medida em que introduz as divisões internas e a competição no centro do coletivo do trabalho"(p. 10 ), este modelo (também conhecido como toyotismo) ajudou a varrer as posturas classistas como método primordial de luta pela emancipação e confinando o potencial contestatório à parceria na fábrica e ao colaboracionismo político na sociedade.

Idealizado por Taiichi Ohno, então engenheiro da Toyota Motor Co., foram realizados experimentos desfazendo a linha linear de montagem fordista juntamente com modificações da tarefa e da qualificação do homem em seu trabalho. A polivalência do trabalhador, paralelamente à experimentação de técnicas como kanban, Just-in-time, trabalho em equipe, kaisen e as sugestões de "boas idéias" fazem parte deste novo enredo produtivo.

\footnotetext{
${ }^{7}$ Inclusive com a realização de orifícios nas portas dos banheiros para que algum supervisor pudesse, de tempos em tempos, passar pelos sanitários e observar o que os trabalhadores estavam fazendo.
} 
Se o trabalho em posto fixo, realizado pelo trabalhador em uma linha de montagem, encontrou seus limites no fordismo, Ohno (Ohno apud Oliveira 2004) sugere que o trabalho em equipe pode ser desenvolvido tal como realizado nos jogos competitivos de equipe:

\begin{abstract}
“A manufatura também é feita através do trabalho em equipe - não quantas peças foram usinadas ou perfuradas por um operário, mas quantos produtos foram completados pela linha como um todo (...) $O$ trabalho em equipe combinado com outros fatores pode permitir que um time menor vença. $\mathrm{O}$ mesmo é verdadeiro num ambiente de trabalho (...) As coisas não funcionam necessariamente bem no trabalho só porque áreas de responsabilidades foram atribuídas. O trabalho em equipe é essencial” (Ohno, 1997, apud Oliveira, 2004, p.27)
\end{abstract}

Oliveira (2004) cita o exemplo de uma indústria automotiva nos EUA como exemplo da racionalização que está por trás da introdução do trabalho em equipe da Toyota, onde equipes produziam 960 veículos por dia, tendo suas tarefas planejadas em ciclos de 60 segundos e, após serem "aceleradas" para produzir 1.152 veículos por dia (72 veículos por hora), as tarefas passaram a ser definidas em unidades de 50 segundos.

Referindo-se à experiência brasileira, a autora afirma que, apesar "das vantagens" do trabalho em equipe ser melhor visualizado em uma indústria de automóveis, esta modalidade está presente em empresas de diversos segmentos, tais como a Natura, Correios e Telégrafos etc.

Desta forma, a modalidade de controle dos trabalhadores presente no Fordismo, onde a máquina e a linha de produção ditava o ritmo e o supervisor constantemente observava o trabalhador, foi alterado em sua dimensão heteroproduzida para uma nova modalidade onde as equipes passaram a auto-gerenciar a disciplina, internalizando (e claramente intensificando) o controle.

"Eis o team-work - um sistema de máquinas, uma equipe de trabalhadores unidos pela coerção de 'fazer certo na primeira vez' (...) Se não operando com uma técnica de intensificação do trabalho, ou de responsabilização do trabalhador, mas como uma forma de internalizar o controle de uns trabalhadores sobre outros e, até, de permitir a penalização na forma de castigos que uns trabalhadores impõem a outros, caso seu desempenho não 
seja satisfatório. A experiência mais extrema nesse sentido é a verificada numa fábrica no México, onde uma trabalhadora teve de passear com uma faixa de miss faltosa e outra teve de limpar toda a sua seção por faltar uma única vez" (Oliveira, 2004, p. 29)

Esta modalidade de produção calcada no trabalho em equipe, para a autora, contribui de forma inteiramente nova para fazer com que a solidariedade de classe não esteja presente e seja soterrada pela organização dos trabalhadores em torno da competitividade.

Segundo Hirata (1991), o papel dos coletivos de base precisa ser pensado em sua dupla forma de coerção. Primeiro, pois o exercício do coletivo de base é severamente controlado. Apesar de possuírem um poder legítimo de participação na inovação, tudo concorre para a transformação deste direito em dever. Segundo esta autora, estes grupos de melhoria e inovação, que abrangem todos os funcionários, possui um objetivo institucional inicial: a identificação dos trabalhadores com os objetivos da empresa e o registro e análise dos comportamentos de oposição.

Hirata (1991) prossegue, afirmando que a segunda forma de coerção característica deste modelo japonês é o fato do indivíduo ser, de fato, controlado pelo coletivo de base, pois se estes coletivos são o lugar de acolhimento e participação, "a forma estritamente pessoal de individualidade deve apagar-se: deve adequar-se à necessidade do coletivo" (p.182).

O Controle de Qualidade, conceito importado pelo Centro de Produtividade do Japão em 1950, oriundo dos Estados Unidos, foi conjugado com o conceito de pequenos grupos e de grupos de gestão operária, já existentes nas fábricas japonesas (Oliveira, 2004, p.49), e se revelou como instrumento mais eficaz de integração/subordinação dos trabalhadores na empresa. Após 1960, beneficiando-se também da campanha "zero-defeito", realizada pela indústria de mísseis americana, foi, após algumas modificações, aplicada pela Nippon Electric Co., assumindo a forma atual de Círculos de Qualidade.

Originalmente, os Círculos de Qualidade têm a finalidade de compatibilizar a eficiência da empresa com a humanidade do trabalhador e buscariam, segundo a autora, promover total comprometimento com a empresa. 
Apesar desta "missão", a prática dos CCQs revelou que a prevalência do crescimento constante da produção instrumentalizou "o coração e a alma" do trabalhador como elementos ativos na guerra da concorrência.

Antunes (2007, p. 37), citando Bem Watanabe, que durante trinta anos atuou no movimento sindical japonês, levanta uma questão constantemente esquecida sobre os CCQs:

"O CCQ foi desenvolvido no Japão por gerentes de empresas, a partir dos anos 50, junto com o toyotismo. No sistema Toyota, os engenheiros do chão de fábrica deixam de ter um papel estratégico e a produção é controlada por grupos de trabalhadores. A empresa investe muito em treinamento, participação e sugestões para melhorar a qualidade e a produtividade. 0 controle de qualidade é apenas uma parte do CCQ (...) e inclui-se um outro elemento: a eliminação da organização autônoma dos trabalhadores. (...) A Toyota trabalha com grupos de oito trabalhadores... Se apenas um deles falha, o grupo perde o aumento, portanto este último garante a produtividade assumindo o papel que antes era da chefia. O mesmo tipo de controle é feito sobre o absenteísmo" (Watanabe, 1993, apud Antunes, 2007)

Bernardo (2006), em pesquisa realizada com trabalhadores de duas montadoras de veículos de origem japonesa, afirma que a obrigatoriedade em participar é uma realidade dos funcionários.

\footnotetext{
"Notamos, assim, um enorme contraste entre o discurso da igualdade e de valorização do trabalhador, por um lado, e a imposição da participação em atividades específicas de acordo com as regras pré-estabelecidas, por outro" (Bernardo, 2006, p. 95)
}

Segundo a autora, cada uma das filiais japonesas utiliza uma nomenclatura própria para definir suas propostas "participativas", porém ambas as empresas utilizam preceitos do modelo japonês, segundo os relatos dos trabalhadores entrevistados. Estes seriam de dois tipos:

\footnotetext{
"o primeiro dizendo respeito à elaboração de sugestões individuais, que envolveriam aspectos qualitativos e quantitativos relacionados à produção e à segurança. $O$ outro se dá mediante uma competição anual entre 'grupos de
} 
melhoria', na qual os trabalhadores se reúnem para desenvolver projetos mais elaborados." (Bernardo, 2006, p. 95)

Contrariamente aos trabalhadores especializados no taylorismo, o toyotismo implicou em trabalhadores multifuncionais (Coriat, 1994), modificação acompanhada pela horizontalização da estrutura gerencial que antes era extremamente verticalizada. Esta horizontalidade possui, nos CCQs, o momento de "estarem em situação de igualdade", pois todos podem opinar e exercer a criatividade. Porém, a obrigatoriedade da participação e o fato de não poderem opinar sobre o que será produzido implica em abranger apenas parcialmente as históricas bandeiras de luta sindical e, como Oliveira (2004) afirma, contribuindo para desorganizar trabalhadores.

"O estranhamento próprio do Toyotismo é aquele dado pelo envolvimento cooptado que possibilita ao capital apropriar-se do saber e do fazer do trabalho. Este, na lógica da integração toyotista, deve pensar e agir para o capital, para a produtividade, sob a aparência da eliminação efetiva do fosso existente entre elaboração e execução no processo de trabalho." (Antunes, 1995, p. 34) 


\section{2) Novos Modelos de Gestão de Pessoas nas Empresas}

As práticas corporativas que visam à promoção de qualidade de vida aos seus trabalhadores estão inseridas em um contexto discursivo moderno de gestão. Dentre diversos autores, Limongi-França (2007), por exemplo, fala da importância em se desenvolver, nos gestores e executivos, a competência gestão de qualidade de vida, ou seja, apresenta este tema organicamente vinculado à chamada Gestão por Competências. Fleury e Fleury (2006), ao apresentarem a importância do trabalhador desenvolver modos de saber-ser; saber agir e saber comprometer-se, desenvolvem o argumento de uma nova subjetividade no trabalho. Devido ao fato das intervenções organizacionais para a promoção de qualidade de vida descritas neste trabalho se apresentarem dirigidas notadamente a estes trabalhadores do dito mundo do trabalho imaterial (Gorz, 2005), apresentaremos algumas das principais características destes modos de gestão que fornecem o contexto discursivo para as práticas pesquisadas.

Diversos são os autores que buscam oferecer análises conjunturais do momento pelo qual passamos. Dentre estes, destaca-se Peter Drucker e sua concepção acerca da Era do Conhecimento, preconizando, já em 1959, as transformações que estariam por vir. Porém é a partir dos anos 90 que o assunto passou a ser divulgado internacionalmente e discutido em universidades americanas, como o MIT, Harvard e Columbia, por exemplo. Nestas instituições, dava-se início aos "estudos de caso", onde cursos de pós-graduação das universidades americanas empenhavam-se em pesquisar as características das empresas que estavam sobrevivendo à crise econômica do final da década de 1980.

Sobre os autores que se destacam desde então, optamos por apresentá-los segundo a divisão utilizada por Brito (2005), articulando-os em três eixos principais: Eixo Gestão de Competências, cuja principal contribuição refere-se à construção de um foco estratégico orientador das ações da empresa; Eixo Gestão do Conhecimento, que se refere ao gerenciamento; e Eixo Organizações de Aprendizagem, que trabalha as interações entre os sujeitos e a mudança da cultura organizacional (p.57). 


\subsection{1) Eixo Gestão por Competências}

O Eixo Gestão por Competências é inaugurado por Prahalad e Hamel com um artigo acerca das Competências Essenciais (The Core Competence of The Corporation, 1990) na Harvard Bussiness Review e desenvolvido posteriormente no livro Competindo pelo Futuro (Prahalad e Hamel, 1995).

"The most powerful way to prevail in global competition is still invisible to many companies. During the 1980s, top executives were judged on their ability to restructure, declutter, and delayer their corporations. In the 1990s, they'll be judged on their ability to identify, cultivate, and exploit the core competencies that make growth possible-indeed, they'll have to rethink the concept of the corporation itself." (Prahalad e Hamel, 1990, p.3)

Neste artigo, os autores defendem que o básico da estratégia empresarial é o gerenciamento da "competência essencial", ou seja, a combinação de tecnologias individuais e habilidades de produção que servem de base a uma infinidade de linhas de produtos em uma empresa.

Para os autores, qualquer empresa que queira captar uma fatia importante dos lucros dos mercados de amanhã precisa desenvolver as competências que serão necessárias no futuro. Para Prahalad e Hamel (1995), "uma competência essencial é um conjunto de habilidades e tecnologias que permite a uma empresa oferecer um determinado benefício ao cliente" (p.4). Citam o exemplo da Sony, que tomou como fator decisivo o "tamanho de bolso" de seus produtos e a competência essencial passou a ser a miniaturização. Na Federal Express, o benefício seria a entrega rápida, levando a conceber a competência essencial da empresa como a própria gestão de logística.

A competência, para gerar competitividade, precisa ser articulada de forma a ser "específica" da organização e, para tanto, precisa passar em três testes: valor

\footnotetext{
${ }^{8}$ A maneira mais eficiente de prevalecer na concorrência global é ainda invisível para muitas empresas. Durante a década de 80, os altos executivos foram julgados na sua capacidade para reestruturar, reorganizar e horizontalizar suas corporações. Na década de 90, serão julgados na sua capacidade para identificar, cultivar e explorar as principais competências que possibilitam o crescimento - na verdade, eles terão que repensar o próprio conceito de corporação. (Tradução nossa).
} 
percebido pelo cliente; diferenciação entre concorrentes e capacidade de expansão (Brito, 2005, p. 59).

Para os autores da Gestão por Competências, as competências essenciais precisam ser o principal assunto da estratégia corporativa. A alta gerência precisa saber se as atuais competências da empresa estão sendo lentamente enfraquecidas ou fortalecidas e deve ser capaz de identificar um negócio que precisa de investimento e quais competências precisam ser mantidas.

Segundo Brito (2005): “Dentro desta perspectiva, uma empresa deve ser vista não apenas como um portfólio de produtos ou serviços, mas também como um portfólio de competências" (p.59).

Estando na pauta do dia, a gestão por competências reorganiza o cotidiano da organização que a adota de forma a buscar que as competências essenciais criem raízes dentro da empresa: toda a equipe de gerência precisa compreender detalhadamente e participar das tarefas fundamentais da administração das competências, tais como identificar as competências essenciais existentes, definir uma agenda de aquisição de competências essenciais e as desenvolver e também defender a liderança das competências essenciais da empresa no mercado.

\footnotetext{
"O objetivo da gestão por competência não é impor uma competência específica à organização através de mudanças estruturais, mas colocar a perspectiva dentro da cabeça de cada gerente e funcionário. Isso significa estabelecer um processo de participação profunda para identificação das competências essenciais, envolver as unidades estratégicas de negócios no processo de desenvolvimento de uma arquitetura estratégica (...)" (Brito, 2005, p.60).
}

Esta autora afirma que a grande diferença entre os antigos Planos de Cargos e Funções Especializadas e o Perfil de Competência Profissional é que os primeiros detinham-se prioritariamente no conhecimento especializado, adquiridos pelo trabalhador de forma "isolada" da organização, e tinha a noção de "posto fixo de trabalho", sendo este especializado e rígido, enquanto que, na segunda concepção, o funcionário tem sua trajetória profissional construída de acordo com os interesses da empresa e se situa onde for necessário (tal como um Consultor Interno trabalhando em locais variados). Conclui: "Em outras palavras o Perfil de Competência Profissional, 
que se refere ao indivíduo, surge para atender as necessidades de flexibilização da organização e de exploração máxima do potencial e talento dos empregados" (p.61).

\begin{abstract}
"No modelo das competências o controle da força de trabalho se expressa através de estratégias de ressocialização e aculturação pela conformação da subjetividade do trabalhador. A ênfase na identificação dos interesses de patrões e empregados - que se convertem em uma comunidade social de colaboradores -; a autogestão pela internalização da disciplina; o controle exercido sobre os trabalhadores por seus próprios colegas no trabalho em equipe e a sobrevalorização de aspectos atitudinais (o saber-ser) conferem ao modelo das competências a possibilidade de um controle menos formalizado e mais difuso sobre a força de trabalho, evitando-se as resistências e os conflitos." (Deluiz, 2001, p. 14)
\end{abstract}

Deluiz (2001) ressalta ainda o deslocamento da concepção clássica de qualificação profissional para o de competências profissionais. Enquanto o modelo tradicional assentava-se em saberes técnicos e explícitos do trabalhador, priorizava-se a educação escolar, formação técnica e experiência profissional. Na gestão por competências não importa somente os requisitos tradicionais de qualificação profissional, mas tão importante ou mais é a capacidade de mobilização destes recursos para interesse da empresa.

Se, por um lado, o modelo das competências confere maior valorização de saberes tácitos e não comprovados profissionalmente, como, por exemplo, uma mulher afastada do mercado de trabalho por anos para cuidar dos filhos que agora pode apresentar em seu "portfólio pessoal" a competência de gerir um lar com recursos escassos e cuidar da educação de infantes, por outro, esta concepção (e as entrevistas de emprego deste modelo) adentra a vida do trabalhador com uma profundidade de detalhes nunca antes vista. Os hobbies, os tipos de esportes preferidos (se de competição ou não, etc.), as viagens e tudo o mais que possa ser instrumentalizado pela empresa passa a ser do interesse desta.

Os métodos de avaliação por competências, utilizados para avaliar a evolução do trabalhador com referência às competências escolhidas pela empresa, atribui pontos maiores aos trabalhadores que, em suas horas vagas, dedicaram-se a desenvolver competências de interesse da empresa. Por exemplo, dependendo da competência essencial determinada pela empresa, alguém que optou por fazer 
natação poderá ser preterido à uma promoção mediante alguém que tenha escolhido um esporte que envolva competição em termos de equipe, como o futebol. Os livros que o trabalhador tenha lido também são contabilizados e pontuados de acordo com sua utilidade para a empresa.

Levando em consideração que o aumento de empregabilidade e a manutenção da empresa, bem como as promoções, são articulados enquanto reforço, a gestão por competências apresenta-se tal como um método disciplinar que busca envolver ao máximo a participação do trabalhador na própria dinâmica de tornar-se cada vez mais interessante e útil para a empresa e, principalmente, intensificar, no trabalhador, um sentimento de mostrar que está "se enriquecendo" nestas competências.

O foco em características absolutamente pessoais e de caráter subjetivo apresenta um novo modelo de gestão que escolhe seu trabalhador tendo como base uma "radiografia psicológica". A disciplina atinge, como veremos adiante, uma penetração nos meandros do sujeito que nunca havia sido realizada. As diferenças entre os sujeitos, ao serem punidas com a não-bonificação, promovem uma valorização moral dos atributos da personalidade. Desta forma, ser "líder" passa, em muitas corporações, a ser sinônimo de profissional saudável, adequado. Ao trabalhador que questiona, fica-lhe resguardada a condição de "sujeito sem próatividade". Esta discussão é pertinente ao estudo do tema da promoção de qualidade de vida no trabalho, pois na medida em que verificamos ações organizacionais direcionadas para a saúde, porém com eventos para estimular a criatividade e liderança nos trabalhadores, constatamos uma associação simbólica entre as competências tidas pela empresa como essenciais e as definições de saúde que subsidiam tais programas.

\subsection{2) Eixo Gestão do Conhecimento}

Enquanto Hamel e Prahalad estudavam as condições básicas da gestão estratégica das competências essenciais das organizações, outro grupo reunido pela Harvard Business Review ampliava a discussão da projeção de novos comportamentos e novos modelos de gerenciamento. Este grupo, liderado por Drucker, afirmava que o primordial para a "nova organização" era o aprendizado organizacional, resumido na 
decodificação da lógica dos negócios para a concretização de mudanças que melhorem o desempenho econômico da empresa (Drucker, 1995).

Brito (2005) resume bem a proposta deste grupo: "As novas empresas seriam organizações baseadas em informações, ou seja, organizações que transformam dados em informação e informação em conhecimento." (p. 82).

Nestes termos, os "dados" seriam: simples observações sobre o estado do mundo, facilmente estruturados e obtidos por máquinas, freqüentemente quantificados e facilmente transferidos. A "informação" seria o dado investido de relevância e propósito, o que requer unidade de análise, exigindo consenso em relação ao significado e exige, necessariamente, a mediação humana. O "conhecimento", por fim, como a informação valiosa da mente humana, pois é contextualizada, refletida, sintetizada e é de difícil estruturação, transferência e captura em máquinas, pois freqüentemente é tácito:

"conhecimento é a informação mais valiosa, mais difícil de gerenciar. É valiosa precisamente porque alguém deu à informação um contexto, um significado, uma interpretação; alguém refletiu sobre o conhecimento, acrescentou a ele sua própria sabedoria, considerou suas implicações mais amplas" (Davenport, 2002, p.19)

As organizações baseadas em informação exigiriam muitos especialistas, porém, especialistas diferentes daqueles gerenciados pelo sistema taylorista, pois, além de se concentrarem nas atividades operacionais e não na sede corporativa, estes profissionais devem saber (Drucker, 2000) articular a sua área de conhecimento com outras áreas, com a empresa como um todo e com a realidade mais ampla.

As organizações baseadas em conhecimento, segundo Brito (2005), envolveriam mais cortes de pessoal, visto que somente certos núcleos seriam mantidos, como "concepção e desenvolvimento de políticas e estratégias, assessoria jurídica, relações públicas e assuntos trabalhistas" (p. 83), enquanto que os trabalhadores "sem atribuições operacionais", que assessoram, orientam ou coordenam, diminuiria de forma drástica. Neste caso, o grande contingente de pessoas capacitadas estaria localizado na atividade fim da empresa onde são realizados os negócios. 
Ao contrário da "antiga mão-de-obra" que realizava seu trabalho de acordo com instruções recebidas, na organização baseada em informações o conhecimento se situaria na base, operacionalizado por especialistas que executam e gerenciam-se a si próprios.

Por ser realizada em times, e não mais em linhas de produção, e pela necessidade de auto-gerenciamento das atividades, segundo Drucker, exigir-se-á maior autodisciplina e ênfase ainda mais intensa na responsabilidade individual pelos relacionamentos e pelas comunicações (Drucker, 2000). Aqui, vislumbramos o discurso deste autor acerca da necessidade de intensificação da disciplina internalizada.

\footnotetext{
"As organizações baseadas em conhecimento demandam objetivos nítidos, simples e comuns que se traduzem em ações específicas. Como os 'participantes' de uma organização baseada em conhecimento são especialistas, ninguém pode dizer-lhes como executar o trabalho. Por conseguinte, a empresa baseada em informações deve ser estruturada em torno de metas que definam com clareza as expectativas de desempenho gerencial para toda a organização, assim como para cada parte e cada especialista, e a partir do feedback organizado que compara os resultados efetivos com essas expectativas de desempenho, de modo que cada membro seja capaz de exercer o autocontrole" (Brito, 2005, p.84, grifos nossos.)
}

A Gestão do Conhecimento, tendo como expoentes Nonaka e Takeuchi, afirmava a necessidade específica desta época de se fazer com que o conhecimento produzido na empresa seja identificado, gerenciado e mantido na organização, ou seja, retido de forma independente de quem o produziu.

Tendo como base para sua argumentação a "tradição intelectual japonesa" que, segundo os autores, não cinde corpo e mente, homem e natureza e eu e outro, propõem uma "Teoria da Criação do Conhecimento Organizacional". Explicitando a "unidade do eu e do outro" como manifestada no "ideal de vida japonês [que] é existir entre os outros harmoniosamente como um eu coletivo" (Nonaka e Takeuchi, 1997, apud Brito, 2005, p.87), estes autores dão início à empreitada de teorizar uma metodologia que torne viável "coletivizar" o saber do trabalhador com seus colegas e com a empresa. A busca do "eu coletivo" direcionaria o trabalhador à radicalização da idéia de sentir-se fazendo parte da empresa. Neste sentido, qualquer atitude de oposição à corporação, seus valores ou ideais deve ser sentido pelo funcionário como 
uma auto-flagelação, ao mesmo tempo que esta fragmentação do eu junto à coletividade minimiza a possibilidade de virem à tona até mesmo as estratégias coletivas de defesa, tal como proposto por Dejours (1994), pois mesmo estas demandam a existência de indivíduos.

Segundo Brito (2005): “A gestão do conhecimento, portanto, teria como principal desafio a aquisição e transferência do conhecimento pessoal do trabalhador (tácito) e do conhecimento declarativo (explícito) num processo de transformação interativa e em espiral" (p.88).

A Teoria da Criação do Conhecimento Organizacional, formulada por Nonaka e Takeuchi, prevê cinco fases para o processo de criação do conhecimento organizacional:

- 1. Compartilhamento do conhecimento tácito

- 2. Criação de conceitos

- 3. Justificação dos conceitos

- 4. Construção de um protótipo de organização

- Difusão interativa do conhecimento

Esta "Gestão do Conhecimento" não seria, portanto, a gestão de uma empresa que se apresenta como um portfólio de conhecimentos e saberes, mas justamente a gestão do conhecimento dos seus trabalhadores de forma a absorvê-lo e integrá-lo ao capital intelectual da empresa.

\subsection{3) Eixo Organizações de Aprendizagem}

Peter Senge, então diretor do Centro de Aprendizado Organizacional da Sloan School Management do Instituto Tecnológico do Massachusetts - MIT, em seu livro A Quinta Disciplina (1998) apresenta a necessidade das empresas em "aprenderem a aprender" (Senge, 1998).

A proposta principal deste autor é desenvolver no trabalhador, de forma direcionada para os interesses da empresa, dimensões intelectuais, emocionais e espirituais até então desprezadas no campo da administração. Para tanto, é necessário o desenvolvimento de cinco disciplinas fundamentais para o aprendizado organizacional: 
- Domínio Pessoal

- Modelos Mentais

- Objetivo Comum (visão compartilhada)

- Aprendizado em Grupo

- Raciocínio Sistêmico (quinta disciplina)

O Domínio pessoal, para Senge, é a base espiritual da organização de aprendizagem. O objetivo é esclarecer e aprofundar continuamente o objetivo pessoal para nele direcionar todas as energias. Senge afirma dois momentos do domínio pessoal:

- Deve-se esclarecer continuamente o que é importante para a pessoa

- Deve-se aprender continuamente a entender a realidade do momento

Estes são os ensinamentos para focar o trabalhador em algo que o faça motivar-se a continuar não só no trabalho, mas na vida. O Domínio Pessoal tem como objetivo fazer o trabalhador se conscientizar dos seus desejos, valores e metas, de forma a catalisar este interesse em prol dos objetivos da empresa. Na prática, significa que a empresa, após tomar conhecimento das ambições íntimas dos empregados, busque "casar interesses" caso possível, como, por exemplo, usar um trabalhador que sonhe viajar para algum lugar justamente na hora onde uma viagem para este lugar precise ser realizada.

Para esta primeira disciplina efetuar-se, portanto, é necessário que o trabalhador exponha sua intimidade, seus desejos e temores, para que a organização possa "casar" interesses.

A segunda disciplina, configurada como Modelos Mentais, diz respeito às idéias profundamente arraigadas, generalizações e pré-conceitos que as pessoas utilizam para se locomover durante o cotidiano.

Nesta disciplina, a palavra de ordem é promover um modelo de gestão que leve em conta a diferença de modelos mentais dos trabalhadores de forma a não mais buscar o consenso sobre questões importantes, mas, ao invés disso, buscar promover 
o enriquecimento do debate utilizando-se dos diferentes modos dos funcionários de enxergar a realidade.

Senge (1998) cita o exemplo da Hanover, onde foi implantada a proposta de "melhorar os modelos mentais em todos os níveis da organização" (p.3).

A terceira disciplina, chamada de Objetivo Comum (ou Visão Compartilhada) é justamente o objetivo da organização. Esta visão em comum daria, segundo Senge, um sentimento de coletividade que proporcionaria o foco e a energia necessária para a aprendizagem.

Segundo o autor, em uma empresa, um objetivo comum muda a relação das pessoas com a companhia. Não é mais a "empresa deles" e passa a ser a "nossa empresa". Senge ressalta que somente pessoas conscientes de seus objetivos pessoais podem estar preparadas para assumirem uma proposta maior em concordância com seus próprios interesses, ou seja, se a primeira disciplina não for devidamente desenvolvida, o sujeito não poderá "vasculhar seus interesses" de forma a cruzar informações: qual objetivo pessoal está em concordância com o objetivo comum da empresa.

A dimensão pessoal trabalhada pela terceira disciplina é que vai determinar o grau de mudança de atitude do trabalhador junto à empresa. Para Senge, existem muitas atitudes possíveis em relação a um objetivo: Comprometimento, Participação, obediência genuína, obediência formal, desobediência e apatia. Para a Organização de Aprendizagem, não cabe a obediência, é necessário o comprometimento. 0 comprometido não agiria de acordo com a regra do jogo, pois, se elas forem um estorvo para o sucesso, ele as mudará. Para Senge, um funcionário obediente, "seguidor das regras", não basta.

A quarta disciplina, Aprendizagem em Grupo, busca fazer com que indivíduos que tenham "se conhecido melhor" na primeira disciplina, coordenado objetivos e se comprometido com a missão da empresa, consigam, enfim, trabalhar juntos em equipes. Aqui, a máxima da psicologia grupal volta à tona: o grupo deve produzir mais que a soma da produtividade dos indivíduos tomados isoladamente. Sugerindo a aplicação dos membros de um grupo em ações como diálogos e debates, mediadas por um orientador, Senge espera que propostas inovadoras surjam de forma que nunca aconteceria de forma independente. 
A quinta disciplina vai além do intuito das anteriores. Nesta proposta, Senge espera que os participantes operem uma mudança de mentalidade, o que significa que realidade deve ser tomada enquanto um processo onde "o todo pode ser maior que as partes", integrando as outras disciplinas.

Haveria, portanto, uma "mudança de paradigma" levando o trabalhador a perceber-se como parte da empresa e pensando "junto" com ela. Novamente, temos aqui, como objetivo final, a fragmentação da individualidade perante a figura da empresa. Ao retomar a idéia de que o todo pode ser maior que a soma de suas partes, neste contexto específico, retomamos a idéia de uma empresa cujo peso supere a importância dos micro-cosmos presentes em cada cotidiano dentro desta organização.

Senge, autor chave deste discurso gerencial, não por acaso utiliza a palavra Discipline para se referir a cada dimensão onde a organização deve atuar junto ao sujeito. Nesta modalidade de controle absolutamente internalizada, que pede não só obediência, mas comprometimento, percebemos a imersão total da socialização no trabalho como uma faceta do poder disciplinar (Foucault, 1997). Como veremos adiante, a Organização de Aprendizagem busca fazer o trabalhador aprender a ser um sujeito específico para esta organização. 


\section{3) Da imaterialidade do trabalho e suas transformações}

"Os colaboradores da empresa fazem parte do seu capital (...). Sua motivação, sua competência, sua capacidade de inovação e sua preocupação com os desejos da clientela constituem a matéria primeira dos serviços inovadores (...). Seu comportamento, sua aptidão social e emocional têm um peso crescente na avaliação de seu trabalho (...). Este não mais será calculado pelo número de horas de presença, mas sobre a base dos objetivos atingidos e da qualidade dos resultados. Eles são empreendedores." ${ }^{\prime 9}$

Esta citação, de Norbert Bensel, então diretor de recursos humanos da DaimlerChrysler em 2001, nos apresenta os "novos trabalhadores" aos quais as empresas afirmam precisar se voltar para manterem-se nos negócios. Chamados agora de "colaboradores", são alvos da preocupação executiva acerca de tudo aquilo que pode ser aproveitado para fortalecer o negócio: motivação, competência, capacidade de inovação, preocupação com a clientela, comportamento, aptidão social e emocional etc.

Dentre as medidas organizacionais para "desenvolver" tais características e ainda buscar equacionar a sanidade dos trabalhadores com esta empresa moderna que transcende o local físico e as horas combinadas para o trabalho, vemos consolidarse um novo mercado focado na promoção da qualidade de vida no trabalho.

O termo Qualidade de Vida no Trabalho, longe de possuir uma definição passível de acordo entre os estudiosos da área, possui, porém, presença garantida em quase todos os discursos que apresentam as características da "Empresa Moderna", seja num contexto fordista ou toyotista, seja nas empresas que se definem como oriundas da "Sociedade do Conhecimento", a tão alardeada "Sociedade pós-industrial" (Limongi-França, 2007).

Pesquisar diferentes espaços onde a Qualidade de Vida no Trabalho era articulada, discursada, vendida e implementada puderam fornecer os contornos deste fenômeno organizacional, desde o território acadêmico, onde dissertações e teses buscam compreender e enriquecer o tema, consultorias que vendem eventos e

\footnotetext{
${ }^{9}$ Norbert Bensel, “Arbeitszeit, Weiterbildung, Lebenszeit. Neue Konzepte”, comunicação ao congress internacional Gut zu Wissen. Links zur Wissensgesellschaft, Berlim, 4-6 de maio de 2001, apud Gorz, A. (2005), O Imaterial: Conhecimento, Valor e Capital. São Paulo: Annablume.
} 
"soluções" em qualidade de vida no trabalho, chegando até o cotidiano de uma empresa que busca fornecer aos seus funcionários o "melhor que se pode comprar" em termos de QVT.

Cada um destes espaços, por sua vez, possui características próprias, interesses e modos específicos de sobreviver. Quando observados de perto, as consultorias parecem não dialogar com os livros sobre o assunto, bem como o cotidiano dos trabalhadores da empresa pesquisada parece não corresponder ao mundo no qual as consultorias julgam viver.

Para se compreender os fenômenos observados no campo da pesquisa, foi necessário dar alguns "passos para trás" e buscar visualizar como os espaços pesquisados se articulavam. Após muitos e muitos passos do que se esperava, a análise conjuntural realizada foi mostrando como o mundo do trabalho pensado em termos de "trabalho imaterial" e "sociedade do conhecimento" permitiam que se integrassem os diferentes materiais do trabalho de campo.

Os discursos e práticas observados, por vezes conflitantes, puderam afinal ser reunidos sobre o viés de uma sociedade pós-moderna, congregando a multiplicidade encontrada.

\subsection{1) Sobre o discurso pós-moderno acerca do trabalho.}

É inegável que atravessamos um período onde coexistem muitos modos de organização do trabalho. Segundo Gorz (2005), o capitalismo moderno, centrado sobre a valorização de grandes massas de capital fixo material é cada vez mais rapidamente substituído por um capitalismo pós-moderno centrado na valorização de um capital dito imaterial, qualificado também de "capital humano", "capital conhecimento" ou "capital inteligência" (p. 15). O trabalho complexo vem substituir a antiga fonte do valor, o trabalho abstrato simples. O trabalho imaterial, por sua natureza, necessita de novos padrões de medida, visto que a mensuração por unidades de produtos em unidades de tempo não mais se aplica.

A noção de "trabalho imaterial" está relacionada à de "ativo intangível". Enquanto o trabalho material cria valores concretos, produtos e bens tangíveis, o trabalho imaterial cria os "ativos intangíveis" que, segundo Sveiby (1997) são, por 
exemplo: "a competência do funcionário; a estrutura interna, que consiste nas patentes, relações com os clientes e fornecedores e a imagem da organização". Para este autor, o valor dos ativos intangíveis para uma empresa pode ser obtido considerando a diferença entre o valor de mercado de uma empresa de capital aberto e seu valor contábil líquido oficial.

Ao situar o signo da empresa como sendo o principal valor, e não a sua materialidade, este autor se coaduna com a configuração de discurso pós-moderno tal como concebido por Lipovetsky (2004).

A citação inicial de Norbert Bensel chama a atenção não por tratar de conhecimentos, nem de qualificações profissionais, mas por falar das qualidades de comportamento, qualidades expressivas e imaginativas, bem como o envolvimento pessoal na tarefa a realizar. Os "colaboradores", ou, como são classicamente chamados: os trabalhadores, são ali descritos pelas faculdades habitualmente próprias dos prestadores de serviços pessoais, dos "fornecedores de um trabalho imaterial impossível de quantificar, estocar, homologar, formalizar e até mesmo de objetivar" (p. 17).

Segundo Gorz, a informatização da indústria tende a transformar o trabalho em gestão de um fluxo contínuo de informações. "O operador deve 'se dar' ou 'se entregar' de maneira contínua a essa gestão de fluxo; ele tem de se produzir como sujeito para assumi-lo" (p.17). Neste sentido, a comunicação e cooperação entre os operadores é parte integrante da natureza do trabalho. "O desempenho repousa sobre sua implicação subjetiva, chamada também de 'motivação' no jargão administrativo, gerencial. O modo de realizar as tarefas, não podendo ser formalizado, não pode tampouco ser prescrito. O que é prescrito é a subjetividade, ou seja, precisamente isso que somente o operador pode produzir ao 'se dar' à sua tarefa" (p. 17). São esperadas qualidades dos trabalhadores tais como discernimento, capacidade de enfrentar o imprevisto, de identificar e resolver problemas.

Dentro destes parâmetros, a falta de mensurabilidade de execução de tarefas leva as empresas a recorrerem à chamada "gestão por objetivos". Os assalariados possuem metas e precisam se desdobrar para atingi-las. Estabelece-se, dentro da empresa, uma relação de "prestação de serviços", onde a empresa passa a ser o 
cliente do trabalhador, e este precisa "empresariar-se", vender seus serviços à empresa.

Essa nova modalidade de gestão empresarial implica em falas como a do diretor de recursos humanos da Daimler-Chrysler em 2001, uma consideração notada pela ausência total de toda e qualquer referência ao trabalho material. Na perspectiva pós-moderna, o fornecimento de serviços, o trabalho imaterial (Gorz, 2005), torna-se a forma hegemônica do trabalho, empurrando o trabalho material supostamente para a periferia do processo de produção. Ainda que permaneça indispensável, o trabalho material torna-se um "momento subalterno". "O coração, o centro da criação de valor, é o trabalho imaterial" (p. 19).

Este espaço discursivo pós-moderno é justamente o que percebemos embasar as práticas de qualidade de vida no trabalho. Enquanto pesquisador, partindo inicialmente da consideração de trabalho como trabalho material, pude ter acesso a uma série de práticas que não lhe diziam respeito. A maior parte do discurso sobre a Qualidade de Vida diz respeito ao trabalho, porém em sua modalidade imaterial, ou seja, remete-se ao estilo de vida do trabalhador, aos modos pessoais de resolução de conflitos no ambiente de trabalho (e mesmo fora dele), ao clima organizacional etc.

O trabalho imaterial não repousa sobre os conhecimentos dos trabalhadores, mas nas capacidades expressivas e cooperativas que não se pode ensinar; na utilização viva dos saberes e daquilo que o sujeito traz da cultura e do cotidiano. Para Gorz, esta é a grande diferença dos trabalhadores de manufaturas ou de indústrias taylorizadas e aqueles do pós-fordismo.

Os trabalhadores de manufaturas ou de indústrias taylorizadas precisam ser despojados de seus saberes, das habilidades e dos hábitos desenvolvidos pela cultura do cotidiano, para somente depois poderem ser "apropriados" pela máquina e sua divisão parcelada do trabalho. "Era necessário conseguir que o trabalhador executasse, com a regularidade de um autômato, e sem questionar, o comando que a maquinaria industrial Ihe transmitia, impondo-Ihe a velocidade e a cadência dos atos a executar" (p.19).

Os trabalhadores pós-fordistas, ao contrário, devem assegurar que toda sua bagagem cultural esteja à mercê do processo produtivo. Tudo que possa ser utilizado pela empresa deve ser mobilizado, principalmente as capacidades (competências) 
adquiridas em jogos, esportes de equipe, disputas, atividades musicais, teatrais etc. É na vida fora da trabalho onde as tão caras qualidades ao trabalho dito imaterial são desenvolvidas, como a capacidade de improvisação e cooperação. Moulier-Boutang (2000, apud Gorz, 2005), chama este processo de subsunção ao capital de "exploração de segundo grau", onde o trabalhador não mais se apresenta apenas como o possuidor de sua força de trabalho hetero-produzida (ou seja, de capacidades predeterminadas inculcadas pelo empregador), mas como um produto que continua, ele mesmo, a se produzir.

Combes \& Aspe (1998, apud Gorz 2005) afirmam: "Não são os indivíduos que interiorizam a 'cultura da empresa': mais que isso, é a empresa que vai de agora em diante buscar no 'exterior', ou seja, no nível da vida cotidiana de cada um, as competências e as capacidades de que ela necessita".

Pesquisar o que se chama de "qualidade de vida" no trabalho fez surgir diferentes enfoques que, se num primeiro momento pareciam não possuir nada em comum, com o decorrer da pesquisa evidenciaram tratar de diferentes modos de organização do trabalho coexistindo num mesmo tempo. Por exemplo, as "salas de descompressão" para operadores de telemarketing trata-se de uma ação organizacional focada em aliviar os sintomas produzidos em uma "linha de produção moderna", enquanto um workshop de qualidade de vida para executivos, baseado em gincanas e desafios grupais, está claramente direcionado para ajudar estes "operadores do trabalho imaterial" a se movimentarem de forma (supostamente) mais saudável nesta dimensão do chamado pós-fordismo.

No mundo atual do trabalho, onde convivem modos diferentes de racionalização do trabalho, oriundos de momentos históricos diferentes, alguns discursos afirmam-se hegemônicos. O tema desta pesquisa, a Qualidade de Vida no Trabalho, é um discurso desta grandeza e, tal como o "trabalhador pós-fordista", para sobreviver, foi se adaptando aos espaços e prometendo aquilo que estava ao seu alcance (e também aquilo que parecia estar ao alcance). 
Capítulo 5: Sobre o termo "Qualidade de Vida no Trabalho": Em busca de uma arqueologia 
A análise de artigos e livros sobre o tema da QVT indica, como talvez a única posição de consenso sobre o assunto, justamente a imprecisão do termo Qualidade de Vida no Trabalho (Fernandes e Gutierrez, 1988; Fernandes, 1996; Rodrigues, 1998; Detoni, 2001; Ayres, Silva e Souto-Maior, 2004; Tolfo e Piccinini, 1998; Mônaco e Guimarães, 2000; Heloani e Capitão, 2003).

Afirmar a imprecisão do termo indica que há diversidade de definições, porém esta diversidade, como foi possível constatar no decorrer desta análise documental, não se dá de forma amigável entre os autores. Há, portanto, uma disputa semântica envolvida, na qual diferentes autores procuram fazer prevalecer sua definição de forma hegemônica. Porém, para além desta disputa, ocorre simultaneamente uma disputa de poder (Foucault, 1997) que, por sua vez, interage na dinâmica do mercado de bens simbólicos (Bourdieu, 2005) ${ }^{10}$.

Segundo Foucault:

"Seria talvez preciso também renunciar a toda uma tradição que deixa imaginar que só pode haver saber onde as relações de poder estão suspensas e que o saber só pode desenvolver-se fora de suas injunções, suas exigências e seus interesses. (...) Temos antes que admitir que o poder produz saber (e não simplesmente favorecendo-o porque o serve ou aplicando-o porque é útil); que poder e saber estão diretamente implicados" (Foucault, 1979, p. 27)

\footnotetext{
10 “Todo ato de produção cultural implica na afirmação de sua pretensão à legitimidade cultural. Quando os diferentes produtores se defrontam, a competição se desenvolve em nome de sua pretensão à ortodoxia, ou então, para falar nos termos de Weber, ao monopólio da manipulação legítima de uma classe determinada de bens simbólicos" (Bourdieu, 2005, p.108). Por "produtores", Bourdieu engloba escritores, artistas e os eruditos.
} 
Devido à variedade de definições encontradas, optamos por apresentar alguns autores levando-se em consideração sua presença em artigos que remetem ao termo QVT. Dentre as publicações nacionais, autores que buscam definir o termo Qualidade de Vida no Trabalho remetem preferencialmente a Fernandes e Gutierrez (1988). Este artigo, Qualidade de Vida no Trabalho (QVT) - uma experiência brasileira, por sua vez, cita outros doze artigos, todos de origem estrangeira ${ }^{11}$, o que indica ser um dos primeiros artigos sobre o tema escrito no Brasil e fundado na discussão que ocorria em outros países.

Foucault (1972), em seu Arqueologia do Saber, articula os pressupostos da análise de discurso ao conceito de raridade, onde busca estar atento ao modo como determinados textos remetem uns aos outros, organizam-se em torno de uma mesma figura, convergem com instituições e práticas e podem se repetir em diferentes épocas, sob diferentes enunciados.

Este capítulo, portanto, após a análise de artigos e livros sobre o termo Qualidade de Vida no Trabalho, viu-se remetido a tantas descontinuidades que, para ser elaborado, utilizou-se de "inspiração" arqueológica.

\section{1) Publicações pioneiras no Brasil sobre o tema QVT}

Nacionalmente, o trabalho de Fernandes e Gutierrez (1988) pode ser considerado pioneiro dentro do tema $\mathrm{QVT}^{12}$, visto ser um dos mais antigos disponíveis, inclusive utilizando-se de citações estrangeiras devido à falta de material nacional, e, principalmente, devido à presença deste nos artigos e trabalhos que viriam a ser produzidos mais tarde.

Se as conceituações de QVT são diversas, diversas também são as tentativas de análise de origem do termo, por isso optamos por uma análise da evolução do termo nos artigos e livros mais citados na literatura nacional. Não só este artigo é citado pelos vindouros, como também, ao situar Walton (1973) como um clássico, parece ter iniciado uma grande presença do método deste autor norte-americano nas pesquisas

\footnotetext{
${ }^{11}$ Apenas o artigo de Westley (1980) possuía versão traduzida para a língua portuguesa.

12 Pioneiro quando considerado "específico" sobre o tema, visto que outros textos produzidos no Brasil, anteriores a este, já remetiam à questão da QVT, porém centralizando no sofrimento psíquico dos trabalhadores, como, por exemplo, Spink (1982a).
} 
nacionais, que passam, em grande número, a adotar este autor e as categorias por ele propostas como método de investigação para o cenário nacional (Rodrigues, 1998; Mônaco e Guimarães, 2000; Xavier e Quilici, 2006; Tolfo e Piccinini, 1998; Detoni, 2001). Em Detoni (2001), revisão bibliográfica realizada pelo autor também indicou o modelo de Walton (1973) como presente intensivamente no cenário nacional.

Segundo Fernandes e Gutierrez (1988), em países como Canadá, EUA e especialmente a França e a Suécia, a preocupação com a qualidade de vida do trabalhador vinha se intensificando, principalmente pelo "amadurecimento da sociedade" (p.30). Os teóricos da ciência comportamental preconizavam investimentos em

\footnotetext{
"um sistema integrado de compensação, elevação da segurança e condições de trabalho, maior participação por parte do empregado, liberação do potencial criativo, poder de decisão a nível do próprio cago, retroinformação sobre o desempenho, perspectivas de crescimento e outras tantas coisas que não geram custos adicionais, mas se refletem de maneira decisiva na qualidade de vida do trabalhador." (p.30)
}

Preocupados com uma sólida estruturação deste campo de atuação no Brasil, os autores afirmam a necessidade de se conceituar e compreender claramente no que consiste a QVT para que esta "tecnologia" não se transforme num modismo entre tantos outros que afligiram a literatura gerencial e que "têm certamente diminuído a credibilidade dos profissionais de $\mathrm{RH}^{\prime}$ (p.30). Apesar deste intuito, afirmam: "É preciso dizer, quanto à expressão 'qualidade de vida no trabalho', considerando-se exaustiva revisão bibliográfica sobre o tema, que não podemos atribuir-lhe uma definição consensual” (p.30).

Este artigo, que pode ser considerado pioneiro no Brasil, tanto pela data de publicação quanto pela quantidade de artigos que a ele se referem, busca em Walton (1973), autor americano, uma possível conceituação e, a partir desta data, este autor passa a ser citado em praticamente todos os artigos relativos à QVT em território nacional.

Segundo Walton (1973), “o conceito global [de QVT], além de atos legislativos que protegem o trabalhador, envolve o atendimento de necessidades e aspirações 
humanas, calcado na idéia de humanização do trabalho e responsabilidade social da empresa" (p.31).

Fernandes e Gutierrez também buscam uma definição no autor canadense Bergeron, onde a QVT

\begin{abstract}
“consiste na aplicação concreta de uma filosofia humanista pela introdução de métodos participativos, visando modificar um ou vários aspectos do meio ambiente de trabalho, a fim de criar uma nova situação, mais favorável à satisfação dos empregados da empresa" (Bergeron, 1982, apud Fernandes e Gutierrez, 1988, p.31).
\end{abstract}

Esses autores, ainda, expõem mais duas conceituações oriundas de publicações norte americanas. Ginzberg et aii (1979) afirma que a expressão “Qualidade de Vida no Trabalho" pode ser usada para reunir todas as experiências de humanização do trabalho sob dois aspectos diferentes, cada um, por sua vez, compreendendo muitas facetas. Em primeiro lugar, a reestruturação do emprego ou a reformulação dos postos individuais de trabalho; em segundo, a estruturação de trabalho semi-autogerenciados ou semi-autônomos, onde a reformulação dos cargos do grupo de trabalho implica em dar às pessoas um certo grau de participação (informação, consulta, co-decisão). (Ginzberg et aii, 1979, apud Fernandes e Gutierrez, 1988, p.31)

Neste artigo brasileiro ainda encontramos uma citação de origem americana que serve de referência para quase todos artigos pesquisados sobre o tema da QVT, publicados posteriormente ao artigo em questão. Trata-se de Nadler e Lawer (1983). Estes afirmam: "qualidade de vida no trabalho é vista como uma maneira de pensar a respeito das pessoas, trabalho e organização" (Nadler e Lawer, 1983, apud Fernandes e Gutierrez, 1988, p.31).

Após a revisão bibliográfica realizada pelos autores, este artigo nacional busca apresentar um aparato conceitual que forneça fatores e critérios que sustentem a formulação de modelos de avaliação e implantação de projetos de QVT. Segundo eles: “Em artigo que pode ser considerado clássico, por ter fornecido um modelo de análise de experimentos importantes sobre a qualidade de vida no trabalho, Walton ${ }^{13}$ (1973)

\footnotetext{
${ }^{13}$ Em nossa revisão bibliográfica, este foi o artigo nacional mais antigo a citar Walton (1973).
} 
propõe oito categorias conceituais como critérios de QVT (...)" (Fernandes e Gutierrez, 1988, p.31).

\section{2) Sobre a origem do termo Qualidade de Vida no Trabalho}

Não só foi possível encontrar diversas concepções de QVT, mas também divergem os autores com relação à origem do termo.

Nadler e Lawer apud Fernandes (1996), França (1997), Rodrigues (1999) e Vasconcelos (2001), oferecem uma interessante e ampla abordagem do termo QVT, conforme Quadro 1.

QUADRO 1 - EVOLUÇÃO DO CONCEITO DE QVT SEGUNDO NADLER E LAWER

\begin{tabular}{|l|l|}
\hline CONCEPÇÕES EVOLUTIVAS DA QVT & CARACTERÍSTICAS OU VISÃo \\
\hline 1. QVT como uma variável (1959 a 1972) & $\begin{array}{l}\text { Reação do indivíduo ao trabalho. } \\
\text { Investigava-se como melhorar a } \\
\text { qualidade de vida no trabalho para o } \\
\text { indivíduo. }\end{array}$ \\
\hline 2. QVT como uma abordagem (1969 a 1974) & $\begin{array}{l}\text { O foco era o indivíduo antes do } \\
\text { resultado organizacional; mas, ao } \\
\text { mesmo tempo, buscava-se trazer } \\
\text { melhorias tanto ao empregado como à } \\
\text { direção. }\end{array}$ \\
\hline 3. QVT como um método (1972 a 1975) & $\begin{array}{l}\text { Um conjunto de abordagens, métodos } \\
\text { ou técnicas para melhorar o ambiente } \\
\text { de trabalho e tornar o trabalho mais } \\
\text { produtivo e mais satisfatório. QVT era } \\
\text { vista como sinônimo de grupos } \\
\text { autônomos de trabalho, enriquecimento } \\
\text { de cargo ou desenho de novas plantas } \\
\text { com integração social e técnica. }\end{array}$ \\
\hline $\begin{array}{l}\text { Declaração ideológica sobre a natureza } \\
\text { (1975 a 1980) }\end{array}$ \\
\hline
\end{tabular}




\begin{tabular}{|l|l|}
\hline & $\begin{array}{l}\text { do trabalho e as relações dos } \\
\text { trabalhadores com a organização. Os } \\
\text { termos “administração participativa" e } \\
\text { “democracia industrial” eram } \\
\text { freqüentemente ditos como ideais do } \\
\text { movimento de QVT. }\end{array}$ \\
\hline 5. QVT como tudo (1979 a 1982) & $\begin{array}{l}\text { Como panacéia contra a competição } \\
\text { estrangeira, problemas de qualidade, } \\
\text { baixas taxas de produtividade, } \\
\text { problemas de queixas e outros } \\
\text { problemas organizacionais. }\end{array}$ \\
\hline 6. QVT como nada (futuro) & $\begin{array}{l}\text { No caso de alguns projetos de QVT } \\
\text { fracassarem no futuro, não passará de } \\
\text { um "modismo" passageiro. }\end{array}$ \\
\hline
\end{tabular}

Fonte: Nadler e Lawer apud Fernandes (1996, p. 42).

Silva (2001) apresenta o quadro de Nadler e Lawer modificado no campo 6, "QVT como nada (futuro)". Segundo a autora,

"Arrisca-se aqui alterar o quadro original que expõe a evolução e o conceito de Qualidade de Vida do Trabalhador, por considerar-se que o último item apresentado (o qual apontava, no futuro, "QVT como nada", sendo associado a um modismo passageiro), já não se aplica dentro do contexto existente em que se discute a responsabilidade social do estado, empresas, trabalhadores e sindicatos". (Silva, 2001, p. 25).

A alteração pela autora propõe:

\begin{tabular}{|c|c|}
\hline $\begin{array}{c}\text { 6. QVT como responsabilidade do Estado, } \\
\text { da Empresa, do Trabalhador e do Sindicato } \\
\text { (hoje e no futuro) }\end{array}$ & $\begin{array}{r}\text { É responsabilidade dos atores sociais - } \\
\text { Estado, Empresa, Trabalhadores e }\end{array}$ \\
$\begin{aligned} \text { conjuntacato - através da preocupação } \\
\text { e a sociedade em geral, dentro de um }\end{aligned}$ \\
\hline
\end{tabular}




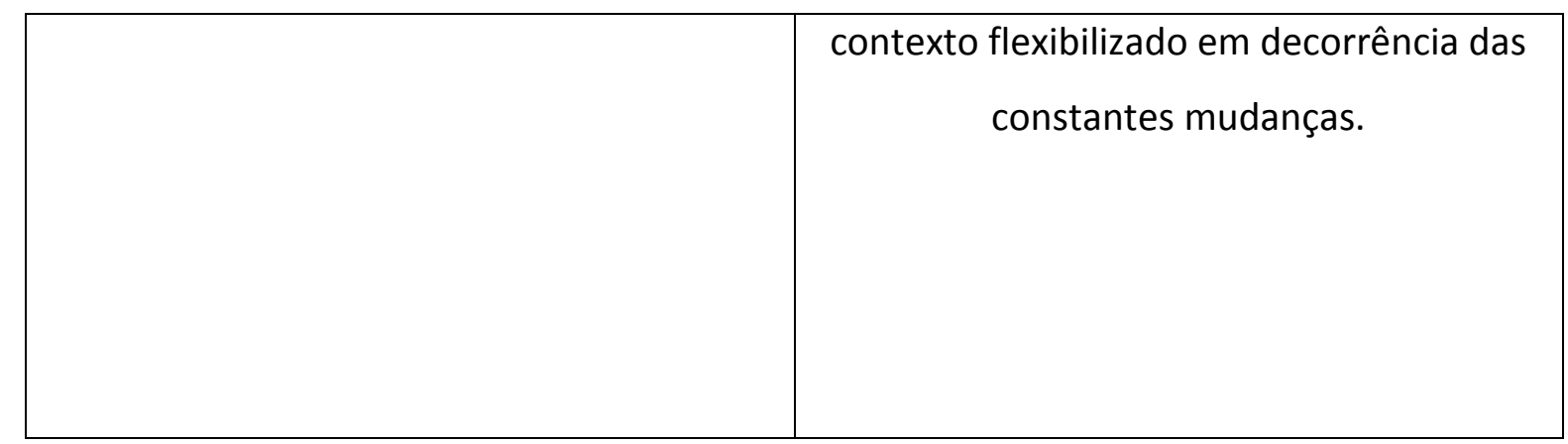

Silva (2001, p.24)

Para alguns autores, o tema da Qualidade de Vida no Trabalho possui origens remotas. Para Rodrigues (1999) o estudo da Qualidade de Vida no Trabalho sempre foi objeto de preocupação da raça humana, buscando facilitar ou trazer satisfação e bemestar ao trabalhador na execução de suas tarefas. Comenta que os ensinamentos de Euclides (300 a.C.) de Alexandria sobre os princípios da geometria serviram de inspiração para a melhoria do método de trabalho dos agricultores à margem do Nilo, assim como a Lei das Alavancas, de Arquimedes, formulada em 287 a.C., veio a diminuir o esforço de muitos trabalhadores.

Segundo Vasconcelos (2001) e França, Bosquetti e Veloso (2005), muitos pesquisadores contribuíram para o estudo sobre a motivação, satisfação e insatisfação do indivíduo no trabalho. Herzberg, McGregor e Maslow seriam considerados como um segmento dos movimentos de qualidade de vida no trabalho à medida que estudavam fatores organizacionais que funcionassem como incentivadores ou coibidores de motivação do funcionário.

Segundo estes autores,

"determinar a origem da preocupação com a saúde no trabalho pode significar estudar a origem da transformação da natureza pelo homem. Ou seja, a partir do momento em que o ser humano se utiliza de ferramentas e cria métodos para aperfeiçoar sua forma de subsistência, procurando de alguma forma reduzir seu esforço e diminuir seu sofrimento, pode-se dizer que há embutido o conceito de saúde atrelado ao trabalho" (França, Bosquetti e Veloso, 2005, p.2) 


\title{
5.3) Origem do termo QVT e a Escola Sociotécnica
}

França, Bosquetti e Veloso (2005) afirmam que, ao longo da história, é possível perceber diversas referências cujo foco é entender a relação do indivíduo com o seu trabalho. Destacam que, apesar de contribuírem para que o trabalho ganhe em qualidade de vida, o movimento de Qualidade de Vida no Trabalho possui origens "formalmente delimitadas na história do pensamento administrativo." Afirmam:

\begin{abstract}
"O movimento conhecido como QVT tem suas origens formais vinculadas ao desenvolvimento da abordagem sócio-técnica. O movimento conhecido como Relações Humanas, desenvolvida principalmente pelos estudos de Elton Mayo na Western Electric e de Eric Trist no Tavistock Institute of Human Relations de Londres, foi um ponto de partida para os estudos de QVT" (França, Bosquetti e Veloso, 2005, p.3)
\end{abstract}

Segundo Vieira (1996), Eric Trist, Ken Bamforth e outros, integrantes do Tavistock Institute em 1950, estudaram variáveis que futuramente serviriam para desenvolver o conceito de QVT. Citam Moraes e colaboradores (1996) como autores que apontam o trabalho de Trist como um modelo que engloba indivíduo, trabalho e organização visando a estruturação do trabalho assim como a satisfação dos funcionários. Comentam que durante as décadas de 50 e 60, principalmente nos Estados Unidos, o movimento de pesquisa em QVT teve uma rápida ascensão no meio acadêmico, período que coincide com o auge do fordismo e, concomitantemente, movimentos de reivindicação coletiva, com a expansão e consolidação do movimento sindical (Heloani, 1994).

Segundo Heloani (2003), Eric Trist afirma que a origem do termo QVT concerne a uma conferência internacional sediada em Arden House, em 1972, cujo tema principal versava sobre os "Sistemas Sociotécnicos".

França, Bosquetti e Veloso (2005) ressaltam que o termo ${ }^{14}$ Qualidade de Vida no Trabalho teria surgido de forma precisa em 1970, nos Estados Unidos, por Louis

\footnotetext{
${ }^{14}$ Os autores citados escrevem "conceito", porém preferimos nos referir à mesma definição de QVT como "termo" ou "noção", visto que a amplitude de definições encontradas nos diversos autores não indica ser adequado o uso da palavra "conceito", o que poderia passar uma impressão de "unidade" entre os autores.
} 
Davis. Algum tempo depois da definição do termo, esse pesquisador criou o Center for Quality of Working Life, na Califórnia, Estados Unidos, sendo que este pesquisador mantinha contato com os pesquisadores do Tavistock Institute e teria sido influenciado pelas pesquisas realizadas neste instituto. Durante a década de 70 , prolifera-se nos Estados Unidos centros de estudos sobre o tema, aliando, não ingenuamente, temas de QVT e produtividade. Segundo os autores citados, juntamente com centros de pesquisa em QVT é criado o National Comission on Productivity, nos EUA.

A crise do petróleo, porém, faz com que os investimentos em estudos sobre QVT fossem reduzidos, tanto pelo governo quanto pelas empresas, que passaram a focar na sobrevivência, deixando os interesses dos funcionários em segundo plano (Vieira, 1996). Estes autores afirmam que os estudos acerca da QVT foram retomados em 1980 por pesquisadores focados no tema, sendo chamados de "pertencentes formalmente à área de QVT", como Hackman e Lawer (1971), Walton (1973), Hackman e Oldhan (1975), Lippit (1978) e Westley (1979).

Segundo Spink (2003):

\begin{abstract}
"A teoria sociotécnica foi associada também com uma série de observações sobre a democracia no local de trabalho, entre elas a de que quando as pessoas têm a liberdade de se organizarem em torno das tarefas produtivas, elas tendem a criar modelos de organização flexível, nos quais as tarefas são compartilhadas e se desenvolvem habilidades múltiplas (os chamados agrupamentos semi-autônomos). Esse tipo de organização tem uma capacidade adaptativa em relação às flutuações do processo produtivo e propicia melhorias na qualidade de vida dos trabalhadores. Quando, ao contrário, a parte técnica é projetada de maneira independente (obedecendo a lógica da máquina), o resultado é uma série de restrições às possibilidades de organização social." (p.117)
\end{abstract}

Dentro da abordagem Sociotécnica podemos perceber a ligação entre a qualidade de vida dos trabalhadores e o poder destes em negociar modificações dentro dos processos de organização do trabalho. Dentre as abordagens que se debruçam sobre o tema da QVT, a Sociotécnica foi a única a ter seu nome vinculado à idéia de Democracia Industrial. 
Biazzi Jr. (1994) afirma que uma importante análise de Trist e seus colaboradores é o fato de que a elaboração de uma nova organização do trabalho caberia aos próprios trabalhadores, contrariando a Administração Científica. Neste sentido, a abordagem Sociotécnica difere completamente do "Enriquecimento do Trabalho $^{15 "}$ proposto por Herzberg (1959), no qual o trabalho é enriquecido para o operário, sem que ele participe do processo.

Esta abordagem chegou ao Brasil entre o final da década de 1970 e o início da década de 1980 (Spink, 2003), justamente quando a abertura democrática começava a tomar forma.

"Entretanto, para a grande maioria das lideranças empresariais, a democracia da sociedade e o mundo dentro dos portões das fábricas eram terrenos bastante diferentes. Com algumas poucas exceções, as agendas empresariais e sindicais se voltaram a outras questões." (Spink, 2003, p.118)

\section{4) QVT como decorrência do modelo de Qualidade Total}

Vimos que a origem do termo, por mais que seja imprecisa, possui referências datadas antes da década de 80. Porém, alguns autores afirmam que, na prática, a QVT aparece em decorrência do modelo de Qualidade Total. Segundo Barros (2003):

"O modelo de Qualidade Total, como instrumento de gerenciamento da produção, se substancia a partir da década de 80 , tendo sua origem na engenharia e visando, especialmente, a processos e controles produtivos e tecnológicos da fabricação do produto. Com a evolução do conceito de Qualidade Total para serviços, abriu-se nova discussão sobre a necessidade de incluir nele o conceito de Qualidade Pessoal e, conseqüentemente, o de Qualidade de Vida no Trabalho como parte dos Programas de Qualidade Total." (p. 15)

Segundo Zavattaro (1999) e Lacaz (2000), a noção de "qualidade de vida no trabalho" está fortemente sustentada nas inovações introduzidas nas empresas a partir da metade dos anos de 1980, quando os "programas de qualidade total"

${ }^{15} \mathrm{O}$ Enriquecimento do Trabalho consistiria numa constante substituição das tarefas mais simples por outras mais complexas, seguindo o crescimento individual do empregado de forma a oferecer-Ihe condições permanentes de desafio e satisfação profissional. 
disseminaram técnicas visando aprimorar a qualidade do processo e do produto/serviço por elas oferecidos.

O Programa de Qualidade Total visa melhorar o desempenho da empresa em três dimensões: $O$ produto em si, da concepção à venda; O ambiente interno; $A$ mobilização de todos os trabalhadores.

O ponto nevrálgico da QVT é justamente a mobilização de todos os trabalhadores da empresa. Planos de metas são elaborados e somente o envolvimento geral pode possibilitar o cumprimento dos mesmos. É justamente nessa dimensão que aparecem como preocupação dos gestores as questões acerca da motivação dos trabalhadores e o quanto estes estão satisfeitos com a empresa.

“Os Programas de Qualidade Total exigem pessoas que saibam fazer e principalmente que queiram fazer mais e melhor, por isso precisam contar com empregados satisfeitos" (Fernandes e Gutierrez, 1988, p.31).

O envolvimento dos funcionários da empresa para melhorar a produtividade é um norteador de alguns programas de QVT, conforme poderá ser visto no momento em que discutirmos alguns casos pesquisados acerca de programas de qualidade de vida no trabalho.

Em sua cartilha sobre a Qualidade Total, o SEBRAE afirma:

"É possível ter o máximo controle sobre os colaboradores, determinar normas rígidas, supervisionar, fiscalizar. Mas nada será tão eficaz quanto o espírito de colaboração e iniciativa daqueles que acreditam no trabalho." (SEBRAE, 2006)

Objetivando o aumento da qualidade e da produtividade nas empresas, através da eliminação de desperdícios com materiais, diminuição de refugos, do custo com a mão de obra, do custo final do produto e a busca de uma maior participação dos trabalhadores nas decisões operacionais (Rechziegel \& Vanalle, 1999), a gestão da Qualidade Total é buscada através de práticas como a do Gerenciamento do Ser Humano (Campos, 1992 apud Rechziegel \& Vanalle, 1999), definida por este autor 
como "um conjunto de princípios e práticas adotadas pela organização como forma de utilizar cada vez mais a mente do indivíduo e não somente a força braçal” (p. 33).

“QVT é uma evolução da Qualidade Total. É o último elo da cadeia. Não dá para falar em Qualidade Total se não se abranger a qualidade de vida das pessoas no trabalho. O esforço que tem que se desenvolver é de conscientização e preparação para uma postura de qualidade em todos os sentidos." (Albuquerque apud Limongi e Assis, 1995, p.29)

Neste sentido é que encontramos as apropriações ocidentais dos Círculos de Controle da Qualidade - CCQ propostos por Ishikawa (Rechziegel \& Vanalle, 1999), onde parte da responsabilidade pelo controle da qualidade foi transferida aos trabalhadores.

Se, por um lado, existem propostas para a QVT como humanização do ambiente de trabalho, com certeza, é em sua interface com programas de Qualidade Total que a QVT aparece claramente como uma estratégia voltada para a confecção do "produto perfeito", perfeito em sua concepção e em todas as etapas de sua elaboração. A idéia de "perfeição" é tratada como um atributo que vem agregar valor ao produto, tal como uma garantia de qualidade.

Podemos compreender, portanto, o porquê de se encontrar no mercado brasileiro a prática do Benchmarking ligado à área de QVT, que é a prática de se associar a marca da empresa à idéia de Qualidade de Vida no Trabalho, onde a empresa busca tornar-se referência para outras empresas em ações deste tema e, com isso, acaba por agregar valor ao nome da empresa.

Limongi-França \& Oliveira (2005), ao explicitarem o modelo de QVT da Empresa SERASA, por ocasião de um estudo de caso a respeito desta empresa, vencedora do Prêmio Nacional de Qualidade em duas oportunidades (1995 e 2000), afirmam:

“No aspecto Qualidade de Vida no Trabalho, são muitas as ferramentas e metodologias que visam criar e manter um ambiente de trabalho seguro, 
saudável e agradável. O processo de Qualidade de Vida é alinhado com o processo da Qualidade Total, e tem o objetivo de proporcionar aos funcionários o gerenciamento de sua saúde e estilo de vida, condições de bem estar pessoal e profissional, melhoria dos relacionamentos interpessoais, visando o equilíbrio entre mente e corpo, desenvolver de forma pró ativa a melhoria da satisfação com o trabalho, melhoria das práticas de saúde e redução de riscos." (Limongi e Assis, 1995, p.31)

\section{5) Autores de perspectiva crítica ao tema}

Ao situarmos alguns autores como "autores de perspectiva crítica ao tema", não estamos situando, necessariamente, os autores não-citados como "a-críticos", mas tão somente distinguimos aqui os autores de artigos que visam refletir sobre o papel da QVT enquanto manutenção do "status quo", tratando do tema sem o comprometimento de "fortalecer o movimento de QVT", como os autores citados anteriormente.

Segundo Heloani e Capitão (2003):

"o discurso manifesto encontrado nos folhetins que tratam das relações de trabalho parece demonstrar insistente preocupação com a melhoria da qualidade de vida dos que trabalham. Todavia, encontra-se uma política mundial de ajuste de custos que leva governos e empresas a minguarem as conquistas sociais alcançadas no último século pela classe trabalhadora" (2003, p. 105).

Em geral, na literatura de mercado direcionada aos profissionais de Recursos Humanos e administradores, o tema da QVT raramente é tratado em diálogo com reflexões acerca do contexto histórico-político nacional. As flexibilizações das relações de trabalho, principalmente seu reflexo no surgimento de um exército de mão de obra desempregada, influem diretamente nas possibilidades de negociação dos trabalhadores por melhores condições de trabalho, e, portanto, melhor qualidade de vida enquanto trabalhador, num contexto de precarização do trabalho.

"O que se constata é que a qualidade de vida do trabalhador, especialmente dos que vivem no terceiro mundo, vem-se degradando dia após dia" (Heloani e 
Capitão, 2003, p. 105). Segundo os autores, o encolhimento do mercado de trabalho tem restringido a luta dos trabalhadores à preocupações cada vez mais próximas às do início do século passado, como tão somente a sobrevivência.

Para estes autores, as relações de trabalho ficam ainda mais desumanas e aéticas frente à "competitividade desenfreada e os programas de qualidade total associados à produtividade e dissociados da QVT" (p. 106). A qualidade de vida seria portanto influenciada tanto pelas condições laborais quanto pela relação direta entre os trabalhadores, sendo que estes dois fatores se deterioram rapidamente em tempos de acirramento de competitividade.

Rechziegel \& Vanalle (1999) afirmam que o acirramento da competitividade e a luta por um produto de qualidade total levou à implementação das políticas de Qualidade Total, trazendo influências diretas sobre a qualidade de vida dos trabalhadores. Segundo estes autores:

\footnotetext{
"Algumas empresas conseguiram reduzir significativamente seus custos e aumentar sua produtividade, competitividade e lucratividade com a implantação da qualidade total, mas o mesmo não pode ser observado em relação aos funcionários, que não obtiveram aumentos reais em seus ganhos nessa mesma proporção, demonstrando que há contradições nessa 'parceria'." (p. 36).
}

O debate sobre a qualidade de vida no trabalho e os problemas de saúde que afetam os trabalhadores também tem sido desenvolvido em torno da questão sobre a gênese desses problemas e, por conseguinte, o locus de intervenção. Basicamente, duas têm sido as leituras: uma primeira que considera imprescindível estudar os contextos nos quais as pessoas trabalham, e a segunda que compreende a gênese desses problemas como adstritos à esfera intra-individual.

Sobre esse tema, Kompier \& Kristensen (2003) elaboram revisão bibliográfica sobre as intervenções em estresse organizacional, tomando em consideração as dimensões teóricas, metodológicas e práticas. Identificam que há uma preferência por intervenções no nível individual, voltadas para adaptar o trabalhador ao trabalho. Como dizem os autores, "o alvo principal é o trabalhador individual, em lugar do 
ambiente de trabalho ou da organização" (p. 41). Esse movimento pretere as intervenções que buscam repensar e modificar as condições e a organização do trabalho. Entretanto, como afirmara Gardell (1982), uma política voltada à melhoria da qualidade de vida e de saúde dos trabalhadores que busque adaptar o trabalhador aos esforços no trabalho transforma um problema social em problema individual. A seu ver, o caminho a ser adotado deve priorizar a leitura do contexto (condições e organização do trabalho) no qual as pessoas trabalham e estar orientado para a sua mudança. A mesma leitura é adotada por Spink (1982a, 1982b, 1991) e por Sato (1993 e 2002), que estudaram os limites e as possibilidades de replanejar o trabalho com vistas à melhoria das condições de saúde dos trabalhadores.

Porém, dividir o poder com os trabalhadores de forma a articular possibilidades concretas de replanejamento do trabalho não parece ter sido o rumo que as coisas tomaram. A participação dos trabalhadores foi transmutada na apropriação do saber do trabalhador pelo capital (Brito, 2005), o que, ao invés de dar poder ao funcionário ao possibilitar exercer seu conhecimento, configurou justamente o contrário: a empresa se apropria do conhecimento deste para se fortalecer, na mesma medida em que torna o funcionário como algo descartável, desvinculado deste "capital intelectual da empresa".

A vinda da Teoria Sociotécnica ao Brasil não impediu que esta também estivesse limitada às apropriações do empresariado nacional. Segundo Spink (2003):

\footnotetext{
"A abordagem sociotécnica chegou ao Brasil entre o final da década de 1970 e o início da década de 1980; quando o processo de abertura democrática ensaiava seus primeiros passos. Entretanto, para a grande maioria das lideranças empresariais, a democracia da sociedade e o mundo dentro dos portões das fábricas eram terrenos bastante diferentes. Com algumas poucas exceções, as agendas empresariais e sindicais se voltaram a outras questões. Para todos os efeitos, a teoria sociotécnica virou mais um capítulo na história da administração do trabalho, arquivado junto com outros modelos e teorias do mundo pré-globalizado. (...) Não ajudaram, numa época em que se valorizava cada vez mais a competência dos executivos e gerentes, as observações sobre a validade de métodos auto-gerenciados e sobre a capacidade dos trabalhadores de controlar processos produtivos complexos, sem supervisão."
} 
Apesar da abundante literatura sobre o tema da QVT, percebe-se uma perspectiva com enfoque cada vez mais abstrato, com poucas referências ao cotidiano do trabalhador. Heloani e Capitão (2003) alertam para a própria precarização do trabalho dos psicólogos que atuam em Departamentos de Recursos Humanos, afirmando que os processos de downsizing da atualidade vêm promovendo o esvaziamento destes Departamentos e transformando os psicólogos em consultores internos, cada vez mais distantes do envolvimento direto com os trabalhadores.

"Substituíram o chicote, o supervisor e os testes psicológicos pela ilusão da integração e da participação. É a tentativa da construção de uma nova subjetividade que encontra no projeto neoliberal a sementeira do individualismo e da barbárie" (Heloani e Capitão, 2003, p. 108)

É buscando a tentativa da construção de uma nova subjetividade que os programas de Qualidade de Vida do Trabalho atentam mais para o "estilo de vida" do que para as condições do trabalho propriamente ditas. Segundo Lacaz (2000):

“Ciborra e Lanzara (1985), assessores de uma central sindical italiana, criticam a noção de qualidade de vida no trabalho e propõem a terminologia qualidade do trabalho - mais adequada, na medida que procura incluir todas as características de uma certa atividade humana -, apontando que ela encerra uma atividade clínica, voltada à mudança de hábitos de vida e por isso atribuindo ao próprio trabalhador a responsabilidade de adaptar-se, de modo a optimizar sua qualidade de vida e de trabalho" (p.153).

Segundo este autor, as políticas empresariais de Promoção de Qualidade de Vida envolvem mecanismos de controle da percepção e subjetividade para "enquadrar trabalhadores mediante engrenagens que visam introjetar as normas e metas da empresa" (Lacaz, 2000, p. 153).

Concluindo, o que efetivamente define e concretiza a "qualidade (de vida no) do trabalho, é o controle - que engloba a autonomia e o poder que os trabalhadores têm sobre os processos de trabalho, aí incluídas questões de saúde, segurança e suas relações com a organização do trabalho - um dos mais importantes que configuram ou determinam a qualidade de vida (no trabalho) das pessoas" (Lacaz, 2000, p.154). 


\section{6) Algumas considerações sobre esta análise documental}

O tema Qualidade de Vida no Trabalho abrange uma grande diversidade de definições, propostas práticas e mesmo tentativas de se determinar a origem do termo. Se há alguma intersecção entre os autores, justamente é na comum afirmação de imprecisão do termo.

Além desta diversidade, algo importante que se faz presente nos textos consultados é a preocupação, presente nos autores que buscam fortalecer o termo, de situar a "Qualidade de Vida no Trabalho" como um tema nevrálgico para estudiosos em Gestão de Pessoas e de importância estratégica para Departamentos de Recursos Humanos.

Segundo Fernandes e Gutierrez (1988), "Uma sólida compreensão do que consiste QVT - 'qualidade de vida no trabalho' - impedirá que tal tecnologia se transforme em mais uma entre tantas modas gerenciais que têm certamente diminuído a credibilidade dos profissionais de $\mathrm{RH}^{\prime \prime}$ (p.30). Outros autores confirmam tal preocupação, o que nos leva a concluir que o tema, além de uma face importante para a área de Gestão de Pessoas, constitui uma "bandeira de luta" desta Escola da Administração que dialoga com a Psicologia Organizacional.

Os discursos vislumbrados pela análise documental indicaram a existência de algumas "matrizes". Segundo este prisma, a QVT poderia ser compreendida mediante as matrizes Humanista, Sociotécnica e Qualidade Total. Buscamos contemplar esta diversidade ao tratarmos deste tema.

Se, num primeiro momento, a maior parte dos livros e artigos consultados oriundos de autores ligados à Psicologia e à Administração focada em Gestão de Pessoas preconizava a promoção da Qualidade de Vida no Trabalho como um tema ligado à Teoria Sociotécnica e condizente com uma humanização do trabalho associada a maiores possibilidades de atuação do trabalhador em planejar e interferir nos processos de trabalho, podemos perceber que, com o passar do tempo, as publicações mais atuais parecem ter cindido as partes "sócio" e "técnica", esquecendo as sugestões de interferência na técnica e detendo-se tão somente nas temáticas 
"sociais", a saber: a "humanização do trabalho" - ambiente agradável, estilo de vida saudável e melhoria nas relações interpessoais - sem considerar as propostas de desenvolvimento de autonomia no interior da dimensão técnica do trabalho, presentes inclusive no tão citado trabalho de Walton (1973). As análises de conjuntura sócio-política destes trabalhos costumam ater-se às caracterizações das modificações do mundo do trabalho no contexto da pós-modernidade, por vezes tratando de assuntos como flexibilização e carreiras sem fronteiras, por exemplo.

A matriz que articula a promoção em Qualidade de Vida do Trabalhador e a filosofia da Qualidade Total foi encontrada quase exclusivamente em publicações oriundas das áreas de Administração Científica e Engenharia de Produção. Mais que almejar "humanização do trabalho", estas leituras tendem a buscar conciliar os altos índices de pressão por produtividade a níveis mais aceitáveis de satisfação com o trabalho. Estas publicações, ao discutirem análises de contexto sócio-político, costumam falar em termos mais familiares ao trabalhador comum - em contraposição aos da matriz humanista, trazendo elementos como precarização do trabalho, trabalhos temporários e desemprego.

A matriz Sociotécnica, por sua vez, acaba sendo resgatada somente nos momentos de "fundamentação teórica" acerca das origens da QVT em trabalhos acadêmicos, não sendo devidamente aproveitada naquilo que a Teoria Sóciotécnica traz de contribuição efetiva, como exposto anteriormente. Para Spink (2003):

\footnotetext{
"A abordagem sociotécnica nunca chegou a estar 'na moda' em termos administrativos; mesmo que sua influência entre pessoas preocupadas com a qualidade de vida no trabalho tenha sido razoável, a ponto de ser adotada no processo de projeção de fábricas na Suécia (Volvo) e no Canada (Shell). Em parte sua dificuldade foi intrínseca. Não sendo uma teoria normativa, as suas respostas eram sempre abertas."
}

Retomar esta escola sem falar das suas principais contribuições, portanto, é tratar questões como a democracia industrial tal como discursos interditos. Neste caso, mais que "negar" a Escola Sócio-Técnica, tal como exercendo o poder em sua forma repressiva, encontramos discursos que se apropriam "daquilo que este discurso pode dizer" nesta época, ou seja, daquilo que os novos sujeitos a se apoderarem dos 
enunciados acerca da Qualidade de Vida no Trabalho permitem que seja dito e apresentam como sendo a totalidade do discurso da Escola Sócio-técnica.

Os autores críticos ao tema atentam, entretanto, ao crescente individualismo no tratamento da QVT, depositando-se nos trabalhadores preocupações que concernem a toda uma complexidade de fatores. Neste sentido, caminha-se para uma crescente desresponsabilização das empresas quanto à saúde do trabalhador e às condições de trabalho, principalmente quando o tema é tratado cindido do contexto da precarização do trabalho. 
Capítulo 6: Reuniões de Profissionais de Recursos Humanos: O RH-Group 
Neste capítulo tratarei de dois encontros realizados por ocasião de um grupo de trabalhadores em recursos humanos. Há cerca de 15 anos, uma consultoria em Treinamento e Desenvolvimento empresarial promove um encontro mensal sobre algum tema relacionado à área de Recursos Humanos.

Durante estes encontros, realizados sempre na última quarta-feira de cada mês, reúnem-se trabalhadores de diversas empresas, consultores relacionados à área e ao tema específico daquela reunião e interessados em geral. Apesar de se descreverem como um "grupo informal de estudos e networking", o RH-GROUP possui formalidade suficiente para que as chefias das empresas liberem seus funcionários para participar das atividades, visto que elas ocorrem das $8 \mathrm{~h}$ às $12 \mathrm{~h}$. Há um valor a ser pago para participar, porém este se refere ao aluguel do espaço e destina-se também para a compra do café-da-manhã disponibilizado para os participantes durante a realização do networking.

As palestras, vivências ou dinâmicas de grupo agendadas têm início previsto às 8h30, e até este momento os participantes conversam, trocam cartões e contatos. Este momento volta a ocorrer após o término da atividade e esta dinâmica de networking consiste em boa parte do motivo deste grupo existir.

Este espaço consistiu, por duas oportunidades, em campo de pesquisa para o tema Qualidade de Vida no Trabalho. Primeiro, um treinamento acerca do Gerenciamento do Estresse e Qualidade de Vida no Trabalho, realizado em 2007, e um Workshop de Jogo Corporativo realizado por uma empresa que vende "Soluções em Qualidade de Vida" para Organizações, realizada em 2009.

Este capítulo objetiva apresentar algumas reflexões acerca da dimensão específica da venda de serviços ligados à qualidade de vida nas empresas. Estes 
serviços, conforme poderemos analisar, são apresentados enquanto discursos competentes (Chauí, 2006) e não como simples produtos. De fato, este espaço promove o contato dos trabalhadores em Recursos Humanos com consultorias especializadas em Qualidade de Vida, o que permite que se estabeleçam relações comerciais entre as partes. A empresa ou a consultoria que apresenta uma palestra ou vivência, por exemplo, costuma receber convites para elaborar projetos nas empresas de participantes do grupo presentes à reunião.

A inserção do pesquisador neste espaço se deu de forma a contemplar as possibilidades que o ambiente apresentava. Diferente do capítulo de análise documental, ou mesmo do capítulo onde apresentamos entrevistas com consultoras, este espaço, para ser "pesquisado", implicou em um pesquisador mais atuante do que apenas um observador. A dinâmica narrativa deste capítulo, portanto, inclui a apresentação de um pesquisador que está dialogando com as possibilidades do campo, resultando em uma alternância de momentos mais descritivos para possibilitar ao leitor visualizar o contexto onde o discurso aparecia e momentos onde a estrutura narrativa se aproxima da forma de um diário de campo. 


\section{1) Treinamento: Gerenciamento do Estresse e Qualidade de Vida no Trabalho}

A palestra sobre estresse durou aproximadamente 120 minutos e durante a primeira hora foi apresentado o mecanismo fisiológico do estresse no corpo humano, explanação que não cabe destrinchar longamente aqui. Ao final da apresentação fisiológica, apresentou-se o método da Respiração Ayur-védica, durante cerca de 1 hora, com uma metodologia mais parecida a de um workshop, onde os presentes eram incitados a experimentar entrar em modo de relaxamento e seguir a respiração ensinada. Após o término da apresentação da especialista, Dra. Cláudia, formada em Psicologia e Educação pela USP, permanecemos por cerca de mais uma hora em uma sessão de perguntas e um debate que tocou questões absolutamente fora da Fisiologia e pertinente ao mundo do trabalho, debate no qual nos permitiremos trabalhar com detalhes.

Durante a primeira hora de palestra, a apresentação sobre fisiologia mantevese na esfera estritamente técnica. Os cerca de 35 presentes permaneceram atentos e fazendo anotações.

Apesar de ser uma vivência orientada para profissionais de setores de Recursos Humanos, o "evento desencadeador do Estresse" ${ }^{16}$ era discursado de forma abstrata e genérica, ou seja, sem relações claras com o mundo do trabalho, cargos, funções, organizações e etc. Os exemplos utilizados eram genéricos: um susto pelo elevador ter parado de repente entre dois andares, um cachorro que late e um assalto, por exemplo, foram exemplos usados indiscriminadamente.

Ao se explicitar o mecanismo do estresse no corpo humano, este aparecia de forma bio-mecânica e, enquanto mecanismo fisiológico, atuava da mesma forma, independentemente do agente estressor (cachorro, assaltante, etc).

\footnotetext{
16 "Evento desencadeador do Estresse" é a denominação da situação ou fenômeno que a pessoa estressada vivenciou e que provocou o aparecimento dos sintomas característicos do estresse.
} 


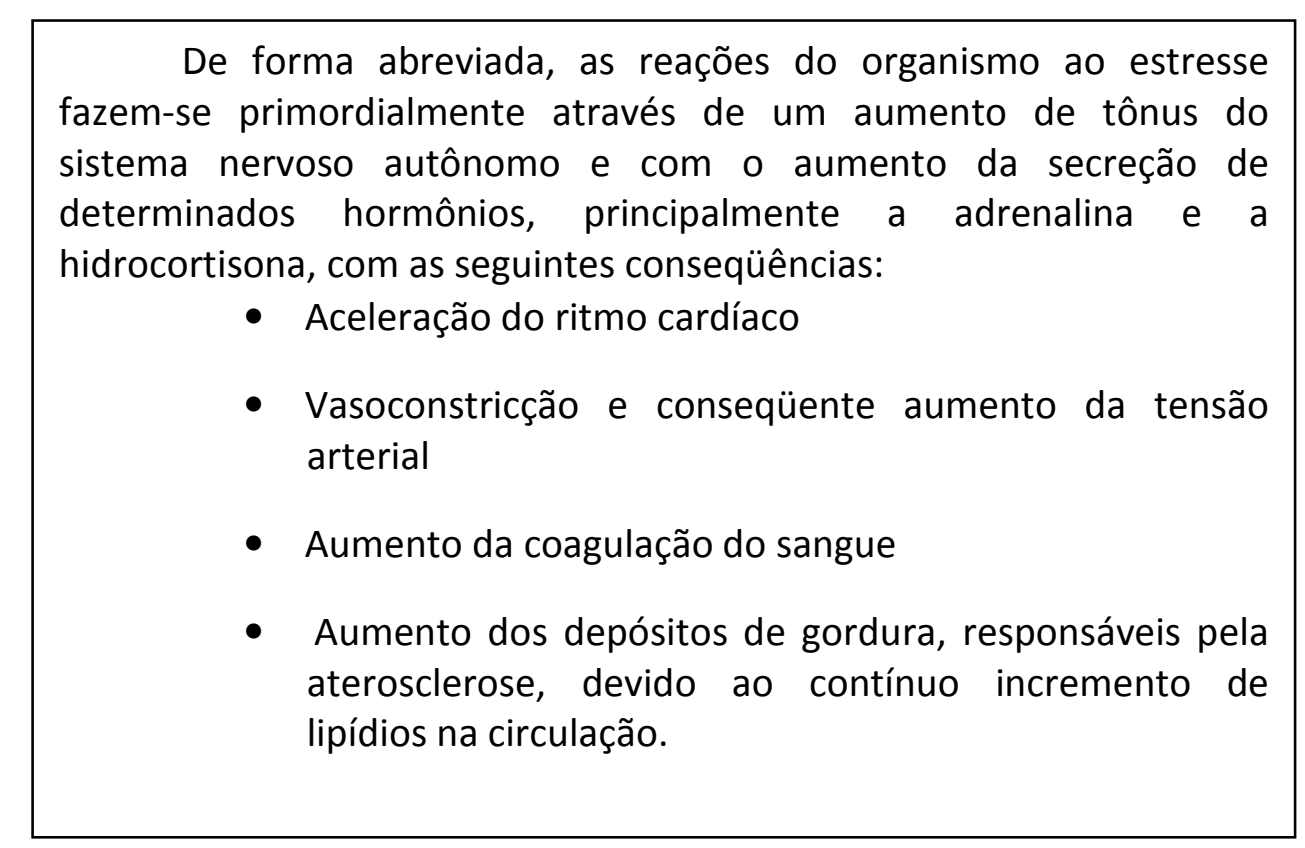

Esta apresentação inicial constituiu a base para o segundo momento da explanação da Dra. Cláudia: como gerenciar o estresse.

Utilizando-se do exemplo relativo a "voar de avião", a Dra. explicitou o quanto o mecanismo respiratório torna-se superficial e com contrações pulmonares curtas, onde percebe-se o tórax inflando e desinflando rapidamente, com a entrada e saída rápida de pouco ar.

A Dra. apresentou, então, um mecanismo oposto de respiração, que remete à respiração do bebê. Segundo a especialista, em momentos de estresse, pânico e medo, devemos lembrar a imagem de um bebê dormindo, cujo tórax quase não se mexe, mas a barriga infla vagarosamente até seu máximo e depois se segue uma transpiração total calma e ritmada.

Dra. Cláudia, após esta introdução inicial, pediu para que todas as pessoas presentes colocassem a mão sobre a própria barriga e imaginassem seu diafragma controlando sua respiração. Foi realizado um exercício de tentativa de diminuir o ritmo dos batimentos cardíacos mediante o controle consciente da respiração, "usando-se a barriga para respirar" e não o tórax.

Após cerca de 5 minutos, ela interrompeu o exercício e pediu para que todos dissessem como tinham sentido o experimento. Pela primeira vez, Dra. Cláudia utilizou um exemplo retirado do mundo do trabalho, mesmo sendo consultora sobre Estresse e Qualidade de Vida para Organizações. 
Segundo Dra. Cláudia:

\begin{abstract}
"Eu tive uma cliente que sofria muito com o chefe. Ela era secretária e acontecia de ele a humilhar, ela até chegou a chorar e estava a ponto de jogar um cinzeiro na cara do chefe. Após aprender a respiração Ayur-védica, ela veio me contar que a vida dela melhorou muito, porque agora, quando o chefe tinha seus momentos de raiva e ficava gritando, ela se concentrava em sua respiração e controlava seus batimentos cardíacos. Nem escutava mais o que ele falava, de tanta concentração!"
\end{abstract}

Todos os presentes, frente esta declaração de assujeitamento ao poder instituído - e autoritário, riram. A situação narrada, uma situação de humilhação ostensiva, passou a pairar junto a outras de caráter "genérico" enquanto gatilho de estresse, como um elevador parar entre dois andares.

É de se notar que a condição desta secretária seja descrita enquanto um organismo com o ritmo cardíaco extremamente acelerado, alta pressão sanguínea devido à vasoconstricção e sangue inundado por adrenalina tensionando músculos etc. Não se trata da descrição de uma situação de humilhação social. Trata-se tão apenas de um organismo que se desestruturou frente a um "gatilho" e que pode beneficiar-se das propriedades da respiração adequada ao gerenciamento do estresse.

Neste discurso, o trabalho enquanto categoria central (Antunes, 2007) não existe, o que existe é uma situação que ocorre "durante a jornada" de trabalho.

Na fala da especialista em Gerenciamento do Estresse e Qualidade de Vida, qual foi o gerenciamento desta situação de estresse (secretária a ponto de jogar o cinzeiro no rosto do patrão enquanto é humilhada)? Pela especialista, a situação foi controlada - e com sucesso - pela secretária ao passo que esta puxa para sua responsabilidade o fato de precisar "lidar com" a situação de forma a manter ao máximo sua integridade física. No caso, segundo o discurso da consultora, podemos concluir que faltava à secretária a habilidade de respirar de forma correta durante a humilhação. Após o curso, com esta habilidade adquirida, ela conseguiu permanecer no emprego e manter-se "menos estressada".

Neste caso, o uso da técnica de respiração para controlar efeitos do estresse acaba caindo na infeliz função de adaptar o corpo às condições inaceitáveis de trabalho, ao invés de buscar repensar estas condições. 
Segundo Kompier e Kristensen (2003), a redução do estresse é primordialmente uma "abordagem band-aid" (p. 41). Estes autores citam Kahn \& Byosiere: "Esta atividade está desproporcionalmente concentrada na redução de efeito ao invés da redução da presença de estressores no trabalho". (Kahn \& Byosiere apud Kompier e Kristensen, 2003, p. 41)

\begin{abstract}
“O Principal alvo é o indivíduo. (...) o alvo principal é o trabalhador individual, em lugar do ambiente de trabalho ou da organização. Uma abordagem orientada para o trabalhador, por exemplo, pela melhora das habilidades dos empregados em lidar com, resistir ou reduzir o estresse (a abordagem de vacinação contra estresse), é seguida mais freqüentemente do que uma abordagem orientada para o trabalho, por exemplo, pela mudança do estilo gerencial ou aumento do controle (pelos trabalhadores). A maioria dos programas objetiva a redução da avaliação cognitiva de estressores e seus efeitos subseqüentes. Tipicamente, essas intervenções são "prescritivas, orientadas para a pessoa: técnicas baseadas em relaxamento, como relaxamento muscular progressivo, biofeedback, meditação e treinamento em habilidades cognitivo-comportamentais" (Murphy, 1996)" (Kompier e Kristensen, 2003, p. 41)
\end{abstract}

Não pensamos que a respiração Ayur-védica (também chamada de Respiração Diafragmática) não traga, em alguma medida, bem estar a aqueles que a praticam. Apesar de ser cientificamente comprovado que o estresse desencadeia uma corrente de adrenalina no sangue, provocando vasoconstriç̧ão, aumento da pressão e aceleração dos batimentos cardíacos, e também apesar de a prática da concentração na respiração e seu controle treinado poder diminuir os efeitos do estresse no organismo, isto não implica que este tipo de intervenção, principalmente focado no corpo da vítima, seja constituinte de uma intervenção que busca melhorar a qualidade de vida no trabalho de um funcionário.

O que queremos dizer com esta descrição que se atém em caracteres oriundos da Fisiologia é que, apesar de um discurso ser montado em sua maior parte com informações científicas, isto não impede que uma pequena consideração moral (no caso, de "como é melhor" administrar estes recursos) o transforme por inteiro em um produto que em nada lembra a intenção de neutralidade da ciência. 
Este exemplo desencadeou diversas intervenções realizadas pelos presentes, onde situações análogas eram descritas, como se os participantes estivessem vislumbrando situações onde poderiam "aplicar" seu novo conhecimento.

Após uma breve pausa para um café, os presentes organizaram-se de modo a formar um círculo para que uma conversa em grupo pudesse ser realizada. A primeira pergunta foi realizada por uma funcionária de $\mathrm{RH}$ de uma empresa ${ }^{17}$. A participante levantou o braço e, ao the ser dada a palavra, abaixou a cabeça e afirmou: "Na minha empresa tenho 17 funcionários afastados por estresse, eu não sei mais o que fazer." Imediatamente, um burburinho de falas angustiadas começou entre os participantes, como se esta fala tivesse trazido à tona toda a tensão dos participantes: a grande maioria dos funcionários de RH presentes estava na mesma situação.

Dentre as falas concomitantes, outra pessoa presente afirmou que também tinha este problema e reclamou que os diretores de sua empresa a pressionavam para "resolver" os casos e diminuir os afastamentos. Outros participantes afirmaram estar na mesma situação e deu-se um momento no grupo onde críticas a gestores e diretores foram expostas.

A palestrante passou a conversar com alguns dos presentes, com falas de acolhimento. Dirigia-se a alguém que falava mais alto sobre as dificuldades de trabalhar onde ela era funcionária e comentava: "Sim, eu sei que é muito difícil, isso acontece em todas as empresas..." e também " $A$, sim... Compreendo... realmente você deve estar exausta". A conversa passou a girar em torno do fato de como os presentes deste encontro focado no estresse estavam verdadeiramente estressados.

Dentre as falas de acolhimento da coordenadora do grupo e as lamentações de diversos participantes, a primeira pessoa a levantar a questão dos afastamentos perguntou à especialista: "O que eu faço com estas pessoas?" Mantendo uma expressão facial que indicava acolhimento, a especialista calou-se.

As condições específicas do encontro possibilitaram uma alteração de minha postura para a de um pesquisador mais participante, como comentarei a seguir.

Frente ao silêncio da especialista e, principalmente, frente à angústia da participante, questionei sobre a condição dos tais 17 trabalhadores afastados para

\footnotetext{
${ }^{17}$ Os participantes dividiam-se em funcionários de RH e consultores, fossem os do próprio RH-GROUP, ou consultores "independentes", que estão lá realizando networking profissional visando fazerem-se conhecidos dentre profissionais de RH que possam vir a ser potenciais clientes.
} 
que, naquele espaço de debate, pudéssemos tentar fornecer-lhe mais do que um olhar acolhedor. Perguntei: "17 trabalhadores de quê, fazem o quê?"

Um silêncio ainda maior tomou o grupo. A participante pareceu ter ficado um pouco constrangida e respondeu: "Trabalhadores da minha empresa... Eles trabalham lá... Por quê?" Continuei: "Porque é importante, o quê eles fazem? Sem saber isso eu não consigo pensar em algo pra te falar que possa te ajudar ao que fazer com eles." Ela respondeu: "Bom, eles estão estressados".

Dentre o burburinho sobre minha pergunta, dois claramente disseram: "Mas por que você quer saber o que eles fazem?" Reafirmei a importância de saber o que um trabalhador afastado faz para poder opinar sobre alguma saída para o caso. Alguns poucos pareceram concordar. A funcionária de RH disse, então: “Minha empresa é uma indústria pequena de químicos". Fiquei em silêncio alguns instantes, esperando que ela comentasse algo mais, mas novamente caímos no silêncio. As pessoas presentes pareciam realmente satisfeitas com a explanação sobre o tipo de negócio onde a empresa daquela pessoa atuava.

Novamente, falei ao grupo sobre o fato de precisarmos levar em conta qual o trabalho exercido pelos sujeitos para que possamos pensar em questões relativas a estes trabalhadores. Retomei a pergunta sobre o quê efetivamente fazem estes trabalhadores e comentei sobre o quão difícil era tentar entender o problema dela quando não sabia qual a concretude do cotidiano daqueles funcionários. Um silêncio incômodo tomou conta do círculo formado pelas pessoas.

A funcionária em questão demonstrava-se mais aflita do que antes e o grupo em uma tensão maior ainda. A coordenadora da consultoria que organiza o RHGROUP, uma senhora com reconhecida experiência em Recursos Humanos, levantouse e, falando de forma didática, afirmou: "Eu estou entendendo o que ele quer dizer, eu também concordo com isso. Precisamos chegar até as pessoas, não lidar somente com uma mega organização gigante. No meu trabalho na consultoria levamos isso em consideração." Uma certa calma se estabeleceu enquanto esta senhora falava.

A consultora olhou para a pessoa que havia feito a pergunta inicial e, no ânimo de calmaria que tomava conta do grupo, perguntou sorridentemente: "Será que não seria bom para você realizar uma atividade na sua empresa com estes trabalhadores, inclusive com questões como a respiração ayur-védica?". 
Esta fala permitiu-me vislumbrar o grupo RH-GROUP em seu viés mais pragmático: um espaço onde, mediante palestras, workshops e vivências, consultores literalmente ofereciam seus serviços aos participantes que trabalhavam em departamentos de Recursos Humanos de empresas diversas.

Ao final desta "oferta de solução", frente ao silêncio reflexivo da participante, afirmei: "Talvez não seja bom para ela, porque talvez não seja bom para os trabalhadores estressados realizarem um trabalho de respiração profunda sendo que não sabemos o que eles realizam, e, por exemplo, podem estar expostos a gases tóxicos ou poeiras, e um trabalho desses sem levar em conta o que eles realizam pode atuar ao contrário, piorando a vida deles. Seria como colocar mineradores de carvão para respirarem profundamente".

Imediatamente ficou claro um clima de constrangimento coletivo, rapidamente dissolvido pela voz da coordenadora do RH-GROUP: "Claro, concordo com você novamente, e isso é levado em consideração sim, sempre levamos isso em consideração. Eu entendo o que você está querendo dizer sim."

No sentido de explicitar o quanto aquela situação não era exclusiva da empresa química citada, outros presentes comentaram que em suas empresas também havia pessoas afastadas por estresse, o que acabara "estressando-os" enquanto funcionários de Departamentos de Recursos Humanos. Comentaram sobre as pressões sobre o RH para que "as pessoas parassem de adoecer" (fala de um dos participantes).

O tempo previsto para o evento estava se esgotando e as coordenadoras do evento anunciaram que haviam conseguido convencer uma das consultoras, especialista em Danças Circulares, a realizar uma "vivência" breve com a participação dos presentes. Segundo esta consultora, a Dança Circular era parte das atividades de Motivação e Melhoria de Relacionamentos de Trabalho que ela realizava enquanto consultora em empresas. Pediu, então, que ficássemos de pé e formássemos dois círculos de pessoas, um dentro do outro, porém com o círculo menor contando com apenas duas pessoas a menos que o maior, de forma a deixar os círculos completamente próximos. O círculo menor se formou e as pessoas rapidamente deram as mãos para a formação do círculo maior.

A consultora, estando no círculo menor, começou a cantar uma música rítmica fácil de ser acompanhada pelos demais e passou a dar indicações de como todos 
deviam dançar juntamente, com o círculo se ovalando e se achatando conforme o canto e com os círculos girando em direções opostas em alguns momentos.

Após algum tempo nessa dinâmica de grupo, a reunião foi encerrada.

Podemos dividir as atividades deste dia em quatro momentos muito importantes para nossa análise: Uma parte ligada à descrição fisiológica do mecanismo do estresse, uma parte ligada à apresentação de uma espécie de estratégia para lidar com o estresse, a abertura para o debate e uma dinâmica de grupo também ligada à QVT.

A primeira hora da palestra, centrada na exposição fisiológica do problema, apesar de não aparecer novamente em nenhum momento posterior das atividades, possui uma enorme importância para a configuração total da apresentação. A explicitação proficiente pela palestrante do mecanismo fisiológico - apresentação inquestionável, pois travestida de ciência pura - promove um "empréstimo de autoridade" científico ao discurso que se seguirá. Cabe aqui deixar claro que a divisão entre "momento fisiológico" e "técnica da respiração ayur-védica" é uma divisão analítica realizada aqui, pois às pessoas que estavam presentes, estas perspectivas foram apresentas de forma uníssona.

Se a proposta da palestrante era apresentar o método ayur-védico, a introdução de caráter médico busca apresentar algo que possui origem na meditação religiosa como embebido de caráter científico. Utilizaremos aqui a noção de idelogia, no intuito de esquadrinhar o caminho pelo qual este discurso veio a ser verdade, neste espaço e neste momento.

A introdução, portanto, pede emprestado à ciência positiva estabelecida um status de neutralidade à segunda parte da exposição: o método de respirtação ayurvédico.

"uma ideologia não é necessariamente 'falsa': quanto a seu conteúdo positivo, ela pode ser 'verdadeira', muito precisa, pois o que realmente importa não é o conteúdo afirmado como tal, mas o modo como esse conteúdo se relaciona com a postura subjetiva envolvida em seu próprio processo de enunciação. Estamos dentro do espaço ideológico propriamente dito no momento em que esse conteúdo - 'verdadeiro' ou 'falso' (se verdadeiro, tanto melhor para o efeito ideológico) - é funcional com respeito a alguma relação de dominação social ('poder', 'exploração') de maneira 
intrinsecamente não transparente: para ser eficaz, a lógica de legitimação da relação de dominação tem que permanecer oculta. Em outras palavras, o ponto de partida da crítica da ideologia tem que ser o pleno reconhecimento do fato de que é muito fácil mentir sob o disfarce da verdade." (Zizek, 1996, p. 13 - itálicos do autor)

Apesar do mecanismo de estresse apresentado ser satisfatório enquanto "cientificamente verdadeiro", e que a respiração realizada da forma descrita provoca tal oxigenação e relaxamento muscular de forma $a$, in loco, atenuar sintomas do "mecanismo fisiológico estressado", toda a apresentação fica comprometida devido ao uso a que se propõem tais conhecimentos. Segundo Derrida (apud ZizeK, 1996) a própria moldura é parte do conteúdo enquadrado e, neste caso, a moldura que inviabiliza toda e qualquer possibilidade de "boa intenção científica" é o fato deste discurso ser direcionado a pessoas que, como a palestrante exemplificou, estão estressadas a ponto de jogar um cinzeiro no rosto do patrão por não suportarem mais humilhações e pressões.

Quando o exemplo citado é apresentado, ele aparece tal como uma amostra do sucesso da técnica. Após "qualificar-se" em respiração ayur-védica pelo curso da palestrante, a secretária passou a dispor de condições para sobreviver no ambiente de trabalho. Esta dimensão explicativa do fenômeno afirma que, dentre as possibilidades de intervenção, trabalhar simplesmente a nível individual foi acertado.

\footnotetext{
"A idéia de sujeito plenamente 'responsável' por seus atos, em termos morais e criminais, claramente atende à necessidade ideológica de esconder a complexa trama, sempre já operante, dos pressupostos histórico-discursivos, que não apenas dão o contexto do ato praticado pelo sujeito, mas também definem de antemão as coordenadas de seu sentido: o sistema só pode funcionar se a causa de sua disfunção puder ser situada na 'culpa' do sujeito responsável." (Zizek, 1996, p.11)
}

O terceiro momento da atividade - as perguntas e o debate entre os participantes - nos remete ao porque das duas primeiras partes. Nossa pergunta (de clara inspiração genealógica) aqui é: Se este discurso aparece tal qual verdade, a quem interessa que isso de fato o seja? 
Neste sentido, o terceiro momento, onde alguns participantes apresentaram questões de suas empresas e escutaram sugestões dos especialistas, demonstra que o discurso apresentado interessa aos seus enunciadores (os especialistas) que seja verdade, pois, desta forma, configura-se tal como um produto interessante a ser comprado pelos profissionais de $\mathrm{RH}$ presentes.

"O fundamental da análise (genealógica) é que saber e poder se implicam mutuamente: não há relação de poder sem constituição de um campo de saber, como também, reciprocamente, todo saber constitui novas relações de poder" (Machado, 1979 p. XXI).

A consultora em Estresse e QVT, quando questionada teoricamente acerca da importância de qual o trabalho do sujeito estressado, foi colocada em xeque também em sua dimensão de poder enquanto consultora "capaz de" atuar junto às empresas para trabalhar a questão do Estresse e QVT. Isso explica o fato de outra consultora intervir e dizer "Eu estou entendendo o que ele quer dizer, eu também concordo com isso." Esta frase busca reterritorializar (Deleuze, 2002) o campo discursivo de forma a retomar o espaço de discurso competente (Chauí, 2006), ou seja, mais que demonstrar a força de seus argumentos, buscava-se afirmar que "sabia-se" sobre o assunto, numa tentativa de se manter como sujeito nos enunciados da questão (Foucault, 1972).

Afirmando proficiência no assunto, a consultora diluiu o constrangimento daquele momento onde as falas deixavam claras as contradições entre os modos de se encarar o problema. Ao afirmar que concordava com a fala discordante e, além disso, dizer: "No meu trabalho na consultoria levamos isso em consideração", a consultora se aplica a dissolver a contradição entre as perspectivas dos participantes. Se ela "concorda com os dois lados" é porque, em alguma instância, as duas posições são conciliáveis.

\footnotetext{
"Universalizando o particular pelo apagamento das diferenças e contradições, a ideologia ganha coerência e força porque é um discurso lacunar que não pode ser preenchido. Em outras palavras, a coerência ideológica não é obtida malgrado as lacunas, mas, pelo contrário, graças a elas. Porque jamais poderá dizer tudo até o fim, a ideologia é aquele discurso no qual os termos ausentes garantem a suposta veracidade daquilo que está explicitamente afirmado". (Chaui, 2006, p.15-16)
} 
Neste discurso das consultoras, o importante não era "ganhar a argumentação", não era nem mesmo demonstrar que o produto delas era viável e aplicável a quaisquer trabalhadores. O discurso delas lutava para se mostrar competente. As críticas, ao invés de serem tidas como argumentos a serem rebatidos, eram prontamente apropriadas como algo "já por demais conhecido", pois este é o papel simbólico do especialista: saber do que se trata, e, mais que isso, tranqüilizar as pessoas de que tudo está sob controle, pois há um especialista que sabe o que está acontecendo.

"O que é o discurso competente enquanto discurso do conhecimento? Sabemos que é o discurso do especialista, proferido de um ponto determinado da hierarquia organizacional. Sabemos também que haverá tantos discursos competentes quantos lugares hierárquicos autorizados a falar e a transmitir ordens aos degraus inferiores e aos demais pontos da hierarquia que the forem paritários. Sabemos também que é um discurso que não se inspira em idéias e valores, mas na suposta realidade dos fatos e na suposta eficácia dos meios de ação. Enfim, também sabemos que se trata de um discurso instituído ou da ciência institucionalizada e não de um saber instituinte e inaugural e que, como conhecimento instituído, tem o papel de dissimular sob a capa da cientificidade a existência real da dominação" (Chaui, 2006, p.23)

As perguntas que eu fiz à pessoa responsável pelos trabalhadores afastados levantou uma questão que, ao ser colocada, demonstrou ser incômoda: afirmar a importância de se pensar concretamente nos "trabalhadores afastados" enquanto sujeitos e não enquanto objetos organizacionais. Pensar na função realizada, salário recebido, turnos, disciplina etc, era complexificar a situação de forma a suscitar ameaçadoramente (às especialistas de um saber abstrato) que existe um saber local àquela empresa que precisa ser levado em consideração para se compreender a condição daqueles trabalhadores.

Deixar transparecer que aquela funcionária de $\mathrm{RH}$, que trabalha na mesma empresa dos trabalhadores afastados, pudesse saber mais sobre eles do que as especialistas no assunto, foi recebido como uma provocação. As consultoras presentes, estudiosas do assunto, poderiam - provavelmente - ter contribuições a dar àquela funcionária, porém, para além disso, existia uma configuração da hierarquia de 
saber, naquele grupo, onde buscava-se demonstrar que "somente" elas poderiam ter algo a contribuir. Se aquela pessoa que trabalha no local "conflituoso" fosse portadora de um saber, as especialistas teriam seu saber/poder relativizado.

\begin{abstract}
"O discurso competente é o discurso instituído. É aquele no qual a linguagem sofre uma restrição que poderia ser assim resumida: não é qualquer um que pode dizer a qualquer outro qualquer coisa em qualquer lugar e em qualquer circunstância. O discurso competente confunde-se, pois, com a linguagem institucionalmente permitida ou autorizada, isto é, com um discurso no qual os interlocutores já foram previamente reconhecidos como tendo o direito de falar e ouvir, no qual os lugares e as circunstâncias já foram predeterminados para que seja permitido falar e ouvir e, enfim, no qual o próprio conteúdo e a forma já foram autorizados segundo os cânones da esfera de sua própria competência." (Chaui, 2006, p.19)
\end{abstract}

O último momento das atividades deste dia viria a coroar todo o movimento das atividades anteriores. A psicóloga especialista em trabalhar QVT com dinâmicas de grupo, a fim de encerrar as atividades do dia, coordenou a formação dos dois círculos de pessoas para que a dança circular tivesse início.

Esta dinâmica é realizada em empresas diversas e, tal como os "produtos" anteriores, independe do contexto local.

Após formado o círculo, passamos a seguir as ordens da líder. Desde que cumpríssemos as ordens, éramos iguais. Iguais enquanto liderados, enquanto subalternos que executam. O ritmo da música indicava a cadência do movimento, a consultora indicava a direção. A cada batida rítmica da música, dávamos um passo à direita ou à esquerda conforme indicação. O círculo interno foi instruído a girar para a esquerda enquanto o círculo externo a girar para a direita. Ao bater de palmas da líder, invertíamos as direções. Comandos eram apresentados para demonstrar a hora de dar um passo para trás, aumentando o círculo, ou para frente, diminuindo-o.

Ao passar de alguns minutos, todos já respondíamos sem que ordens verbais fossem dadas, bastavam palmas simples, duplas, levantar de mãos da líder etc. A movimentação rítmica foi aprendida pelo corpo de forma automatizada, coisa comprovada com o fato de que "parar para pensar" fazia a pessoa errar o movimento. Se, por acaso não tivesse sido possível escutar a palma ou ver o comando, bastava imitar todos os demais. Após um tempo que eu não saberia quantificar exatamente, 
mas, a pensar pelo final, deveria ser de mais de vinte minutos dançando, ninguém errava, ninguém demonstrava cansaço e todos riam e se divertiam. Agíamos igual, no mesmo ritmo, na mesma velocidade, na mesma direção. Dois círculos de pessoas de mãos dadas, um dentro do outro, girando em direções opostas conforme a batida da música: uma visão aérea poderia descrever como uma engrenagem humana. Este tipo de dinâmica dilui os conflitos porque dilui os sujeitos. Não restando nada além de uma massa disforme e rítmica, todos "dançam o mesmo passo", literalmente. 


\section{2) Treinamento: Vida Ativa - 0 jogo da qualidade de vida.}

O RH-Group, para este encontro, convidou uma empresa especializada em eventos e elaboração de programas corporativos de qualidade de vida no trabalho para organizações. A apresentação das atividades deste dia foi realizada por Selma (uma das coordenadoras do RH-Group) e foi explicado aos participantes que o pedido feito a esta empresa era o de levar ao RH-GROUP um treinamento igual ao que levam às empresas que os contratam. Foram então apresentadas aos presentes quatro consultoras da Vida Consultoria.

Estas consultoras se destacavam de todos os presentes por vestirem calças de moletom, camisas de algodão (com o logotipo da empresa) e sapatilhas sem salto. Este modo de se vestir destacava de forma simbólica a dimensão do "confortável" e era absolutamente destoante do modo de se vestir dos presentes, pois estes, em sua totalidade, estavam vestidos de trajes sociais, tais como tailleurs e ternos.

As consultoras Ana, Clara, Tânia e Sofia se apresentaram e explicaram que fariam uma apresentação da empresa em forma de palestra, com uso de slides e, após cerca de 30 minutos, dariam início ao treinamento propriamente dito.

A empresa possui pouco mais de 10 anos de existência e foi aberta por profissionais formadas em Educação Física e Esporte. Segundo a fala de Ana, baseada no portfólio da empresa:

"Com o compromisso de estimular o estilo de vida saudável nas empresas, utilizamos metodologia personalizada de ações para a Promoção da Saúde e da Qualidade de Vida no trabalho, promovendo o aumento da satisfação dos funcionários, maior produtividade do capital intelectual (crescimento do indivíduo em suas saúdes: física, emocional, intelectual, profissional, financeira, espiritual e social) e o fortalecimento da imagem das empresas." (Ana)

Ana ainda ressaltou a Missão e Visão da empresa:

"Missão: Promover a qualidade de vida pelo desenvolvimento e atuação de programas em saúde física, emocional, social, intelectual, espiritual, financeira e profissional proporcionando reflexões e ações práticas para a evolução do ser humano." (Ana) 
"Visão: Ser referência nacional em soluções de Qualidade de Vida. Manter-se referência nacional por meio da excelência em qualidade, inovação em todos os programas, velocidade e ética em um ambiente de crescimento e satisfação no trabalho, partindo do bem-estar em todas as relações." (Ana)

Esta empresa possui 4 áreas de atuação: Consultoria, Gestão de Pessoas, Saúde e Qualidade de Vida e Atividades Sócio-Culturais.

Na área de Consultoria, realiza "Coaching em Qualidade de Vida no Trabalho", orientando "metas individuais/grupo em qualidade de vida no trabalho" (Tania) e realiza também "Diagnóstico do Perfil de Qualidade de Vida no Trabalho", com entrevista, perfil de estilo de vida individual e desenho do projeto de qualidade de vida.

Segundo material da empresa distribuído aos participantes e lido por uma das consultoras, a Vida Consultoria possui diversas áras de atuação com produtos e serviços próprios:

\begin{tabular}{|c|c|}
\hline \multicolumn{2}{|r|}{ Atuação em Gestão de Pessoas } \\
\hline Produto/Serviço & Descrição \\
\hline Danças Circulares & $\begin{array}{l}\text { definida por eles como "São danças de roda, recolhidas de } \\
\text { diversas partes do mundo em diferentes períodos que possui } \\
\text { como objetivo principal a meditação ativa" }\end{array}$ \\
\hline Jogos Cooperativos & $\begin{array}{l}\text { desenvolvimento da reflexão para o trabalho em equipe, } \\
\text { cooperação, autopercepção e raciocínio }\end{array}$ \\
\hline Palestras & Informações, aperfeiçoamento técnico e conscientização \\
\hline SIPAT & $\begin{array}{l}\text { Organização, apoio e atuação da Semana Interna de } \\
\text { Prevenção de Acidentes }\end{array}$ \\
\hline Treinamento Indoor & Reflexão, integração e conhecimento cognitivo em sala \\
\hline Treinamento Outdoor & $\begin{array}{l}\text { Vivências experimentais ao ar livre com foco de } \\
\text { desenvolvimento pessoal e profissional }\end{array}$ \\
\hline
\end{tabular}




\begin{tabular}{|c|c|}
\hline \multicolumn{2}{|c|}{ Atuação em Saúde e Qualidade de Vida } \\
\hline Produto/Serviço & Descrição \\
\hline Academia Corporativa & $\begin{array}{l}\text { Consultoria personalizada de acordo com } \\
\text { a realidade da empresa }\end{array}$ \\
\hline $\begin{array}{l}\text { Levantamento de Estilo de Vida / } \\
\text { Avaliação Física }\end{array}$ & $\begin{array}{l}\text { Ferramenta utilizada para determinar a } \\
\text { situação atual e/ou progresso pessoal } \\
\text { individual ou em grupos dos pontos } \\
\text { fortes e fracos em relação às sete } \\
\text { dimensões da Qualidade de Vida }\end{array}$ \\
\hline Ergonomia / Fisioterapia do Trabalho & $\begin{array}{l}\text { Atendimento preventivo ergonômico e } \\
\text { clínico para a manutenção da saúde e } \\
\text { melhoria da Qualidade de Vida }\end{array}$ \\
\hline Massoterapia & $\begin{array}{l}\text { Utilização de diversas técnicas em stands } \\
\text { montados nas empresas, em eventos etc }\end{array}$ \\
\hline Intervenções Laborais & $\begin{array}{l}\text { Ginástica laboral em atividades } \\
\text { informativas e vivenciais realizadas } \\
\text { através de uma pausa no ambiente de } \\
\text { trabalho }\end{array}$ \\
\hline Semana da Saúde & $\begin{array}{l}\text { Semanas especiais personalizadas } \\
\text { baseada em diversos temas de Saúde } \\
\text { Preventiva }\end{array}$ \\
\hline Intervenção Nutricional & $\begin{array}{l}\text { Atendimento personalizado de } \\
\text { reeducação e adaptação alimentar }\end{array}$ \\
\hline Treinamento de Corrida & $\begin{array}{l}\text { Treinamento personalizado e } \\
\text { acompanhamento em provas de corrida } \\
\text { de rua }\end{array}$ \\
\hline
\end{tabular}




\begin{tabular}{|c|c|}
\hline \multicolumn{2}{|c|}{ Atividades Sócio-Culturais } \\
\hline Produto/Serviço & Descrição \\
\hline Atividades/Vivências na Natureza & $\begin{array}{l}\text { Vivências ao ar livre que utiliza de forma } \\
\text { sustentável o patrimônio natural e } \\
\text { cultural }\end{array}$ \\
\hline $\begin{array}{l}\text { Eventos } \\
\text { Comemorativos/Esportivos/Recreativos }\end{array}$ & $\begin{array}{l}\text { Promoção, Organização e coordenação } \\
\text { das atividades voltadas à integração e } \\
\text { ludicidade personalizada para datas } \\
\text { especiais }\end{array}$ \\
\hline Grêmio Corporativo & $\begin{array}{l}\text { Administração geral e interatividade com } \\
\text { os colaboradores da empresa }\end{array}$ \\
\hline
\end{tabular}

Sobre o treinamento que seria realizado no RH-GROUP, afirmaram que consistia em um dos principais diferenciais da empresa, pois era um jogo criado por eles e baseado nas "Sete Saúdes", concepção que falaremos mais adiante.

Foi explicado que o formato do treinamento buscava, de forma expositiva e vivencial, utilizar de Andragogia (definida por eles como a aplicação de trocas de experiências, relatos, compartilhamentos e vivências) e visando a conscientização, pelos participantes, das Sete Saúdes.

"O objetivo do jogo é vivenciar as sete saúdes da vida por meio de escolhas e decisões do grupo. Os participantes terão contato com situações diversas $e$ gerenciarão suas emoções, expandindo seus conhecimentos e habilidades, sua consciência física, a qualidade dos relacionamentos, a satisfação da escolha profissional, material e o propósito de vida." (Clara)

Segundo as consultoras, os objetivos do treinamento eram:

- Ampliar a consciência sobre o tema Qualidade de Vida no Trabalho;

- Inteligência comportamental para um estilo de vida mais saudável;

- Reconhecer as limitações a respeito da qualidade de vida e traçar um plano de metas para lidar com as adversidades em cada saúde. 
Um importante pilar para este tipo de proposta de intervenção é a definição de Qualidade de Vida da Organização Mundial de Saúde:

"Conjunto de percepções individuais de vida no contexto dos sistemas de cultura e valores em que vivem, e em relação às suas metas, expectativas, padrões e preocupações" (O. M. S.)

Esta definição é particularmente importante para este tipo de proposta, pois ambicionando respeitar as diferenças culturais, acaba por apresentar um texto onde o cerne da questão da qualidade de vida é o "conjunto de percepções individuais". Não é à toa que uma empresa que elabore um treinamento "para indivíduos" se embase nesta definição. Se a avaliação pessoal da qualidade de vida está definida em torno da percepção individual, pode-se criar um sofisma onde a afirmação "fazer o indivíduo perceber mais positivamente sua situação de vida é melhorar sua qualidade de vida" ganha lugar. Neste caso, o sofisma generaliza o perceber a realidade como abrangendo também a realidade representada. Trazer esta definição abre caminho para treinamentos onde melhorar as condições de trabalho não são necessárias, pois basta trabalhar na valoração interpretativa que o indivíduo faz das condições de trabalho dadas.

A apresentação da empresa e das propostas do treinamento que ainda seria realizado estava sendo acompanhada por uma apresentação em slides. Após comentar da definição da OMS, o próximo slide era unicamente a afirmação:

"Qualidade de Vida = Escolhas de Bem-Estar"

Esta afirmação remete a questão da qualidade de vida à dimensão individual. Qualidade de vida seria, portanto, uma questão pessoal. Ao mesmo tempo em que a fala das consultoras acerca desta fala "dava poder" aos sujeitos, afirmando que era da alçada de cada um a qualidade da vida dentro e fora do trabalho, no trabalho, na família etc (Ana), dialeticamente esta fala responsabilizava os sujeitos pela situação na 
qual se encontravam. Se eles têm o poder de mudar, o fato de nada mudar é tão somente fruto das "escolhas" de cada um.

O próximo slide, onde se afirmava: "A MUDANÇA é uma porta que só pode ser aberta pelo lado de DENTRO - Marilyn Ferguson" (slide da Consultoria Vida) situa o indivíduo isolado como sendo o lugar de onde se partem ações, uma fala onde se desresponsabiliza a empresa, o Estado etc. Afirmando que a "Saúde Total" só pode ser atingida mediante "Atitudes, Conhecimentos e Comportamentos" (Ana), citando Ogata ${ }^{18}$ e de Marchi, apresentou parte da pesquisa destes onde se afirmava que os aspectos que envolviam a capacidade de permanecer saudável eram distribuídos da seguinte forma:

- $5 \%$ condições ambientais

- $10 \%$ cuidados médicos

- $15 \%$ circunstâncias sociais

- $30 \%$ carga genética

- $40 \%$ escolhas comportamentais

A última linha, referente às "escolhas comportamentais", era muito destacada das demais mediante tamanho de fonte duas vezes maior e fonte na cor vermelha. Importante notar que esta informação apresenta o fato de que as escolhas comportamentais são mais importantes estatisticamente do que os cuidados médicos, as condições ambientais e as circunstâncias sociais somadas.

Antes de explicar quais as "Sete Saúdes" que embasavam o treinamento, o último slide buscou situar a empresa no mercado da qualidade de vida no trabalho:

“Com o compromisso de estimular o estilo saudável nas empresas, a metodologia personalizada das ações de qualidade de vida no trabalho da VIDA promove o aumento da satisfação dos funcionários, maior produtividade do capital intelectual (crescimento do indivíduo em suas dimensões: física, emocional, intelectual, profissional, financeira, espiritual e social) e o fortalecimento da imagem da empresa." (slide da Consultoria Vida)

18 Alberto Ogata é médico, mestre em medicina e economia da saúde, presidente da Associação Brasileira de Qualidade de Vida (ABQV) 
A Consultoria Vida em Qualidade de Vida no Trabalho criou um conceito de qualidade de vida que descreve o homem em sete categorias, chamadas de Sete Saúdes: Espiritual, emocional, social, física, intelectual, financeira e profissional.

\begin{tabular}{|c|c|}
\hline Saúde Espiritual & $\begin{array}{l}\text { busca "o encontro com a missão e propósito de vida, baseando-se } \\
\text { em crenças e valores. Entusiasmo com a própria vida" }\end{array}$ \\
\hline Saúde Emocional & $\begin{array}{l}\text { "aprimoramento da resiliência humana por meio do gerenciamento } \\
\text { das emoções, mediante o uso da inteligência emocional, auto- } \\
\text { estima e auto-consciência e pelo gerenciamento do estresse" }\end{array}$ \\
\hline Saúde Social & $\begin{array}{l}\text { "reflete na qualidade dos relacionamentos interpessoais, dedicação } \\
\text { ao lazer e contribuição com a comunidade e com o meio ambiente" }\end{array}$ \\
\hline Saúde Física & $\begin{array}{l}\text { "atividade física, alimentação equilibrada, repouso adequado e } \\
\text { comportamento preventivo, a saúde física está refletida na } \\
\text { capacitação individual para práticas saudáveis e no bem-estar } \\
\text { físico" }\end{array}$ \\
\hline Saúde Intelectual & $\begin{array}{l}\text { expansão permanente do conhecimento e das habilidades, estando } \\
\text { presente na busca de conhecimentos, desenvolvimento de } \\
\text { habilidades e capacitação cognitiva. }\end{array}$ \\
\hline $\begin{array}{l}\text { Saúde } \\
\text { Profissional }\end{array}$ & $\begin{array}{l}\text { "Estar satisfeito com sua escolha profissional, trabalhando em um } \\
\text { bom clima e ambiente. Inclui a satisfação no trabalho, o } \\
\text { reconhecimento profissional e o clima e ambiente profissional" }\end{array}$ \\
\hline Saúde Financeira & $\begin{array}{l}\text { "gestão das próprias finanças, ganhar um salário que corresponda } \\
\text { às suas expectativas e um modo eficiente de gastar e economizar" }\end{array}$ \\
\hline
\end{tabular}

O treinamento realizado em forma de jogo corporativo almeja promover a conscientização das sete saúdes, propiciando aos participantes maior autonomia e conhecimento para realizarem escolhas de bem-estar. Este treinamento, portanto, é dirigido a sujeitos e não a organizações, segundo sua concepção.

"O objetivo do jogo é vivenciar as sete saúdes da vida por meio de escolhas e decisões do grupo. Os participantes terão contato com situações diversas e 
gerenciarão suas emoções, expandindo seus conhecimentos e habilidades, sua consciência física, a qualidade dos relacionamentos, a satisfação da escolha profissional, material e o propósito de vida" (slide de apresentação do treinamento)

Finalmente, pediram que nos dividíssemos em grupos de oito participantes, de preferência com integrantes que não fossem nossos conhecidos. Afastadas as cadeiras e aberta uma grande área para circulação das pessoas, os grupos foram dispostos ao redor da sala e, no centro, foi colocado um número muito grande de material a ser utilizado. Cada grupo recebeu uma pequena lousa suspensa por um tripé e deveria pegar, no montante deixado no meio da sala, elementos que pudessem compor um personagem. No centro da sala havia centenas de imãs, tal como imãs de geladeira, só que maiores, com figuras de roupas, sapatos, jaquetas, ternos, rostos e etc, de forma que fosse possível montar na lousa de metal um personagem. Dentre outro bolo de imãs, estavam dispostos elementos de consumo, como imãs de carros, notebooks, livros, celulares e diversos utensílios eletrônicos.

Outro material foi então distribuído para cada grupo: tratava-se de um disco de acrílico dividido em sete pedaços, tipo uma pizza, onde cada pedaço dizia respeito a uma das saúdes citadas. Em cada pedaço havia um indicador numérico, de 1 a 10, que deveria ser utilizado para indicar "quantos pontos" o personagem tinha naquela saúde.

Após cada grupo passar algum tempo escolhendo roupas e acessórios para o personagem, num clima muito distraído, e estabelecendo pontos para cada uma das saúdes do personagem, as consultoras pediram para que cada grupo pegasse uma carta de um baralho feito especialmente para este jogo. Cada carta possuía uma combinação de pontos para cada saúde, como, por exemplo: Saúde financeira: 8 pontos, Saúde física: 3 pontos, e assim por diante.

Cada grupo precisou adaptar seu personagem à carta retirada. A primeira explicação dada até agora, após o início do jogo, era que o primeiro personagem era o nosso sujeito ideal, mas precisávamos lidar com um sujeito real, com problemas e desníveis entre as saúdes. 
O jogo, a partir desse momento, passou a se constituir na busca de pontos para se colocar no personagem. Porém, havia mais um baralho de cartas com informações a serem seguidas.

O primeiro grupo a retirar a carta encontrou a informação: "Para todos os grupos: Ganhe 2 pontos para a Saúde Física, criando um jingle para vida saudável." A consultora instruiu-nos, neste momento, a criarmos um jingle em 2 minutos e cantarmos para toda a sala. Caso aprovado, o grupo ganharia os pontos e esta atividade deveria ser realizada por todos os grupos.

Meu grupo, composto por 4 funcionárias de RH de empresas diversas, 1 professor de administração e integrante de uma consultoria e um consultor independente, rapidamente formou um pequeno círculo e começou a pensar no tema. Três integrantes já começaram a cantar jingles prontos. Perguntei se tinham conseguido pensar naqueles versos rapidamente, mas uma funcionária de $\mathrm{RH}$ respondeu, rindo, que já teve que passar por situações similares diversas vezes e já sabia "tudo que costuma aparecer de inesperado em treinamentos" (Sonia). Arnaldo, consultor, comentou que sabia uns 15 jingles de tanto que já teve que inventar e se espantou por eu não estar acostumado a este tipo de jogo.

Eu comentei que não tinha tido que inventar jingle, pelo menos ainda, e nesta hora uma das funcionárias me incumbiu de inventar o jingle. Afirmei que o Arnaldo tinha dado uma boa sugestão com a música que havia cantado, mas outros 2 participantes disseram que como eu não tinha passado por isso ainda eu precisava aprender, porque uma hora ou outra eu seria cobrado por uma coisa dessas. Afirmei que não "levava jeito" pra isso, e argumentaram que esse era justamente o motivo de aproveitar um "treinamento de mentira" para aprender a passar por isso, principalmente pelo fato de não haver um chefe me observando e nem estar disputando um emprego. O grupo inteiro decidiu que eu sozinho inventaria um jingle e o cantaria frente aos demais, pois somente eu não sabia ainda como era esta experiência.

Interessante notar que, apesar do clima de descontração do treinamento ser notável, este momento onde o grupo me elegeu como protagonista da atividade demonstra a seriedade do mundo do trabalho onde este tipo de evento está inserido. Se em momento algum se fala do trabalho propriamente dito, ele subjaz a experiência 
daqueles que estão participando do treinamento. Conforme ficou claro na fala dos participantes do grupo, um treinamento "de brincadeira", mesmo que orientado para a qualidade de vida, não deixa de ser um momento onde se treina. Contudo, mais que uma ação específica, treina-se um modo se ser específico deste espaço discursivo das novas formas de gestão. Neste exemplo, um certo saber-ser criativo (Fleury \& Fleury, 2000). Também se percebe, neste exemplo, que mesmo um treinamento sendo estruturado de forma a desenvolver a competitividade nos participantes, o fato dos integrantes do meu grupo me elegerem como protagonista não deixava de ser um ato de solidariedade, visto que queriam que eu desenvolvesse uma resiliência própria de treinamentos como este, ou seja, que eu ficasse mais capaz de sobreviver a estas experiências.

Com a ajuda do grupo, um jingle sobre a "saúde física" foi inventado e cada grupo passou a cantar e encenar seu jingle. Caso os outros grupos aplaudissem, o grupo ganharia os pontos. Foi nítido o "profissionalismo" do jingle de alguns grupos. A cena consistia em profissionais de ternos e roupas sociais, sentados ao chão, cheios de apetrechos coloridos e se esforçando (e se divertindo) muito em cantar suas versões. Comentei dentro do meu grupo que achava que as pessoas estavam gostando de criar e cantar, e Sonia, uma das funcionárias de RH, comentou rindo: “Ninguém gosta, é constrangedor. Aqui é fácil porque é tipo uma brincadeira, mas no trabalho não é tão fácil. Precisa engolir a vergonha e se fazer aparecer".

Todos aplaudiam os outros grupos, de forma que todos ganharam pontos.

O jogo continuou com alguns momentos onde havia disputa entre grupos, como a consultora pedir "palavras que começam com a letra ' $T$ ' e que existe num escritório". O grupo ganhador levava os pontos e conseguia "deixar seu personagem mais saudável", enquanto que o grupo que perdia, perdia pontos e precisava escolher "qual saúde iria se enfraquecer". Aqui vemos nitidamente a relação entre competitividade e saúde, visto que, quando o grupo vence uma competição, o seu personagem fica mais saudável, enquanto que, ao perder, perde-se em saúde.

Algumas atividades só podiam ser disputadas por quem "tinha saúde financeira de 6 pontos ou mais", porque simbolizavam viagens e cursos de MBA, outras só pelos grupos que possuíssem saúde física maior que 7, para, por exemplo, correr uma maratona. Quando um grupo ganhava 4 pontos e decidia colocá-los somente na saúde 
espiritual, por exemplo, poderia se arrepender na rodada seguinte, pois precisavam de uma saúde intelectual maior para vencer algum desafio e, devido a isso, se arrependiam das escolhas feitas nas rodadas anteriores.

Enquanto um grupo competia com outro, perguntei aos integrantes do meu grupo se em algum momento as consultoras tinham comentado em que situações aplicavam esta dinâmica. Foi respondido, pelo consultor Nélson e por Camila que em qualquer situação elas podiam aplicar esta dinâmica. Eu comentei que elas estavam, segundo o pedido das organizadoras, tratando-nos tal como se fôssemos uma empresa que tinha pedido um evento em qualidade de vida no trabalho, mas eu gostaria de saber se éramos algum tipo de empresa em especial, pois as consultoras haviam comentado que faziam um trabalho personalizado para cada empresa. Os integrantes do meu grupo estranharam minha dúvida e Nélson perguntou se aquela dinâmica não servia para algum lugar, enquanto os demais, que acompanhavam a conversa, concordaram com ele.

Esta questão sobre "a especificidade da empresa" não fazia muito sentido para os integrantes do meu grupo e talvez não fizesse muito sentido também para a maioria dos presentes naquela sala. Neste tipo de situação, a dimensão trabalhada não é a do "trabalho propriamente dito", mas a da postura frente ao ambiente organizacional, exatamente como exposto pelo slide de apresentação que afirmava ser esta uma empresa "Com o compromisso de estimular o estilo saudável nas empresas (...) e o fortalecimento da imagem da empresa" (slide da Consultoria Vida).

Diferente da reunião sobre Gerenciamento do Stress, que tinha um objetivo ligado à saúde, este treinamento em forma de jogo corporativo tem um objetivo pedagógico. Situações de competição, estímulos à criatividade, dessensibilização à exposição e ao constrangimento. O trabalho em grupo, o uso de experiências estranhas ao ambiente de trabalho e as "escolhas saudáveis", enquanto estimulam certo estilo de vida "saudável", estimulam também outro estilo de vida associando-o à idéia de vida saudável. Além do estilo de vida saudável, este treinamento busca melhorar as aptidões (ou competências) dos presentes ao mundo que Gorz (2005) vai chamar de mundo do trabalho imaterial. 
"Essa é uma das grandes diferenças entre os trabalhadores de manufaturas ou de indústrias taylorizadas e aqueles do pós-fordismo. Os primeiros só se tornam operacionais depois de serem despojados dos saberes, das habilidades e dos hábiltos desenvolvidos pela cultura do cotidiano, e submetidos a uma divisão parcelada do trabalho. (...) Os trabalhadores pós-fordistas, ao contrário, devem entrar no processo de produção com toda a bagagem cultural que eles adquiriram nos jogos, nos esportes de equipes, nas lutas, disputas, nas atividades musicais, teatrais, etc... É nessas atividades fora do trabalho que são desenvolvidas sua vivacidade, sua capacidade de improvisação, cooperação. É seu saber vernacular que a empresa pós-fordista põe para trabalhar e explora. Yann Moulier-Boutang chama de exploração de segundo grau essa subsunção ao capital do trabalho coletivo como trabalho vivo, e não como poder da ciência e das máquinas" (Gorz, 2005, pp.19).

Gorz continua, afirmando que o trabalhador da "sociedade do conhecimento" deixa de se apresentar como um vendedor de mão-de-obra e passa a configurar um produto que ele mesmo precisa continuar a se auto-produzir. Os indivíduos não passariam mais a "interiorizar a cultura da empresa", mas, ao contrário, "a empresa é que vai, de agora em diante, buscar no exterior, ou seja, no nível da vida cotidiana de cada um, as competências e as capacidades de que ela necessita" (pp. 20).

A ausência de referência ao trabalho concreto realizado pela "empresa" que brincávamos ser não era sentido enquanto uma "falta" pois o treinamento não falava de trabalho. Este tipo de jogo corporativo faz sentido num ambiente onde o trabalho deixou de ser uma categoria central.

A associação entre treinamento "para uma vida mais saudável" e "pedagogia para uma empresa onde o trabalho não é categoria central", entretanto, não deixa de ser questionável. O sujeito que passa por este treinamento ampliaria sua consciência sobre as saúdes ao mesmo tempo em que se auto-produziria enquanto um produto melhor para a empresa com a qual "colabora". Juntar, num mesmo processo, a busca por uma vida mais saudável e o desenvolvimento para o trabalho imaterial acaba por associar estes dois movimentos.

O trabalho desta consultoria era sim "personalizado". De acordo com as possibilidades financeiras de cada cliente, montavam programas distintos. $\mathrm{O}$ trabalho era sob-medida, mas na medida de quanto se podia pagar. A Vida Consultoria havia montado diversas academias corporativas em diferentes empresas, organizado SIPATs e programas de ginástica laboral. O "sujeito", nesta configuração, se é que podemos 
chamar assim, é a figura da Empresa e não o trabalhador ao qual o programa visa atingir. Estes são tão apenas os objetos do treinamento.

Segundo Fleury \& Fleury (2000), as organizações que utilizam a Gestão por Competências devem desenvolver nos seus funcionários toda uma gama de novos modos de saber-ser: "saber agir, saber mobilizar, saber transferir, saber aprender, saber engajar-se, ter visão estratégica e saber assumir responsabilidades" (p. 30). 0 treinamento oferecido pela Vida Consultoria se insere nesta modalidade de Gestão, onde a postura do trabalhador, seu estilo de vida, possui importância fundamental para a corporação.

Desenvolver no trabalhador um modo de ser implica em dar um passo adiante ao vestir a camisa do Modelo Japonês, ou seja, apresenta uma intensificação do poder disciplinar (Foucault, 1997). A internalização da idéia de ser-saudável, presente em um treinamento orientado para a qualidade de vida no trabalho, busca moldar corpos que se apresentem de forma a demonstrar saúde. Neste sentido, a postura do sujeito, seus hábitos e desejos devem refletir a idéia de trabalhador saudável. $\mathrm{O}$ trabalhador passa a ser responsável pela sua saúde, de forma a desresponsabilizar a empresa e, ao mesmo tempo, treinado a demonstrar (e a sentir) que está saudável, independente das condições concretas de sua saúde. 
Capítulo 7 : Caso de um Programa premiado de QVT: bom para quem? 
Neste capítulo analisaremos uma entrevista realizada com uma consultora em psicologia organizacional e ex-funcionária do departamento de Recursos Humanos de uma empresa Benchmark em QVT.

Tereza é formada em Psicologia há quase 20 anos e, antes de se formar, estagiou na área de Recursos Humanos. Da empresa de informática, onde iniciou, foi trabalhar em uma grande rede de supermercados, de onde foi demitida devido a uma crise da empresa. Após a demissão, Tereza trabalhou no RH de uma empresa de assistência médica (cerca de três anos), em uma empresa de economia mista, ligada ao setor de saúde (quatro anos) e ajudou a implantar o departamento de RH na filial brasileira de uma grife de roupas.

Após quase 10 anos voltou à rede de supermercados Markets ${ }^{19}$ e trabalhou nesta empresa por cerca de oito anos, deixando-a para montar uma consultoria própria. Nesta empresa, Tereza atuou na área de Recursos Humanos e teve grande vivência sobre o Programa de Qualidade de Vida dos Trabalhadores desta, bem como um importante cargo neste próprio Programa.

Esta empresa é destacada no cenário nacional devido ao Programa de Qualidade de Vida e tornou-se referência dentre profissionais da área, bem como constantemente citada em artigos nacionais como um "exemplo a ser seguido". A possibilidade de entrevistar Tereza trouxe importantes questões para refletirmos sobre a ótica de quem trabalha dentro de um Programa de QVT de grande porte, como o citado.

Tereza voltou à Markets em 1990 e conheceu o Programa de QV desde sua implantação. "Então, assim: quando foi implantada a questão da qualidade de vida, os

\footnotetext{
${ }^{19}$ Nome alterado por questão de sigilo.
} 
símbolos mais fortes foram a alimentação e a ginástica." A academia de ginástica para os funcionários da Markets fica localizada na central da rede de supermercados. É justamente esta academia que virou o símbolo da qualidade de vida nesta empresa. A Markets possui "marcas próprias", que são marcas pertencentes ao grupo empresarial que é dono da cadeia de supermercados e houve uma grande publicidade deste Programa de QVT, segundo Tereza, pois associar a empresa à boa qualidade de vida dos seus trabalhadores significaria associar as marcas próprias à idéia de qualidade.

Segundo Tereza, a academia era considerada o "carro chefe" do Programa. Porém, logo depois de inaugurada, a academia precisava funcionar para dar continuidade à publicidade e aos artigos em revistas que suscitava, então houve uma pressão interna para que os funcionários a freqüentassem:

\begin{abstract}
"Inauguraram uma academia muito sofisticada e tinha assim, quase que uma imposição de que todo mundo tinha que fazer academia! (...) Era a maior estrutura... tinha fisioterapeuta... Mas era uma superestrutura e tinha mesmo uma exigência, mesmo, de todo mundo ir na academia, que era uma coisa que fazia parte da cultura lá da empresa..." (Tereza).
\end{abstract}

Segundo Tereza, ao invés de trazer uma possibilidade "a mais" de lazer e saúde, a academia acabou por Ihe trazer preocupações.

"No meu caso, eu não gosto, não tem nada a ver comigo puxar ferro ${ }^{20}$, mas eu fui tentar. Como eu morava na esquina, eu ia fazer às 6 h15 da manhã, porque aí eu vou na hora que não tem ninguém na academia! Porquê é complicado... eu era consultora interna, e eu estava lá na esteira e ao lado tinha alguém que era meu cliente! E aí, naturalmente, você acaba caindo numa situação de trabalho. Eu tinha a percepção de que eu estava trabalhando. E sempre assim..." (Tereza).

A pressão relatada para se freqüentar a academia não implicava em fazer exercícios na hora do expediente, logo, o funcionário acabava por permanecer mais horas dentro do prédio da administração central. Claro que, se a academia é algo "fornecido pela empresa" para melhorar a qualidade de vida destes, estes em nenhuma hipótese ganhariam horas extras para lá estar, pois já "ganhariam" melhor qualidade em suas vidas. Porém, permanecer de 1 a 2 horas num ambiente cheio de

20 "Puxar ferro" refere-se a fazer exercícios com pesos em academia. 
colegas de trabalho permitia que temas oriundos do trabalho viessem à tona. Segundo Tereza, era a mesma fórmula do "almoço de negócios", quando a pessoa não tem tempo para encaixar uma reunião, então simplesmente a realiza durante o almoço.

Enquanto "andava na esteira" ${ }^{21 ",}$ muitos colegas se aproximavam e conversavam de trabalho, perguntavam sobre andamento de projetos e outros assuntos. Tereza comentou que ficava uma "presa fácil" no equipamento, visto que, como não gostava de circular entre os aparelhos de musculação, pois não lhe agradava aquele tipo de exercício, a esteira Ihe deixava "andando sempre no mesmo lugar", o que facilitava a aproximação de colegas.

O cotidiano da academia começou a incomodar Tereza e, segundo ela, pessoas ligadas a ela. O dono da empresa havia passado por problemas pessoais ligados à saúde e como havia superado estes problemas ele gostava de ir à academia para "servir de exemplo". Devido a este fato, os diretores e executivos logo abaixo dele começaram a ir ao mesmo horário que ele, e isso gerou um "efeito cascata" que terminou por fazer com que diversas pessoas estivessem claramente indo à academia para ter contato com superiores hierárquicos com os quais não tinham contato normalmente.

O cotidiano foi tornando-se "pesado" e outros fatores, como a criação de um Programa de Incentivo e Motivação para os funcionários freqüentarem mais a academia, ajudaram a piorar a qualidade de vida dentro desta academia. Tereza conta que era possível saber quem ia bastante à academia e quem não ia, pois, após algumas presenças (Tereza não lembrava exatamente o número de dias por semana que era necessário ir) o funcionário ganhava uma bolsa para colocar suas roupas de exercício. Os funcionários que tivessem uma assiduidade maior ganhavam calças (as mulheres ganhavam uma calça tipo Leg feminina), mochilas, toalhas e havia também prêmios como camisas e etc.

A questão aqui é como estes elementos acabavam por funcionar como sinalizadores de assiduidade. Uma pessoa que freqüentasse muito a academia e ganhasse um cantil esportivo para colocar água, utiliza-o em diversos momentos, sinalizando que havia conquistado tal produto (que não era vendido). No ambiente específico desta empresa (mas não exclusivo dela) a competitividade estava sendo

\footnotetext{
21 "Andar na esteira” é o exercício no aparelho elétrico Esteira Rolante.
} 
valorizada ao máximo e elementos simples do cotidiano como estes sinalizadores acabavam por gerar um clima de disputa interna. Estas "medalhas" funcionam como parte deste mecanismo disciplinar que busca imprimir um certo estilo de vida a estes trabalhadores (claramente mais ligado à competitividade que à saúde propriamente dita).

Esta cadeia de supermercados começou, nesta época, a patrocinar atletas profissionais e amadores, bem como times inteiros de Vôlei, por exemplo. Esta estratégia de vincular a marca foi estabelecida dentro e fora da empresa ao mesmo tempo. Tereza comentou que novos espaços foram gradativamente sendo criados dentro da sede da Markets, como quadras de squash. Havia, disposto nos corredores dos andares, chamadas aos funcionários para participarem de torneios internos de ciclismo, squash, corrida e diversas modalidades, sempre com grande divulgação do ganhador como sendo "um grande vencedor".

Tereza comentou que um dos amigos dela na empresa chegou a se engajar num grupo de ciclismo aos domingos por conta de conseguir ficar mais próximo do chefe e conseguir uma promoção, porém, mesmo após "nem mesmo ficar longe do chefe aos domingos" (Tereza), este amigo foi demitido. Foi nessa época, também, que palestras motivacionais ligando o tema de qualidade de vida (dentro e fora do trabalho) a esportes de competição começaram a aflorar em eventos da empresa.

Este caminhar de um Programa de Qualidade de Vida no sentido de fortalecer corpos e mentes é bem diferente do que se poderia esperar de uma empresa fordista. Em uma empresa fordista, poderíamos pensar em um modelo (mesmo que cruel) de uma empresa que busca fortalecer e moldar corpos para o trabalho, de forma a conseguir o máximo de produtividade. Porém, a ideologia de competição, com esportes competitivos e campeonatos dentre os funcionários está focado num outro espectro, o de estimular os trabalhadores a "vestir a camisa da empresa" tal como um jogador apaixonado por seu time veste a camisa do clube: não estamos falando simplesmente de corpos para o trabalho, mas de entrega total de espírito para a empresa.

Tereza comentou que os funcionários sabiam inclusive quantos quilos cada diretor levantava no "supino", que é um exercício clássico de levantamento de peso. Neste movimento da empresa, onde os funcionários eram estimulados e 
recompensados por bons resultados nos esportes, os trabalhadores passaram a ser também "garotos propaganda" do quanto esta empresa seria saudável. A Markets, patrocinando maratonas de rua, por exemplo, estimulava seus funcionários a treinar forte para competirem nestas provas.

Sabia-se quantos quilos cada diretor levantava, e sabia-se também quem "não levantava nada". Para Tereza, este era o pior lado deste aspecto do Programa de Qualidade de Vida no Trabalho: o banheiro da academia.

"E outra coisa que me incomodava muito! Era a coisa do banheiro da academia, da exposição. É como um banheiro de clube, no caso das mulheres, só o box que era fechado, então você tinha que se trocar na frente de outras pessoas, muitas vezes seus clientes, pessoas com as quais você tinha uma relação profissional. A exposição do corpo, pra mim, era uma coisa que me deixava muito desconfortada." (Tereza)

Tereza comentou que as pessoas tentavam se trocar dentro do Box, porque este era fechado. Comentou isto como uma prova de que, além dela, muitas pessoas se sentiam desconfortáveis com a exposição. A exposição do corpo, em uma empresa que se engaja em tal proposta, traz pressões que não existiam antes deste Programa de Qualidade de Vida. Segundo Tereza, na hora de tirar uma blusa e mostrar que a pessoa está acima do peso, ninguém vê o quanto ela produz no trabalho, o quanto se dedica, mas apenas como está "sedentária, acomodada". A academia foi "se expandindo" e, quando saiu de lá, Tereza afirmou haver seis quadras de squash, com arquibancadas e outras coisas mais, com ampla divulgação de campeonatos e vencedores, porém, "tudo numa ótica de competição".

Siqueira (2004), analisando textos da revista Exame, conclui:

"elemento que nos chama a atenção no texto é a hipervalorização do esporte, sempre citado como prioridade, seja este a caminhada, o jogging, a academia de ginástica, o tênis, ou qualquer outro. $O$ executivo herói é também um esportista, um indivíduo que é vencedor também no esporte, que cuida da saúde e é feliz, envolvido dia e noite, com o trabalho e com o esporte. Observase, inclusive, o quanto o esporte vem sendo utilizado por executivos, inclusive na busca de uma melhoria de suas relações pessoais e no desenvolvimento de suas habilidades competitivas. A estrutura estratégica de grandes empresas, como bem acertadamente nos diz Enriquez (2000, p.29), valoriza e exige em 
seus quadros indivíduos que sejam ganhadores, esportistas, verdadeiros guerreiros que estejam dispostos a tudo pela vitória." (Siqueira, 2004, p. 109)

Siqueira continua sua análise, destacando que, em muitas empresas, há uma assimilação entre os perfis: executivo de sucesso e do esportista vencedor. Segundo esta ótica, os empresários devem estar atentos para o desempenho do executivo nos esportes, pois um vencedor "o é em todos os momentos", o que nos leva a deduzir a presença da idéia de vocação na mentalidade empresarial. Se o executivo, portanto, não se dedicar aos esportes com toda a "gana de vencedor que lhe é própria", caberia, então, duvidar-se dele.

Sobre outros fatores do Programa de Qualidade de Vida dos Trabalhadores da Markets, Tereza contou que houve uma série de medidas para tornar o ambiente de trabalho mais agradável. Uma modificação que foi apresentada e inicialmente elogiada foi o chamado Lanche Saudável:

"eles começaram a oferecer uma coisa que eu achei super sensacional, que era que você podia pedir no almoço, no meio da manhã e no meio da tarde, um "Ianche saudável". Pra cada um desses momentos, tinham duas opções. E já vinha descontado no seu holerite, no final do mês, e era mais barato. Isso era uma coisa que fez o maior sucesso, porque a pessoa que não tinha tempo de sair [para almoçar], ela pedia! E era uma fruta, um yogurte, uma barra de cereais, uma saladinha... Isso, pra mim, foi uma coisa que realmente fez diferença, foi muito bom. Só que assim, em última instância, era você quem pagava. Era um valor mais barato, mas você pagava." (Tereza).

Esta medida da empresa de supermercados de vender produtos para seus trabalhadores foi tida inicialmente como algo muito bom, por Tereza. Porém, o tempo se encarregou de mostrar que, se era possível pedir algo para se comer na mesa de trabalho, por outro lado, acabou ficando "mal visto" na empresa aquela pessoa que costumava sair para almoçar todos os dias. Como toda empresa que enxuga ao máximo seu quadro de funcionários e busca retirar de cada um a maior mais-valia possível, sempre havia "trabalho atrasado" e, se as pessoas à sua volta, da sua equipe, estavam almoçando na mesa de trabalho para não parar de trabalhar, esta ação do 
Programa de Qualidade de Vida dos Trabalhadores da Market acabava por pressionar o trabalhador que se dava ao luxo de fazer valer seu direito de horário de almoço.

Neste caso, poderíamos isolar o problema da seguinte forma: Trabalhadores da Markets não saíam de suas mesas para almoçar, durante o horário para tal. A solução do problema demonstra como este foi "interpretado" pela empresa: a solução não buscou fazer com que os trabalhadores saíssem para almoçar. A solução desta situação também não pensou em como diminuir a carga de trabalho das pessoas para que elas pudessem, sem constrangimentos nem pressões, exercerem seu direito de horário de almoço. O Programa de Qualidade de Vida dos Trabalhadores da Markets, ao contrário, pensou em como seria possível alimentar estes funcionários para que não parassem de trabalhar, e mais: vendendo seus produtos para estes. Desta forma, não bastava trabalhar na empresa que produzia aqueles produtos, mas era necessário também ser consumidor destes.

"E chegou um momento, depois de muito tempo, acho que em 2004, eu já estava na empresa fazia um bom tempo... eu falei: Não! Agora eu preciso sair pra almoçar. Porque você entrar às $8 \mathrm{~h}$ da manhã e sair, de repente lá pelas $9 \mathrm{~h}$ da noite, sem nem dar uma saída, é muito cansativo. Se você não sair, você tem uma sensação de cansaço muito grande. É diferente de você sair, uma horinha que seja, mas você vai dar uma volta pelo quarteirão... Você almoça e volta, eu acho que já dá uma quebrada." (Tereza).

Acerca das pressões específicas que sofre o profissional de Recursos Humanos que atua em um Programa de QVT, Tereza afirmou que são aquelas ligadas às expectativas dos funcionários que mais incomodavam. Segundo ela, o profissional de $\mathrm{RH}$ vira referência para os demais, principalmente aquele profissional que atua no Programa de QV e está orientado a buscar melhorar a qualidade de vida dos trabalhadores.

"É terrível! Nós tínhamos que entender tudo! Tínhamos que entender qualquer tipo de situação! A gente tinha que ser flexível... As pessoas que estavam acima de mim achavam que eu tinha que entender tudo, não podíamos questionar nada... E como você vai poder oferecer alguma alternativa de lidar com uma situação para alguém lá dentro se você está exposta à mesma cultura organizacional?" (Tereza) 
Após ingressar em um curso de $M B A$ interno, Tereza se viu amarrada ao papel

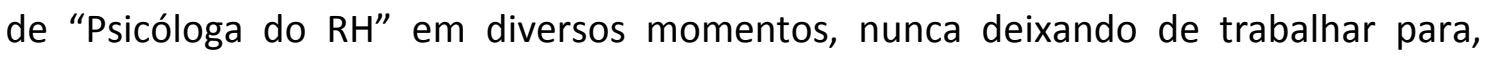
finalmente, se tornar "aluna" no curso. Lembrou-se de algumas pessoas que, repentinamente, choravam durante o curso ou ao término da aula, sempre resultando em ser chamada pelos demais alunos para os "acolher", visto que era "psicóloga do $R H^{\prime \prime}$. "No MBA interno que eu fiz e larguei, se alguém chorava, logo falavam: Tereza! Cadê a Tereza? A Tereza tem que socorrer!" Não por acaso, Tereza não conseguiu terminar o curso e o abandonou. É importante notar a afirmação de que é impossível fornecer uma alternativa a algum funcionário quando se está à mercê da mesma cultura organizacional.

Ao afirmar "o RH tem clientes, mesmo sendo clientes internos", Tereza não se descreve como sendo uma trabalhadora entre os demais, mas uma representante da empresa para seus próprios funcionários: "Eu me sentia muito desconfortável frente a alguns aspectos da empresa, que eu não concordava, mas como RH você tem que vender um peixe que você não comprou." (Tereza).

Sobre serviços diversos promovidos pelo Programa de QVT, foi comentado como a pressão sobre o profissional de $\mathrm{RH}$ acaba permeando espaços onde ele também deveria ser visto como um "funcionário qualquer, sujeito às mesmas pressões que todos" e merecedor do mesmo descanso e dos "benefícios" que o PQVT podia oferecer:

\begin{abstract}
"A questão da massagem era muito complicada porque as pessoas iam pra massagem, e muitas vezes tinha fila, e era uma coisa assim: eles davam só o espaço para o massoterapeuta trabalhar, a pessoa que pagava... e aí os massoterapeutas ouviam uma série de situações e eles passavam a ser detentores de um conhecimento, de até segredos institucionais... sabiam de coisas pessoais sobre as pessoas... era super complicado. Como eu ia com uma certa freqüencia, eu via que quando ia alguém do RH ele começavam a falar pra gente tomar providências porque as coisas estavam super pesadas, super complicadas! Ou seja, eu não tinha descanso!" (Tereza).
\end{abstract}

Tereza comentou que este foi o caso de quando trabalhou na área de Seleção do Markets, pois frente aos candidatos, ela deveria falar como se aquela fosse a 
melhor empresa possível, e, segundo a entrevistada, isso a fazia sentir-se mentindo para os concorrentes, o que tornou aquele trabalho insustentável.

Após permanecer na área de Recursos Humanos, Tereza foi para uma sub-área chamada de consultoria interna, onde deveria atuar junto a trabalhadores para verificar se eles estavam "assistidos em suas necessidades de recursos humanos". Contou que, nesta época, procurava passar o menor tempo possível no $\mathrm{RH}$, ficando a maior parte do tempo na "área dos clientes".

Após este período, foi convidada para uma área chamada Gestão de Executivos, setor que tinha um critério de faixa salarial para que o funcionário pudesse ter acesso aos programas desta área. Segundo a entrevistada, ela não queria ir para esta nova função, porém era a melhor decisão, pois estava se preparando para deixar a empresa. Afirmou: "Tínhamos um serviço de coaching interno e eu sabia que não funcionava... Coaching interno não funciona!" Quando questionada sobre o porquê desta ação organizacional não funcionar, Tereza foi enfática, novamente se remetendo à questão de estar situada no mesmo ambiente interno que o cliente: "Porque você está sujeito à mesma cultura organizacional que o seu cliente".

A explicação é clara: quais as possibilidades de um Coach, que, a priori, é um funcionário da empresa que atua com uma postura parecida com um terapeuta e orientador de carreiras, de ser sincero junto ao atendido? Tereza comentou que é impossível ser sincero, pois você precisa fazer a pessoa "render mais" e, na empresa Markets, havia um enorme agravante para o trabalho do Coach: "a demanda para um trabalho interno vinha através da chefia da pessoa", ou seja, quando um executivo não rendia o que seu chefe esperava, ele era "encaminhado" para o serviço de Coach.

Apesar de ser uma ação organizacional que possui como princípio teórico ajudar o executivo a desempenhar melhor suas funções e repensar seu momento na carreira, este encaminhamento só existia a partir de uma avaliação negativa da chefia sobre um funcionário, coisa muito diferente de quando alguém procura o trabalho externo de Coach para repensar seu momento na carreira e etc, pois neste caso há realmente sigilo profissional.

A situação torna-se análoga a do encaminhamento escolar. Se há algum rendimento abaixo do esperado e uma criança é encaminhada para atendimento 
psicológico, parte-se do pressuposto que o "problema" "está nela", o que de imediato compromete todo o processo de atendimento.

Para além de ser um "tiro que sai pela culatra", o serviço interno de Coach somente para executivos de uma determinada (e alta) faixa salarial servia também como desencadeador de conflitos nos demais setores, pois segundo Tereza, aqueles que não tinham acesso ao benefício o consideravam como disponível somente para aqueles que já têm muito e acabam tendo também ainda mais oportunidades.

A decisão de Tereza de se desligar da Markets envolveu uma análise de sua relação com a empresa e o planejamento de um "processo de saída", principalmente relacionado a toda uma série de serviços e benefícios que faziam parte do Programa de Qualidade de Vida para os Trabalhadores desta empresa:

"Tem algo que eu esqueci de dizer que é fundamental, que era o conjunto de opções internas que você tinha dentro da empresa... então você tinha lá dentro restaurante, cabeleireiro, massagista, academia, quadra de squash, vídeolocadora, revela-foto, banco e uma loja, como se fosse um supermercado, que vendia só o que eles chamam de marcas-próprias. Ou seja, se você bobeasse, você não saia de lá, manhã, tarde e noite! Então tinham pessoas que a vida toda delas estava lá! Então foram pessoas que, quando foram demitidas, não tinham vida própria! Porque não tinham nem um cabeleireiro perto de casa onde elas iam, porque estava tudo lá. Isso é muito complicado! Teve muitos momentos, no meu processo de decisão, que eu me sentia presa, então, antes, o que eu achava que era uma facilidade, tipo 'vou descer e vou fazer a unha', eu falava: 'Não! Eu prefiro ir mais longe!', porque isso parece que é um monstro de mil tentáculos que está me envolvendo!"

Siqueira (2004 p.158), afirma: "Assim, cada vez mais, as empresas vêm suprindo seus membros com todo o conjunto de serviços e necessidades que fazem parte da vida contemporânea". Chama esta complexificação organizacional de "Empresa Total" (p. 158). As fronteiras institucionais estariam sendo diluídas e a organização buscaria, cada vez mais, atrair para seu interior atividades que estão sob a esfera de outras dimensões sociais, por um lado para prover seus funcionários de tudo quanto consiga para mantê-los dentro de suas dependências, e, por outro, amarrando o trabalhador ao microcosmo institucional criado.

A fala de Tereza nos mostra, de forma drástica, como o Programa de Qualidade de Vida dos Trabalhadores, promovido pelo RH em que ela própria trabalhava, acabou 
por ser descrito como "um monstro de mil tentáculos". Esta seria, talvez, a dialética cruel de um programa de qualidade de vida aos trabalhadores de uma empresa com tal envergadura: De tanto esquadrinhar o cotidiano do trabalhador para descobrir "necessidades para suprir", um programa como este elabora um microcosmo na instituição e tende a aprisionar o indivíduo em meio a tantas "facilidades".

É a idéia de Empresa Total que melhor descreve este movimento ambíguo de providência e dependência. Uma empresa onde um funcionário é envolvido de forma gradativa até precisar planejar o desligamento da organização tal como se planejasse uma mudança de cidade.

\section{Convidando uma Consultora externa}

Quando esteve responsável pela área de Atendimento ao Cliente, composto por um Call Center, Tereza optou por contratar uma consultora externa para realizar alguns trabalhos junto aos trabalhadores desta área. Segundo a entrevistada, esta área era tida como um problema, pois era onde havia a maior rotatividade de trabalhadores.

O setor tinha uma chefia que trabalhava "com pulso firme" desde o início da empresa. A vinda da entrevistada para esta área coincidiu com a morte desta pessoa, o que desestabilizou ainda mais a área.

A consultora contratada, segundo Tereza, era de confiança, pois havia trabalhado com pessoas conhecidas e tinha ótimas referências. A opção de Tereza foi de dar "carta branca" para que ela pudesse realizar a atividade que quisesse e com sigilo resguardado entre ela e as trabalhadoras.

A consultora elaborou uma proposta de dinâmica de grupo com um número de participantes limitado em cerca de 12 trabalhadores. Havia vários horários para os trabalhadores se inscreverem e era imprescindível, para Tereza, que a adesão fosse optativa, com sigilo entre a consultora e os participantes e realizada dentro do horário de trabalho.

A entrevistada afirmou ter "comprado algumas brigas" com a gerência devido ao fato da atividade ser realizada dentro do horário de trabalho dos funcionários. Interessante notar que a atividade ser elaborada prevendo sigilo sobre o que ocorresse 
em sua realização e permitindo a opção em não participar não foi problema para a gerência. Desde que "ninguém parasse de trabalhar" a atividade podia propor qualquer coisa. Justamente esta visão sobre o trabalhador enquanto mão-de-obra que precisa ser explorada, postura que não se interessa pelo trabalho que será realizado, é que permite brechas como esta que Tereza explorou: o sigilo entre os trabalhadores e a consultora.

Em última instância, claro, quem controla este sigilo é a própria Tereza, funcionária do Markets, porém esta buscou fazer o que podia para elaborar uma atividade junto a estes trabalhadores que permitisse desenvolver temas que só surgiriam caso o consultor não estivesse amarrado à mesma cultura organizacional que os outros.

A presença de uma cultura organizacional que privilegia o discurso do especialista (Chaui, 2006) abria a brecha para se chamar alguém que, apesar de desconhecer o cotidiano daqueles funcionários, poderia realizar um trabalho comprometido com os trabalhadores e não com o empregador, principalmente numa situação amparada pelo sigilo. A consultora, formada em Psicologia, tinha no Código de Ética de sua profissão o "amparo burocrático" para apresentar à empresa Markets o motivo do sigilo.

Dialeticamente, o mesmo discurso competente que tende a excluir a história como fator constituinte dos sujeitos foi que possibilitou este arranjo institucional.

Sobre os resultados do treinamento, Tereza afirmou que parecia ter feito com que aqueles trabalhadores pensassem sobre sua situação naquele trabalho, apesar da rotatividade ter se mantido alta e logo ela ter sido transferida de área.

Quando questionada sobre o que tinha acontecido durante as dinâmicas, como estas tinhas se desenvolvido, Tereza afirmou: "Eu não sei." Tereza afirmou isto com nítido orgulho, como se esta fosse a prova de ter tentado criar uma bolha de reflexão não disciplinada pela empresa.

Claro que o fato de ela não saber implica em limites dados ao trabalho realizado, porém, neste caso, parecia que a proposta era justamente criar este espaço para reflexão sobre o trabalho, mesmo que não fossem mexer no trabalho propriamente dito, mas, pelo menos, possibilitar, de alguma forma, mesmo que precária, um espaço "não tão controlado". 
Neste caso, Tereza utiliza da ambigüidade (Sato, 1997) do discurso que valoriza a contratação de consultores especialistas no assunto para poder desenvolver alguma atividade que não estivesse limitada às práticas daquele ambiente, ou seja, que pudesse trazer algo novo para o setor. 
Capítulo 8: A Empresa ESB ${ }^{22}$

${ }^{22}$ Nome fictício, bem como os nomes dos contatos na empresa e o nome da sub-área pesquisada, que também foram alterados para garantir respeito às questões éticas envolvidas. 


\section{1) Caracterização Geral da Empresa ESB}

A ESB está presente em vários municípios do Estado de São Paulo. Fundada há mais de 30 anos, atualmente é uma Empresa de economia mista e capital aberto, possuindo como principal acionista o Governo do Estado de São Paulo. Possui ações no mercado, presentes na Bolsa de Valores de São Paulo (Bovespa) e de Nova lorque.

Visando garantir que as ações da empresa estejam efetivamente alinhadas ao direcionamento estratégico definido no seu processo de planejamento, desde 2005 a ESB vem implementando o Balanced Scorecard (BSC), uma ferramenta de gestão que avalia o desempenho da organização sob quatro perspectivas: 1) financeira; 2) dos clientes; 3) dos processos internos; 4) do aprendizado e crescimento.

Pesquisar uma empresa de grande porte como a ESB envolveu a escolha de uma sub-área que permitisse ao pesquisador estar presente junto ao cotidiano. No caso desta empresa, a sub-área escolhida foi a Área Tec, a qual descreveremos a seguir.

\section{Caracterização da área Tec}

A área Tec é especializada em desenvolvimento de tecnologia orientada para 0 tipo serviço empreendido pela ESB e possui cerca de 350 funcionários que trabalham em ambiente predominantemente administrativo. Dentre suas atribuições, destacamse o desenvolvimento de pesquisas junto a engenheiros da empresa, cursos internos 
para qualificação de técnicos e encarregados, bem como a administração de cursos em convênios com parceiros internacionais.

Algumas áreas da ESB, pelo tamanho do quadro de funcionários, precisam - por lei - ter todo o quadro de prevenção à saúde do trabalhador, o SEESMT |(Serviços Especializados em Engenharia de Segurança e Medicina do Trabalho), que, segundo Bete, é composto por um médico, um enfermeiro e um engenheiro de segurança do trabalho. Segundo esta analista de $\mathrm{RH}$, a Tec, por seu tamanho, só precisou de um engenheiro de segurança, locado no RH da $\mathrm{Tec}^{23}$.

A área Tec, por sua vez, possui um núcleo próprio de Recursos Humanos, o TecRH, com cerca de 30 funcionários.

Após a troca de Presidente da empresa, ocorrida juntamente com a mudança de Governador do Estado, a sub-área TecRH passou a ser questionada pela nova chefia central quanto à necessidade da existência de um Departamento de RH particular a um núcleo - a Tec - e o porque de não se remeterem à Superintendência Geral de RH como as outras áreas fazem.

Conversas com trabalhadores desta sub-área permitiram vislumbrar o clima tenso vivido pelos funcionários deste lugar que corria o risco de ser extinto. É importante salientar que, em um momento de questionamento da necessidade de existência do setor, passou a ser criado um Programa Local para Qualidade de Vida dos Trabalhadores da Tec. A importância em se pesquisar este programa, apesar da existência do programa global de QVT, reside na possibilidade de que esta proposta esteja instrumentalizada no sentido de ampliar a visibilidade do setor e, principalmente, na criação de demanda para a manutenção do $\mathrm{RH}$ desta área, visto que um Programa Local de QVT precisaria ser gerido por um RH setorial.

\footnotetext{
${ }^{23}$ Este engenheiro de segurança, Marcílio, foi entrevistado e voltaremos a falar dele adiante.
} 


\section{2) O Programa de Qualidade de Vida da ESB}

A ESB possui um programa global de QV, destinado a todos trabalhadores da instituição. Apesar de ser destinado prioritariamente aos funcionários, o nome oficial do Programa não é "Programa de Qualidade de Vida dos Trabalhadores", pois esta proposta empresarial almeja se expandir para ações junto aos familiares dos trabalhadores e à comunidade. Porém, a palavra "trabalhadores", junto ao nome do Programa, está presente nas falas dos funcionários da empresa, mostrando que, de fato, é para estes sujeitos que o Programa se destina.

No Código de Ética da empresa, encontramos:

"Saúde e Segurança no Trabalho:

A empresa, em parceria com os empregados e fornecedores é responsável pela saúde e segurança das pessoas que trabalham para a organização, por meio de atitudes responsáveis no cumprimento de leis e normas internas relativas a Medicina e Segurança do Trabalho de forma a preservar os trabalhadores em um ambiente sadio e com qualidade de vida no trabalho."

Nesta explanação do Código de Ética encontramos a afirmação de que o compromisso é com a Qualidade de Vida no Trabalho.

O nome deste Programa chama-se "Viver Feliz: Programa de Qualidade de Vida da ESB". O Programa foi apresentado em dois diferentes momentos, por pessoas diferentes localizadas em áreas diferentes da ESB. Primeiro, em uma reunião com Bete, analista de RH da sub-área Tec, e depois, em um segundo momento, durante uma visita à Associação ESB, entidade mantida por trabalhadores da instituição e que coordena algumas atividades junto aos setores de Recursos Humanos da ESB para promoção de Qualidade de Vida aos Trabalhadores. A Associação ESB é oficialmente parceira da ESB na realização do Programa, e nela fomos recebidos por Débora, a responsável pela QV dentro da entidade.

O "Viver Feliz" foi tema de um Manual para os trabalhadores da ESB ficarem a par das atividades desenvolvidas. Um programa desta natureza, de abrangência total da empresa, é coordenado pela Superintendência de Recursos Humanos. 
O Programa Viver Feliz é uma ação da atual presidência da instituição, buscando "amarrar" (Bete) várias ações institucionais que eram desenvolvidas pela empresa, para melhor acompanhamento e avaliação dos seus resultados, e também organizar algumas equipes de funcionários para a promoção da QVT. No início do Manual, encontramos um texto chamado "Palavra do Presidente", onde ele afirma, dentre outras coisas:

“É com grande satisfação que estamos dando início ao PROGRAMA DE QUALIDADE DE VIDA DA ESB, uma iniciativa conjunta da empresa com a Associação ESB, que tem como maior objetivo a construção de um ambiente de trabalho com produtividade, qualidade de vida e bem estar (...) É por isso que, mais do que simplesmente apoiar o PROGRAMA DE QUALIDADE DE VIDA DA ESB, é de fundamental importância que todos se envolvam diretamente" (Manual Viver Feliz, p. 6).

O Programa de QV da ESB não se destina somente ao seu corpo de trabalhadores, mas tem, em sua proposta, o intuito de se expandir aos familiares dos funcionários e também desenvolver atividades junto à comunidade. As ações relativas à comunidade merecem atenção, pois se o programa de qualidade de vida não se destina exclusivamente aos trabalhadores, ele pode ser uma ferramenta aos trabalhadores mesclada com uma proposta de marketing junto aos consumidores, numa busca de associar o nome da empresa à "marca" de vida saudável, conforme comentário de uma funcionária entrevistada, Marta.

Institucionalmente, o Programa Viver Feliz possui definições próprias nas categorias Visão, Missão, Objetivos, Conceito de Qualidade de Vida para a ESB e Público Alvo.

Programa de Qualidade de Vida da ESB

\begin{tabular}{|c|l|}
\hline \multirow{2}{*}{ Visão } & $\begin{array}{l}\text { Ser uma empresa com diferencial em qualidade de vida, } \\
\text { consolidando a cultura advinda da conscientização para hábitos } \\
\text { saudáveis de vida e ambiente de trabalho voltado para as pessoas. }\end{array}$ \\
\hline Missão & $\begin{array}{l}\text { Encorajar e apoiar hábitos e estilos de vida que promovam a saúde } \\
\text { e o bem-estar entre todos os funcionários e familiares, ajudando-os } \\
\text { a encontrar o equilíbrio entre corpo e mente, de forma a } \\
\text { alcançarem o sucesso profissional e a felicidade pessoal que }\end{array}$ \\
\hline
\end{tabular}




\begin{tabular}{|c|c|}
\hline & assegurem valor agregado em tudo que se faz na Organização. \\
\hline Objetivos & $\begin{array}{l}\text { - Possibilitar aos funcionários melhor QUALIDADE DE VIDA, } \\
\text { dentro e fora da empresa. } \\
\text { - Oferecer oportunidade de mudança de cultura, quanto à } \\
\text { importância de se ter uma melhor QUALIDADE DE VIDA. }\end{array}$ \\
\hline Conceito de QV & $\begin{array}{l}\text { Obter o bem-estar das pessoas no ambiente de trabalho, família e } \\
\text { na sociedade em que convivem, a partir de esforços conjuntos da } \\
\text { empresa e dos funcionários. }\end{array}$ \\
\hline Público Alvo & $\begin{array}{l}\text { - Funcionários } \\
\text { - Familiares } \\
\text { - Comunidade }\end{array}$ \\
\hline
\end{tabular}

Alguns elementos certamente chamam a atenção nesta apresentação institucional do PQV da ESB. Primeiro, a descrição deste programa interno segue todo um roteiro normalmente encontrado para descrever uma empresa. A ESB possui uma explanação própria acerca de sua missão, valores e etc. O PQV possui, por sua vez, toda uma apresentação tal como se fosse também uma empresa com objetivos próprios, missão, valores e tudo mais. A impressão gerada é que o Programa de Qualidade de Vida da ESB possui existência paralela à instituição ESB.

Neste sentido, não é de se estranhar que esta apresentação pouco remeta ao tipo de negócio específico da empresa ou mesmo à especificidade do trabalho exercido por seus funcionários, mas detenha-se explicitamente em falar de "hábitos saudáveis" e "estilo de vida". A concepção que subjaz a criação de um programa ligado mais a hábitos e a estilos de vida do que ao trabalho concreto, ou, como afirma Gorz (2005), ligado ao sujeito do trabalho imaterial, permitiu que este Programa fosse elaborado por analistas de $\mathrm{RH}$ que o pensaram enquanto visitavam outras empresas de caráter absolutamente diferente desta.

$\mathrm{Na}$ "Visão" do PQV destaca-se o intuito deste Programa: tornar a ESB "uma empresa com diferencial em qualidade de vida". Por "visão", define-se uma descrição daquilo a que se espera atingir em um futuro de médio prazo, e ao afirmar que a visão do PQV é "Ser uma empresa com diferencial em qualidade de vida (...)" fica claro que 
este programa parece mais destinado à Empresa do que aos Trabalhadores, no sentido de agregar valor à marca. Não se espera simplesmente melhorar a qualidade de vida dos funcionários, mas o objetivo é fazer que esta empresa se destaque das demais quando levantada a questão da promoção de "hábitos saudáveis".

Acerca da "Missão", a empresa espera "encorajar hábitos e estilos de vida que promovam a saúde e o bem-estar entre todos os funcionários e familiares". Cabe perguntar o quanto este tipo de "missão" não parece "ousado demais", visto que à empresa não se espera atribuir tais poderes, que, conforme apresentado pela descrição do programa, não são simples: encorajar hábitos e estilos de vida. Por mais que exista toda uma cultura sobre hábitos saudáveis, é notável uma ação organizacional que assuma para si esta tarefa, não somente sobre seus funcionários, mas também sobre a família destes.

A descrição da "missão", ao afirmar: "ajudando-os a encontrar o equilíbrio entre corpo e mente", imputa aos trabalhadores um suposto desequilíbrio entre corpo e mente ao mesmo tempo em que opta por apresentar-se como a instância institucional que vai ajudá-los a resolver tal (suposto) problema. Ainda, ao apresentar-se como uma instituição que vai ajudar os trabalhadores, os responsáveis pelo Programa apresentam-se como não estando sujeitos aos desequilíbrios aos quais os trabalhadores estão, ou seja, tal apresentação faz com que destoem da apreensão geral de trabalhadores da empresa, tal como se fossem agentes externos.

A “missão" ainda afirma que toda esta proposta almeja ajudá-los a "alcançar o sucesso profissional e a felicidade pessoal que assegurem valor agregado em tudo 0 que se faz na Organização". Ou seja, não basta o sucesso profissional e a felicidade pessoal, a não ser que esteja assegurada agregação de valor "em tudo o que se faz na Organização" - seus produtos.

Com o "objetivo" de "possibilitar aos funcionários melhor qualidade de vida, dentro e fora da empresa", este Programa se coloca para os trabalhadores, mas pretende fazer-se presente muito além da situação de trabalho.

O "Conceito de QV" disposto na apresentação, por sua vez, deixa clara a ambição desta iniciativa corporativa: "Obter o bem estar das pessoas no ambiente de trabalho, família e na sociedade em que convivem, a partir de esforços conjuntos da empresa e dos funcionários". 
A apresentação do Programa remete, inicialmente, ao que Foucault conceituou como Biopoder. Foucault passa a elaborar as considerações acerca do biopoder devido ao desenvolvimento, no regime político-jurídico do liberalismo, da "arte de governar" ou "governamentalidade". Amparado pelo fenômeno da "estatização do biológico" (Bello, 2007), é exercido por uma lógica biopolítica que "mediante os biopoderes localizados, ocupar-se-á da gestão da saúde, da higiene, da alimentação, da sexualidade, da natalidade na medida em que esses sujeitos se tornam, no desenvolvimento do Estado moderno, coisas importantes para o poder" (Negri, 2003, p. 102 apud Bello, 2007).

Um questionamento a ser feito quando afirma-se que uma corporação está praticando ações relativas ao biopoder é sobre como é possível a uma empresa buscar exercer um poder de gerenciamento de saúde e vida que está associado tradicionalmente ao Estado? As propostas deste Programa, conforme poderemos falar detidamente acerca de cada iniciativa, "oficialmente" extrapolam os limites da empresa, buscando atingir não só seus funcionários "fora do horário de trabalho", mas suas famílias e à sociedade na qual estão inseridas.

Quando questionada sobre a participação de trabalhadores que não fossem da área de Gestão em RH na elaboração do Programa, Bete foi enfática: "Eles puderam participar sim! Olha o logotipo do programa... Fizemos um concurso aberto a todos os trabalhadores da ESB para inventarem um logotipo e divulgamos super bem o concurso. Teve uma premiação em dinheiro, mas não me lembro quanto foi. Muitos funcionários participaram e este foi o logotipo feito pelo ganhador" (Bete).

Nesta fala da analista da Tec, podemos entender que não houve efetiva participação dos trabalhadores na elaboração do Programa, para além do concurso acerca do logotipo. Obviamente seria um trabalho hercúleo buscar contemplar uma dimensão composta por um número enorme de trabalhadores, porém é de chamar a atenção a exclusão destes na elaboração de um Programa feito para melhorar suas vidas. É desta forma que Marta, funcionária há 20 anos desta instituição, encara a participação dos funcionários neste Programa. Segundo ela, há um maior interesse na apresentação do Programa à sociedade do que algo que seja realmente fruto de uma democracia interna. 
Questionada sobre os mecanismos de "diagnóstico" da ESB para saber quais as necessidades de seus funcionários no que tange à QVT, Bete afirmou que a empresa se baseia fortemente na Pesquisa de Clima Institucional realizada anualmente, sendo que em um ano é realizada uma consulta eletrônica via e-mail para todos os trabalhadores, contendo um questionário padrão acerca do dia-a-dia na organização, e, no ano seguinte, a mesma pesquisa é realizada mediante amostragem com um pequeno número de trabalhadores.

A ESB permite que as áreas criem programas locais para "complementar" (Bete) o Viver Feliz. Esta, talvez, possa ser considerada uma estratégia adotada para diminuir a distância entre um programa global para a totalidade dos trabalhadores e a particularidade de cotidianos locais.

O Programa de Qualidade de Vida da ESB é dividido em 4 módulos: Saúde, Lazer, Social e Integração e Módulo Segurança do Trabalho. A seguir, falaremos sobre a descrição oficial do programa, com informações cedidas pela analista de RH, pela gestora em RH e material produzido cedido pelos mesmos.

\subsection{1) Os módulos do Programa de QV “Viver Feliz"}

\section{a.) Saúde}

Dentro do Módulo Saúde existem 4 ações corporativas:

- Ação: PARE - Programa de Atendimento e Recuperação do Empregado

Possuindo como público alvo os funcionários que apresentam dependência química, objetiva conscientizar o funcionário portador desta dependência quanto à necessidade de mudança de comportamento e sobre o benefício da cessação do vício.

Dentre as atividades desenvolvidas, prevê proporcionar encaminhamento e tratamento em clínicas, com profissionais especializados credenciados, manter grupos de acompanhamento e tratamento individual e buscar envolver os familiares. 
- Ação: Prevenção e Controle do Tabagismo

Esta ação tem como público alvo todos os funcionários. Seus objetivos são: Harmonizar o ambiente de trabalho e o respeito mútuo entre os fumantes e nãofumantes; Encorajar e apoiar o direito a ambientes livres do tabaco, promovendo o bem-estar entre todos os funcionários; Atender as determinações legais; Estimular os funcionários à cessação do vício do fumo.

As atividades realizadas atuam no sentido de proporcionar apoio e encaminhamento para atendimento e tratamento individual aos fumantes, campanhas preventivas, restrição do tabaco no ambiente de trabalho e a proposta de envolver os familiares em campanhas contra o fumo.

A partir de 1 de julho de 2008, foi proibido o uso do tabaco em qualquer área dentro das instalações da ESB, obrigando os funcionários que desejassem fumar a saírem da empresa para tal. Esta foi uma "imposição do atual Presidente, porque ele queria que a ESB ganhasse um certificado chamado Selo Ouro, que é a empresa livre do tabaco" (Bete).

Nas conversas com funcionários, esta ação foi duramente criticada, inclusive pelos funcionários não fumantes e narrada como uma medida para "piorar a qualidade de vida"24 (Marta).

\section{- Programa Bem Viver}

Tendo como público alvo os funcionários de áreas administrativas e de atendimento aos clientes, esta ação objetiva a melhoria das condições ergonômicas através de adaptação das condições de trabalho às características individuais de cada funcionário, mediante ajuste eficiente, confortável, seguro e produtivo, incluindo máquinas, ferramentas, novos métodos de trabalho e organização de trabalho.

As atividades correspondentes estão catalogadas como: Avaliar a postura dos funcionários; Realizar ginástica laboral; Definir o "padrão ESB de mobiliário ergonomicamente adequado" (Manual Viver Feliz, p. 11).

\footnotetext{
${ }^{24}$ Retornaremos ao tema do combate ao fumo de forma específica adiante.
} 
Neste caso, repara-se que o objetivo "novos métodos de trabalho e organização de trabalho" não tem possibilidade de ser alcançado, pois as atividades elencadas para esta ação não tocam no objetivo citado.

- Ação Combate ao Stress

Nesta ação, os gerentes, funcionários de áreas administrativas e de atendimento aos clientes formam o público alvo.

Possui, como objetivos, "estimular e enfatizar a importância em investir no cuidado do corpo/mente/espírito, de forma que através do reconhecimento e avaliação da carga individual do stress possa definir meios para combater fatores negativos que estejam agredindo o corpo e a mente" (Manual Viver Feliz, p. 12).

Suas atividades propostas são: Identificar e acompanhar grupos potenciais de vulneráveis; proporcionar encaminhamento e tratamento clínico psico-terapêutico; Criar clube de hobbies; Incentivar atividades físicas.

\section{b.) Lazer}

- Ação: Incentivo às Atividades Físicas

Esta ação destina-se a todos os funcionários e familiares e objetiva a conscientização sobre a importância e os benefícios da atividade física para a saúde e prevenção de doenças e promover condições do funcionário realizá-la de maneira responsável. Objetiva também promover a integração entre funcionários.

As atividades referentes a esta ação envolvem a criação de programas locais de incentivos às atividades físicas, como caminhadas internas, yoga e ginástica, bem como a realização de campeonatos esportivos, clubes de caminhadas e corridas e o convênio com academias de ginásticas externas à ESB, visto que, em sua unidade central, já existe uma academia de ginástica coordenada pelo Grêmio dos Trabalhadores da ESB. 
- Ação: Incentivo às Atividades Culturais

Destina-se a todos os funcionários e objetiva promover o desenvolvimento pessoal dos funcionários através de atividades culturais e lúdicas, criando condições de redução de stress e melhorando o relacionamento interpessoal.

São atividades desta Ação: Realizar concurso literário e musical, promover o Coral ESB, realizar o sorteio de ingressos de teatro, cinema e demais espetáculos aos funcionários, quando existir contra-partida das leis de incentivo fiscal e estabelecer convênios com redes de cinemas e teatros.

\section{c.) Social e Integração}

- Ação: Campanha de Doações

Esta ação destina-se a todos os funcionários, familiares e comunidade, objetivando estimular entre os funcionários o espírito "solidário", refletindo diretamente na postura individual da motivação, como na responsabilidade social, adotada pela empresa, no que se refere ao voluntariado e doações à comunidade.

Esta dimensão do Programa de Qualidade de Vida Viver Feliz propõe a realização de campanhas esporádicas de doação, utilizando datas comemorativas como referência, como o "dia do doador de sangue", arrecadação de agasalhos durante o inverno, doação de brinquedos, por ocasião do dia das crianças e natal, alimentos na época de fim de ano e livros, na semana onde ocorre o dia mundial do livro.

- Ação: Integração Social

Destinada a todos os funcionários, busca promover a integração destes através de atividades temáticas que valorizam os profissionais que prestam serviços à empresa, contemplando e premiando os funcionários e familiares em datas e eventos especiais, quase sempre pela realização de sorteios durante os eventos. Segundo o manual do Viver Feliz, é objetivo desta ação "valorizar assim o conceito de qualidade 
de vida e a adoção de ações sociais". Segundo Bete, isto significa disseminar a idéia de que "viver melhor" vale à pena.

Prevê, como atividades, a realização de campanhas temáticas relacionadas às datas comemorativas com eventos e comemorações. Citam como datas fixas: Dia do Trabalho, Dia da Secretária, Dia da Mulher, dia de comemoração de profissões diversas e datas pessoais como aniversário dos funcionários, nascimento de filhos e falecimento de parentes próximos.

- Ação: Campanha de Alfabetização

Segundo o manual do Programa Viver Feliz, todos os funcionários e a Comunidade são alvos desta iniciativa, porém, segundo Bete, esta é uma proposta claramente voltada para o chão-de-fábrica da ESB, que conta com muitos trabalhadores de nível operacional, muitos sem a alfabetização completa.

A Campanha de Alfabetização é responsável pela realização de palestras locais sobre a importância da alfabetização, busca "erradicar o analfabetismo na ESB" (Manual Viver Feliz, p17) e estimular ações de alfabetização da comunidade, como ações sociais e voluntariado.

Responsabilidade da Superintendência de Recursos Humanos e Qualidade, esta ação está implantada oficialmente desde janeiro de 2008, porém não é uma dimensão do programa de qualidade de vida realmente implantada, segundo Bete. Segundo esta gestora, os trabalhadores não procuram requisitar estas atividades e não "geram demanda suficiente".

- Ação Campanha de Inclusão Digital

Destina-se a todos os funcionários com salário base de até $R \$ 1.500,00$ e busca oferecer condições ao funcionário de comprar um micro-computador, através de compra (financiamento ou doação), como também treinamentos e navegação na Internet. São buscados convênios com lojas de venda de computadores e também a disponibilização de salas de aula nas dependências da própria ESB com micros para treinamento voluntário nos softwares básicos e navegação na Internet. 
- Ação: Incentivo à preservação do meio ambiente

Constitui público alvo desta ação todos os funcionários, familiares e a comunidade. Busca incentivar, nestes sujeitos, o cuidado com o meio-ambiente mediante adoção de ações que priorizem a preservação da natureza.

Esta ação realiza a publicação de materiais informativos para seu público alvo, realiza concursos de desenhos e redação, com tema da campanha, junto a filhos de funcionários. Também promove, em parceria com entidades locais, campanha de plantio de árvores nas represas da ESB e em áreas públicas.

- Ação: Programa de Preparação para a Aposentadoria

Esta ação destina-se aos funcionários a até quatro anos da aposentadoria e tem como objetivo preparar os empregados aposentados por tempo de serviço ou por idade e empregados aposentáveis para a transição para a aposentadoria, possibilitando o desenvolvimento de um novo projeto de vida e "buscando elevar a auto estima" (Manual Viver Feliz, p.20).

Para atender seus objetivos, os coordenadores desta ação promovem a realização de palestras, cujos temas abordados são:

1. Atitudes que fazem a diferença

2. Finanças pessoais

3. Saúde

4. Empreendedorismo

5. Legislação previdenciária e cálculos de verbas rescisórias

Esta parte do Programa Viver Feliz está totalmente implantada e é coordenada pela Superintendência de Recursos Humanos e Qualidade.

\section{d.) Segurança do Trabalho}

- Ação: SIPAT - Semana Interna de Prevenção de Acidentes

Destinada a todos os funcionários. A SIPAT busca, segundo explicações de Bete e Rose, e também das informações dispostas no Manual Viver Feliz, conscientizar e 
informar sobre assuntos referentes à saúde, qualidade de vida e segurança do trabalho, visando à prevenção corporativa na manutenção de ambientes de trabalho seguros e saudáveis.

As atividades delimitadas nesta "Ação" restringem-se à realização de eventos corporativos de abertura e/ou encerramento da SIPAT e também pela premiação em concursos corporativos realizados durante a SIPAT. Esta restrição ocorre devido à existência de uma comissão interna, eleita pelos funcionários e baseada em disposições legais, que tem como responsabilidade (e direito) a coordenação da SIPAT.

- Ação: Minuto de Prevenção

Ação destinada a todos os funcionários, busca "conscientizar, através de orientação de segurança e saúde aos funcionários, visando à mudança de hábitos comportamentais" (Manual Viver Feliz, p.22).

Segundo Bete, o Minuto de Prevenção se apresenta no cotidiano dos setores mais industriais da ESB como um momento onde um chefe ou encarregado chama a atenção dos trabalhadores para si e explica alguma norma de segurança ou comenta algum fator de risco para os funcionários. Seria uma prática referente ao início dos turnos, ou algum momento específico, variando de setor para setor ${ }^{25}$.

As atividades "oficiais", segundo o Manual Viver Feliz, são: Elaborar e distribuir folhetos acerca das atividades de riscos e realizar a discussão e orientação dos funcionários, pelos gerentes ou encarregados de equipes, tendo como base este material impresso.

- Ação: Adote um amigo para proteger

O objetivo desta ação é abarcar a todos os funcionários e promover a prevenção/redução dos acidentes de trabalho, zelando pela saúde e segurança de todos. Para tanto, esta campanha buscaria promover uma organização informal dos

\footnotetext{
${ }^{25}$ A observação desta ação (presente dentro do Programa de Qualidade de Vida) é importante para esta pesquisa, pois, segundo as interlocutoras e o Manual indicam, parece ser esta uma medida contra o "comportamento de risco" mediante orientações para "acurar as percepções de risco" dos funcionários. Também é de se ressaltar que os folhetos são produzidos centralmente pela Superintendência, o que pode indicar uma subestimação das variações dos diversos cotidianos desta empresa presente em diversas cidades. Este tema é muito caro à Psicologia do Trabalho (Lima, A. B. \& Oliveira, F., 1995; Oliveira, F., 1997) pois retira o foco da prevenção de acidentes dos contextos de trabalho e o coloca nas percepções de risco individuais.
} 
trabalhadores, onde cada um se comprometeria a zelar pela segurança e saúde de um outro, orientando nas atividades, estimulando à realização de exames ocupacionais, etc. Segundo a analista Bete, essa ação "não pegou" e não é praticada no setor Tec, e, segundo seu relato, também não é praticada nos outros lugares da empresa em geral.

- Ação: Programa de Promoção à Vida - Campanha Melhoria do Ambiente de Trabalho

Esta Ação possui como público alvo todos os funcionários. Objetiva "estimular e capacitar os funcionários na identificação, qualificação e tratativa dos riscos existentes no ambiente de trabalho, visando à formação de cultura empresarial voltada à segurança e saúde ocupacional" (Manual Viver Feliz, p.24).

As atividades propostas por esta Ação dizem respeito a inspeções de segurança do trabalho dentro das unidades da ESB, envolvendo a premiação das áreas com melhores indicadores:

- Unidade nota 10: área com melhores condições de segurança do trabalho;

- Gerente nota 10: gerente mais comprometido com a segurança e saúde ocupacional de seus funcionários;

- Sugestão nota 10: funcionários que indicam melhorias que minimizem os riscos dos processos e atividades.

Esta Ação do Módulo Segurança do Trabalho é de responsabilidade da Superintendência de Recursos Humanos e Qualidade, constando no Manual como totalmente implantado.

Bete não soube explicitar exatamente quais as premiações e qual área, gerente e funcionários estavam sendo considerados "nota 10", porém comentou que esta é uma medida que visa prioritariamente as áreas mais industriais da empresa, e que uma medida estaria sendo elaborada para as áreas mais administrativas como a Tec, medida chamada "Inspeção Relâmpago". Segundo a analista, seria contratado um profissional da área de Ergonomia para circular dentre as áreas administrativas e fazer apontamentos individuais para os funcionários, desde correções posturais dos trabalhadores, até indicativos de alterações do ambiente, como altura dos monitores de computador e etc. 


\subsection{2) Sobre a "Mensagem Final" presente no Manual Viver Feliz}

Ao final do Manual Viver Feliz há um texto intitulado "Mensagem Final" sobre o qual consideramos interessante apresentar algumas de suas afirmações para posterior análise.

O texto inicia com a frase: "Mudar comportamentos não é uma tarefa fácil, mas é possível" (Manual Viver Feliz, p. 25, negritos nossos).

É argumentado, em seguida, que o "grande desafio" enfrentado por este Programa de Qualidade de Vida é justamente estimular o envolvimento de todos, e que esta tarefa é tanto da ESB quanto dos funcionários.

"É nossa proposta permitir que você atinja o equilíbrio emocional, através do aumento do bem-estar e qualidade de vida de todos, pois nossos funcionários são o maior diferencial para o sucesso de nossa empresa" (Manual Viver Feliz, p. 25)

A última fala do texto é também de grande importância para futuras análises que pretendemos realizar: "A Semente está lançada... Agora tudo é uma questão de ATITUDE!!!" (Manual Viver Feliz, p. 25, negritos originais).

A conclusão do Manual do Programa de Qualidade de Vida situa de forma clara e "oficial" o lócus de intervenção onde pretende operar: a consciência do indivíduo. Ao afirmar que seu interesse é "conscientizar" o sujeito, o que se pretende é que este internalize valores que a instituição julga indispensáveis para a "vida saudável". Aqui, encontramos a dimensão do poder que se pretende microscópico, pois "nãodetectável". É este o poder circunscrito no corpo do sujeito disciplinado e dócil e, por isso mesmo, passando de sujeito à assujeitado.

Aqui percebemos a contribuição de Machado (1979) apresentada na explicitação teórica desta pesquisa, quando o autor diz que a prática dos micropoderes opera um deslocamento tanto espacial quanto do nível de penetração na esfera pessoal dos sujeitos: há um deslocamento espacial do exercício do poder, visto que agora é a empresa e não mais o Estado que se preocupa em disciplinar os indivíduos, e também há uma mudança relativa ao nível de operação, que foi da coerção externa ao nível pessoal, onde os procedimentos técnicos de poder realizam um controle 
detalhado, minucioso do corpo - gestos, atitudes, comportamentos, hábitos e discursos.

O discurso sobre a qualidade de vida é apropriado pela organização que nele (no discurso) se faz sujeito ao apropriar-se dos enunciados referentes à governamentalidade da vida (Foucault, 2005). Esta prática de poder, por sua vez, cria novos sujeitos, que são os "personagens" de constituição cindida entre corpo e mente, descritos no Programa Viver Feliz, necessitados de uma ajuda (que só pode ser externa) a ser oferecida pelos operadores do Programa de Qualidade de Vida citado. É este o momento clássico onde a teoria foucaultiana afirma que os sujeitos são criados pelo discurso, pois estes trabalhadores cindidos e carentes de ajuda, genealogicamente falando, simplesmente não existiam antes deste Programa corporativo.

Apesar de ser criado pelas possibilidades discursivas, porém, este sujeito não deixa de ser histórico, pois a apropriação do discurso que configurou estes trabalhadores enquanto objetos do conhecimento (e do tratamento) do PQV se deu de forma específica neste momento histórico e não se daria da mesma forma em outros momentos, visto que os agentes que se apropriaram dos discursos possuem interesses diferentes em situações e épocas diferentes ${ }^{26}$.

\footnotetext{
${ }^{26}$ Ressaltamos este processo histórico-discursivo pois é comum a crítica de que Foucault "se esqueceu da história" ou "abandonou a história", segundo Araújo (2008) e Machado (1979).
} 


\title{
8.3) O Programa Local de Qualidade de Vida da área Tec
}

O Programa de Qualidade de Vida criado por Rose e Bete é fruto de uma parceira entre o RH da Tec, o qual Rose é gestora, e pela Gestão de Empreendimentos da Tec, onde Bete é analista. Apesar de Rose ser gestora e Bete ser analista, neste projeto as duas são parceiras sem degraus hierárquicos entre si. Segundo Rose, Bete está oficialmente encarregada de coordenar o Projeto Tec Feliz.

Oficialmente, o objetivo do deste Programa é:

\begin{abstract}
"Implementar e fortalecer o PQV Corporativo, procurando integrar ações voltadas ao bem estar visando à 'saúde total' segundo várias dimensões: Física, Emocional, Intelectual, Espiritual, Profissional, Social e Material" (Fonte: Slides da Apresentação Interna do Programa)
\end{abstract}

Em sua definição, consta que o Programa procurará implementar:

\footnotetext{
"Ações práticas que podem impulsionar, comprometer e melhorar o desempenho dos empregados, tendo como pano de fundo aspectos subjetivos no 'Reconhecimento e Valorização'” (Fonte: Slides da Apresentação Interna do Programa)
}

Conforme apontamos ao explicitar a parte do Manual Viver Feliz relativa à "Palavra do Presidente", no Programa Global está prevista a importância de que "todos se envolvam diretamente" (Manual Viver Feliz, p. 6). Neste Programa Local, fala-se agora em "comprometer" o trabalhador. Segundo Abreu (2004), o termo "comprometimento" vem substituir o termo "envolvimento", pois refere-se a um acirramento da relação de subordinação presente em uma relação. Antes, segundo o autor, falava-se em envolvimento, porém, com o aumento da competitividade e da necessidade de exploração, passou-se a falar-se em comprometimento, termo que, ao contrário do anterior, remete à irreversibilidade da relação estabelecida.

A referência ao desempenho do funcionário é crucial, pois, no parágrafo citado, é o desempenho e não a saúde o que parece ser o principal foco deste programa. 
A iniciativa interna do $\mathrm{RH}$ da Tec, entretanto, é focada nos temas Saúde e Segurança dos seus funcionários.

A elaboração do Módulo "Promoção à Saúde" compreende inicialmente o "mapeamento do perfil de saúde e estilo de vida dos empregados Tec" (Bete). Segundo a analista, não faz sentido algum para ela pensar sozinha em algumas iniciativas para os funcionários da Tec, se ela não sabe do que eles precisam. O mapeamento é necessário para levantar quais demandas podem ser supridas pelo programa, para que depois se pense nas ações corporativas que dêem conta da necessidade real dos trabalhadores.

Esta afirmação de Bete sobre o programa apresenta uma preocupação em construir um plano de ação que seja ligado ao cotidiano dos funcionários locais. A preocupação com o mapeamento nos coloca frente uma abordagem mais concreta dos trabalhadores, quando comparada com a prática anterior em se contratar treinamentos prontos, sem a realização de algum trabalho anterior para a verificação do quão adequado àquele setor o evento seria.

A gestora de $\mathrm{RH}$ comentou que os "eventos anteriores eram alheios ao nosso mundo", porém, como alguns eventos eram realizados por contratos centralizados, ela, enquanto gestora do Departamento de $\mathrm{RH}$ da Tec, não podia intervir na negociação.

Ao relembrar a gestão do presidente anterior, quando o indicativo da diretoria era justamente a contratação de consultorias para realização de eventos de Treinamento e Desenvolvimento (inclusive os ligados à QVT), Bete afirmou "É... com o novo Presidente, a gente não pode mais contratar um pessoal pra vir fazer eventos (...) Agora a fonte secou e temos que reduzir gastos, foi até meio difícil conseguir verba pra chamar a consultoria que vai mapear o pessoal da Tec."

Mesmo explicitando a preocupação com relação ao mapeamento dos trabalhadores e suas demandas, para não construir um Programa sem sentido para seu público alvo, Bete mantém a preferência pela contratação de uma consultoria que possa fazer este mapeamento. Talvez aqui tenhamos uma proposta almeja maior contato com o cotidiano dos trabalhadores, porém retida ainda numa prática cristalizada na empresa, a de considerar que o melhor para todos é chamar "quem entende do assunto". 
Aqui encontramos, portanto uma contradição entre discurso e prática. 0 Programa deve ser ligado ao contexto cotidiano dos funcionários, e, para abordá-lo, chama-se alguém que não faz parte ou mesmo conheça este cotidiano. Neste sentido, mesmo a troca de Presidente, onde ocorreu a saída de um mais "político" e a "entrada de um pragmático" (Rose), troca esta com encaminhamentos e indicações institucionais quase opostas, não possibilitou o desaparecimento de práticas e saberes que vêm ocupando o espaço há tempo. Aqui lembramos Spink (1996) ao percebermos a ESB justamente como um fenômeno psicossocial cuja dinâmica cotidiana resiste por meio de práticas e saberes cristalizados pelo setor de $\mathrm{RH}$ às novas mudanças e encaminhamentos do atual Presidente.

Não afirmamos, com isto, que os setores de uma organização sejam enrijecidos e imutáveis, mas tão somente que uma ordem vinda de cima para baixo não muda um cotidiano de uma só vez, inclusive porque a ordem é, ela mesma, interpretada e apropriada pelo setor, para somente depois este buscar cumpri-la.

Segundo a Ata da Reunião de apresentação da Programa Tec Feliz para validação pela alta administração, a primeira proposta interna do Programa é composta por 3 etapas:

1a Etapa: Mapear o perfil dos 350 empregados, através de contratação de consultoria especializada;

2a Etapa: Elaborar o Plano de Ação com base no mapeamento realizado pela consultoria;

3a Etapa: Implementar o Plano de Ação.

Segundo Bete, são prováveis medidas do Plano de Ação para a Promoção de Saúde:

1. Vigilantes do Peso

2. Saúde da Mulher

3. Palestras e Publicações Periódicas

4. Vacinações

5. Encaminhamentos para profissionais especializados 
A segunda proposta para a Promoção da Saúde diz respeito à Ação P.A.R.E Programa de Atendimento e Recuperação do Empregado. Esta Ação buscará “oferecer conceitos básicos de dependência química e capacitar os profissionais a identificar, abordar, encaminhar e reintegrar os empregados com problemas quanto ao desempenho". Cabe aqui a pergunta se serão somente os empregados com problemas quanto ao desempenho que serão alvos desta iniciativa, pois é o que a redação do texto sugere. Quando questionada a respeito, Bete afirmou que não havia percebido esta questão, mas concordava que somente é "perceptível", dentro de uma empresa, algum problema pessoal de algum funcionário quando este lhe limita o desempenho profissional. Esta ação do Programa de Qualidade de Vida Local da Tec, portanto, apesar de remeter-se aos problemas relacionados ao vício químico, pragmaticamente é uma ação de melhoria de desempenho, visto que é este o critério para colocar-se a "máquina para funcionar".

Esta proposta também está dividida em 3 etapas:

1a Etapa: Disseminar o Programa P.A.R.E. aos gerentes da Tec, através de contratação de consultoria especializada

2a Etapa: Disseminar o Programa P.A.R.E. aos empregados da Tec por mão de obra própria.

3a Etapa: Realizar permanentemente campanhas informativas e orientativas aos empregados da Tec (álcool, drogas e tabaco), por mão de obra própria.

Percebemos, na apresentação desta proposta do Programa Tec Feliz, novamente a prática de se buscar o auxilio de "consultoria especializada" para ajudar o Departamento de RH a lidar com seus "clientes internos", porém, há aqui uma característica diferenciada: $\mathrm{O}$ RH, com esta proposta, apresenta dois planos de ação diferentes para o seu público alvo. Optaram por contratar uma consultoria especializada para lidar com os gerentes, enquanto que os "empregados" serão abordados pelo próprio RH. Nota-se que ao diferenciar "gerentes" de "empregados", como se os primeiro não fossem também empregados da ESB, a apresentação do Programa descreve voltar-se para duas "categorias diferentes" de trabalhadores, onde uma será abordada por "quem entende do assunto" e a segunda "por mão de obra própria". 
A terceira proposta do Programa, ao ser apresentado à alta administração, diz respeito ao Módulo Integração e Social. Neste caso, o Programa Tec Feliz buscará reforçar a Ação corporativa do Viver Feliz condizente com a comemoração de datas especiais (nascimento de filhos, aniversário, casamento, dia das mães e dia dos pais) e datas pessoais (como falecimento de empregados e de parentes).

A quarta proposta ainda diz respeito ao Módulo Social e Integração e chama-se Expo Tec. O intuito é a realização de uma feira de exposições sobre as atividades da Tec para que os funcionários possam trazer familiares e mostrar-lhes os programas desenvolvidos pela área. Em termos de Qualidade de Vida do Trabalhador, esta Ação busca aprimorar o reconhecimento profissional do funcionário junto à sua família e à comunidade, porém, a importância deste evento extrapola a preocupação com a qualidade de vida. Conforme comentamos anteriormente, a troca de Presidente da ESB trouxe novas aflições aos funcionários alocados na Tec, principalmente o questionamento da necessidade da existência de um RH nesta área. A Expo Tec, institucionalmente, funcionaria como uma "janela" para que este setor torne público aquilo que faz, lutando, assim, pela sua própria existência enquanto área.

Em um dos slides da apresentação, ao descrever a Expo Tec, foi mostrado em grande destaque: "Valorização do Profissional Tec". Neste caso, a busca de reconhecimento junto à comunidade seria, com efeito, uma busca de valorização perante o restante da própria empresa.

Dentro do Módulo Segurança, encontramos a quinta e última proposta deste Programa setorial de Qualidade de Vida. Esta Ação também está dividida em 3 etapas: 1a Etapa: Promover reuniões com o SEESMT da Tec, para mapeamento das condições e riscos das unidades desta área, visando também conhecer e avaliar os indicadores de segurança do trabalho dos empregados.

2a Etapa: Elaborar plano de ação com base no mapeamento.

3a Etapa: Implementar plano de ação.

A proposta do Programa Tec Feliz apresenta também as ações complementares: Acompanhar e divulgar o Programa de Qualidade de Vida Viver Feliz, assegurar um Plano de Comunicação eficaz para tornar públicas as ações do Departamento de $\mathrm{RH}$, bem como intensificar a divulgação do e-mail do RH-Tec. 
Novamente temos aqui indícios da necessidade em se publicizar as ações deste setor de Recursos Humanos. 


\section{4) Sobre a "Qualidade de Vida" na Tec}

Segundo a gestora de RH Rose, o cotidiano da Tec está tenso e sofre grandes pressões, internas e externas, e a isto soma-se o grande volume de trabalho no setor.

Com a troca da direção da Empresa, foi proposto um enxugamento do Departamento de RH da Tec, havendo a requisição de que o Dr. Pedro (Diretor da Tec) conversasse com outros diretores para saber qual a demanda das outras áreas a fim de enviar trabalhadores para lá.

Nesta questão, segundo Rose, surgiram alguns conflitos sobre diferentes posições dos trabalhadores acerca das pessoas a serem transferidas. No relato de Rose, esta vem sendo a pior parte do processo de mudança das regras na ESB.

Rose comentou que podia ter pedido para sair do cargo de gestora, deixando de ter uma série de problemas e pressões, comentando: "Eu podia ter saído daqui e aí nunca teria desmarcado com você, ia estar numa outra área, com tempo pra te ajudar a conhecer tudo isto aqui", mas em seguida explica que prefere ficar ali, pois é nesta função que ela vê sentido no trabalho que realiza. Comentou que podia ficar como um dos "elefantes-brancos" ${ }^{27}$, mas julga ser incapaz de fazer isso num ambiente que existem pessoas sobrecarregadas à sua volta.

Sobre a própria qualidade de vida enquanto trabalhadora da ESB, Rose comentou que aquilo que lhe tira as energias é seu grande envolvimento com a função, porém, se ela parar de se envolver pra tentar mudar algumas coisas, ela considera que sua qualidade de vida enquanto trabalhadora irá piorar, pois irá ser uma "parasita".

Para Rose, o fato de não poder escolher com quem deseja trabalhar em grupo consiste numa grande fonte de stress. Aqui, vemos surgir um tema caro à Psicologia do Trabalho, onde a possibilidade de auto-organização do trabalho está atrelada à saúde do trabalhador (Sato, 2002), ou seja, atrelado à própria qualidade de vida.

Quando questionada sobre o quanto ela considera que um Programa de Qualidade de Vida dos Trabalhadores pode ser eficaz, ela buscou referência nas suas próprias palavras sobre o cotidiano de pressões da Tec. "O que mexe com a gente são

\footnotetext{
${ }^{27}$ Termo usado para se referir ao trabalhador que ganha um alto salário dentro da instituição, porém está alocado numa função considerada "sem grandes preocupações" pelos demais.
} 
essas questões subliminares que algo oficial não vai pegar, não vai e nem pode citar, porque são coisas que não podem virar oficiais".

Após parar um tempo para pensar, Rose deu um outro exemplo muito forte sobre fatores do cotidiano que não podem ser alvo de ações institucionais justamente porque seriam "oficializados". Neste momento, Rose contou sobre a chamada "Turma dos irregulares".

A ESB, há cerca de 20 anos, admitiu cerca de 1.000 funcionários, porém, há alguns anos, o Ministério Público julgou inválidas estas contratações, entrando com uma ação judicial para que fossem anuladas. Segundo Rose, a ESB nunca fez nada a respeito, chegando ao ponto de agora, em última instância, obrigar a ESB a demitir todos os funcionários que estão nesta situação, sem qualquer direito trabalhista. Segundo ela, a ESB podia ter feito concursos para regularizar este pessoal, comentando que isto acontece em muitos lugares, dando-se preferência para os que já trabalham e etc, porém nada disso ocorreu e agora existem muitos funcionários beirando uma situação de pânico.

A gestora comentou que todos sabem que "cabeças irão rolar". Ainda segundo Rose, o Ministério Público estaria dando um tempo para a ESB pedir uma negociação, "algo como: Mandaremos 100 pessoas embora por ano, para não comprometer os serviços essenciais, ou algo assim, mas nem isso a ESB fez, porque há toda uma luta em não jogar a toalha, porém é algo que pode acabar prejudicando a todos, pois o Ministério Público pode exigir a demissão imediata, por exemplo" (Rose).

Dentro da Tec, segundo a gestora de $\mathrm{RH}$, há alguns trabalhadores nesta situação e todos os outros acabam sentindo a angústia e se afetando também. Os que estão ameaçados não têm conseguido realizar seu trabalho direito, estariam sempre tocando neste assunto e, por vezes, algumas pessoas choram no ambiente de trabalho devido à tensão desta situação.

Rose, enquanto gestora de Recursos Humanos da Tec, comentou que tentou elaborar uma atividade dentro do Programa de Qualidade de Vida focada no sofrimento destes trabalhadores em questão, porém, não pôde dar continuidade porque uma ação institucional que reconheça a situação destes trabalhadores e busque ampará-los provavelmente seria utilizada posteriormente contra estes próprios funcionários, pois futuramente o Programa seria considerado como uma 
"preparação para o desligamento", e os funcionários atendidos seriam os primeiros a ser demitidos.

Este caso, para Rose, é emblemático das limitações de um Programa Institucional de Qualidade de Vida dos Trabalhadores. Existe um problema claro no setor, trabalhadores com visível sofrimento e nada pode ser feito, pois ao invés de ajudar, acabaria piorando ainda mais a situação dos funcionários.

Se, por um lado, o Programa de Qualidade de Vida da sub-área Tec cria demanda para sua própria existência, sendo ao mesmo tempo sujeito e objeto de uma iniciativa corporativa, criando-se enquanto sujeito ao se apropriar dos enunciados relativos à qualidade de vida dos trabalhadores, por outro lado, este setor não pode utilizar esta "máquina criativa" junto aos funcionários acusados de situação irregular. A estes cabe não ser nem mesmo objetos do programa, pois a criação destes enquanto um "público alvo específico" os alçaria à existência de "sujeitos degradados", tornando-os mais facilmente alvo para ações administrativas. 


\section{5) O limite e a contradição do PQVT: a "Turma dos irregulares"}

A situação dos funcionários conhecidos como "Turma dos irregulares" foi citada pela primeira vez durante uma conversa com a gestora Rose. Em uma posterior conversa com Marta, houve a sugestão de se entrevistar algum funcionário deste grupo, bem como em uma conversa de corredor, fomos, num dado momento, abordados por Sandra que, ao saber sobre o tema da pesquisa realizada, afirmou: "Sérgio, me entrevista! Eu tenho coisas pra falar sobre a minha qualidade de vida aqui, porque eu sou uma das que está com a corda no pescoço. Sou da Turma ..." (Sandra).

Foi possível, durante o cotidiano, percebermos que a chamada Turma de Irregulares é uma questão institucional, uma "demanda" dos trabalhadores em geral e não somente dos pertencentes a este grupo.

Devido a este tema insurgente no dia-a-dia, uma conversa foi marcada com Silva, técnico administrativo em situação irregular, alocado na Tec e participante da "Comissão da Turma de Irregulares"28".

Segundo Silva, em outubro de 2007, a "Rádio Peão" começou a falar sobre uma suposta irregularidade no contrato dos trabalhadores que entraram depois 1988. Atualmente, sabe-se que o Ministério Público vinha acionando judicialmente a ESB havia 8 anos, mas somente nesta data a ESB havia perdido em última instância na justiça e "a coisa havia pegado fogo" (Silva). Silva afirmou que após uns três meses a ESB se pronunciou oficialmente, enviando um e-mail a todos os funcionários no qual dizia que o Ministério Público havia julgado os contratos de trabalho dos 973 funcionários admitidos logo após 1988 como "contratos nulos" (Silva). Em 1988, com a Constituição Brasileira, qualquer admissão para uma Empresa Pública devia ocorrer mediante concurso público, porém a ESB desrespeitou tal Lei. Silva afirmou que a ESB tinha uma autorização do Governador do Estado, na época, para contratar sem concurso, mas os promotores estariam "querendo mostrar serviço e sendo

\footnotetext{
${ }^{28}$ Comissão formada por trabalhadores das diversas áreas e cidades que possuem funcionários nesta situação.

${ }^{29}$ Rádio Peão é o apelido ao movimento de burburinho que corre pelos trabalhadores da ESB acerca de informações não-oficiais sobre os diferentes assuntos institucionais, como, por exemplo, suposta troca de Diretor de alguma área, algum concurso sendo preparado para um futuro breve etc.
} 
extremamente legalistas, jogando a Constituição em cima da mesa e fim de papo" (Silva).

Este trabalhador comentou que, no início, foi terrível, pois parecia que haviam sido atacados, acertados por um golpe. Atualmente ele afirma estar menos angustiado, "talvez aceitando o pior". Afirmou que não conseguia dormir no início dos boatos e que agora se sente pisando em ovos, como se a qualquer instante tudo pudesse ruir.

Comentou:

"É... isso tem a ver com qualidade de vida, aqui no trabalho. Eu não tenho motivação pra vir trabalhar mais não. Sei que (...) tudo isto se deve a todos, mas sei também que, por mais ínfima que seja, eu tenho responsabilidade por isto aqui. Eu contribuí com uma fração, por mais ínfima que seja. Agora parece que estou aqui trabalhando, mas não faço mais parte disso tudo. Meu nome, na relação de funcionários, nem devia estar lá..."

Os trabalhadores chegaram a acionar o Sindicato, porém, com medo da entidade sindical demorar a agir, elegeram uma Comissão e agendaram uma reunião com o Presidente. Segundo Silva, o Presidente comentou que não pretendia assinar o PAC - Programa de Ajustamento de Conduta, proposta na qual a ESB se comprometeria a demitir todos os funcionários irregulares, fato que acalmou o grupo.

Para Silva, a qualidade de vida atualmente em seu trabalho é péssima, pois não sabe sequer se terá um trabalho no dia seguinte.

Quando questionado sobre o quanto ele considerava que os responsáveis pelo Programa de Qualidade de Vida poderiam fazer alguma coisa para este grupo, Silva foi desanimador. Primeiro, comentou que nada podia ser feito. Após parar alguns instantes para pensar, comentou que talvez fosse interessante disponibilizar algum atendimento psicológico "mas só para quem quisesse!". Segundo ele, alguns dos trabalhadores nesta situação têm sofrido muito, pois não pode-se planejar nada para o futuro, não se pode prever se vai ganhar o salário do mês seguinte. Devido ao julgamento do contrato de trabalho destes funcionários como "nulos", eles não teriam direito algum a receber. 
Segundo Rose, conforme comentamos anteriormente, o RH estaria de "mãos atadas" junto a este grupo, pois qualquer ação institucional voltada para estes trabalhadores poderia vir a ser usada contra eles. Neste sentido, uma ação para melhoria da qualidade de vida destes trabalhadores poderia ser vista como uma "ação da ESB que confirma que estes funcionários são diferentes dos outros, como se a ESB aceitasse que estão irregulares" (Rose).

Neste caso, vivenciamos o sofrimento de funcionários (e seus colegas, que em grande maioria se sensibilizam) que não podem ser alvo de qualquer Programa de Qualidade de Vida para os Trabalhadores. Por mais que, segundo Silva, a constituição de um grupo os tenha fortalecido enquanto trabalhadores da ESB, cabe ao RH e seu PQVT ajudá-los justamente negando-lhes a existência enquanto grupo, mediante a não realização de qualquer ação direta. 


\section{6) O Selo Ouro de Combate ao Fumo do PQV}

Um assunto recorrente em nossas visitas à ESB foi o Programa de Combate ao Fumo. Ao comentar sobre a natureza da pesquisa aos trabalhadores, nos corredores da área Tec, era comum algum trabalhador falar: "Programa de Qualidade de Vida? É o negócio do combate ao cigarro, né? Vai falar com algum fumante pra você saber disso.", como disse Jéferson, ou "Você veio pesquisar o PQV? É por causa das brigas que o negócio de não poder fumar está dando?” como Deise afirmou.

Como afirmamos anteriormente, segundo Bete, o novo Presidente da ESB trouxe a proposta de conseguir o Selo Ouro de Combate ao Fumo para a ESB e decretou, inicialmente, a proibição do fumo dentro das áreas fechadas da empresa, decretando posteriormente a proibição do fumo dentro de qualquer área da ESB.

A ESB possui instalações muito amplas, como quarteirões inteiros contando apenas com alguns prédios e amplos estacionamentos, fazendo com que alguém que queira fumar tenha que se deslocar, às vezes, centenas de metros para alcançar a portaria e fumar "na rua", como dizem os funcionários.

Marta, trabalhadora da ESB há mais de vinte anos, é uma das mais revoltadas com a situação. Esta funcionária foi, inclusive, indicada por colegas como uma "boa sugestão de pessoa a ser entrevistada". Ao conversarmos com esta funcionária, Marta, de imediato, pediu: "Eu quero que depois disso tudo que você fizer aqui, depois de conversar com o pessoal, você vá falar com o Presidente, ou escreva uma carta, sei lá, falando desse absurdo!".

Segundo Marta, o Selo Ouro de Combate ao Fumo é chamado pelos trabalhadores de "medalhinha", e continua: "devia ser uma medalhinha mesmo, pra ele colocar no peito!" Ela considera que este tipo de medida não pode ser tomada autoritariamente, que o Programa de Qualidade de Vida é feito pra melhorar a vida das pessoas, e não pra "ferrar com a gente". Continua: "Como é que o cara baixa isso na cabeça da gente, que negócio de qualidade de vida é esse que a gente tem que engolir, é obrigado, tem que ficar se escondendo, como se estivesse fazendo uma coisa errada? Isso está errado." (Marta).

Aqui retomamos a idéia da indissociabilidade entre forma e conteúdo, expressa na frase de Derrida: "a moldura faz parte do quadro": o "conteúdo" da proposta 
contra o fumo vai ao encontro de diversos estudos sobre a promoção de qualidade de vida, porém, a moldura desta iniciativa corporativa é compreendida pelos trabalhadores como um "decreto autoritário" do presidente da instituição, "moldura" essa que atua em sentido contrário, pois atinge os trabalhadores em sua autonomia no local de trabalho.

Bete, ao comentar sobre o Programa de Qualidade de Vida, falou sobre a proibição do fumo nas instalações da ESB, mas não aludiu diretamente sobre a indignação dos trabalhadores em geral sobre o fato. Jéferson, que não é fumante, se colocou contra a medida, afirmando:

"Eu não fumo, mas não acho que o pessoal que fuma tenha que ir pra rua pra fumar. Aqui fora dos prédios é tudo aberto, pra que esse negócio? O pessoal não tem tempo pra andar tanto, então teve vez que estavam fumando embaixo duma árvore ali atrás, mas depois começaram a falar e foram fumar nos banheiros... Devia ter alguma consulta". (Jéferson)

Marta comentou que considera uma grande intromissão na vida particular do funcionário uma medida como essa, e considera que a empresa não pode ir adentrando tal individualidade das pessoas. "Acho muito legal fazer folheto informativo, deixar grupo pra quem quer, indicação de tratamento pra quem quer... Mas o remédio, que é caro, isso eles não dão, né?"

Para Marta, é extremamente desagradável dirigir-se à frente da portaria, "na rua", para fumar. Segundo ela, este é um sentimento comum aos fumantes, que costumeiramente criticam a exposição pessoal e até mesmo um sentimento de vergonha. Marta afirmou:

"Tem gente ali que fica com vergonha, pois do jeito que está, a gente fica ali na frente porque é 'fraco', porque não consegue parar, mas na verdade, a gente não quer parar de fumar. A vida é nossa, eu gosto de fumar, não to ali porque não consegui largar, estou ali fumando porque eu gosto de fumar, poxa!" (Marta).

Esta funcionária tentou, em vão, mobilizar os fumantes que se encontram na frente da empresa para fumar, para que fumassem sempre nas mesmas horas de forma a gerar um aglomerado de pessoas que chamasse a atenção dos pedestres e até 
mesmo da imprensa. Porém, ela afirmou que isto não deu certo porque muitos ficaram com medo de represália e, como boa parte dos fumantes permanece fumando escondido dentro das instalações da empresa, o número de fumantes pareceria menor do que realmente é, coisa que poderia dar uma falsa impressão de sucesso do programa anti-tabaco.

Deetz (1992) comenta que uma exposição clara dos mecanismos de poder no ambiente de trabalho, vislumbrados pela demonstração de hierarquia e submissão, indica muito mais a falência dos mecanismos disciplinares do exercício dos poderes do que exatamente a estrutura de poder: só se percebe a assimetria do poder quando toda a estrutura de micropoderes disciplinares não deram êxito. A idéia de Marta caminhava neste sentido, ao buscar explicitar a "submissão" daqueles fumantes ao lado de fora da empresa.

Marta resiste à internalização da disciplina e, de forma muito clara e consciente, mantém a instância repressora externa à sua existência: ela fuma fora da empresa somente pelo fato de que a proibiram de fumar dentro dela, mas não assume para si o estilo de vida e comportamento disseminados pelo programa de qualidade de vida.

Marta vai além e profere um contra-discurso, situando-se "fora" do discurso de Qualidade de Vida da empresa, ao afirmar que fuma porque gosta e não porque "não consegue parar". Na fala dela, ela se constitui enquanto sujeito autônomo e consciente, ao invés de um sujeito viciado e envergonhado oferecido pelo discurso institucional.

O fumo em lugares escondidos dentro da empresa, em momentos que tornem susceptível tal ato, nos remete ao conceito de tática, presente em Certeau (1997). A tática, enquanto "arte do fraco", "não tem por lugar senão o outro (...) a tática é movimento 'dentro do campo de visão do inimigo' " (p. 97). Por não possuir um lugar próprio para agir, a tática permite escapar ao poder, sem entretanto deixá-lo, como ocorre ao funcionário que fuma escondido no banheiro, por alguns minutos.

Porém, a contribuição de Certeau continua: Marta, ao buscar combinar com os fumantes um movimento de aglomeração à frente da entrada da empresa, desafiava a pressão do "estilo de vida saudável" imposto pela empresa, aceitando o lugar que fora deixado aos fumantes: a área em volta da porta de entrada. Neste sentido, Marta, ao 
aceitar o "lugar", pretendia ocupá-lo de forma a utilizá-lo contra a empresa, como no exemplo de gerar um transtorno na entrada da instituição a ponto de ser interessante para a imprensa noticiar o fato. Nesta circunstância, podemos dizer que Marta tentou sair do campo da tática para a dimensão da estratégia (Certeau, 1997), que, diferentemente da situação anterior, possui um lugar a ser ocupado e lançar-se à ação.

Marta, ao aprofundar as críticas a esta Ação institucional do Programa de Qualidade de Vida dos Trabalhadores da ESB, foi enfática: "Eu juro que ainda vou conversar com um advogado! Se couber uma ação, eu vou entrar! Isso é coerção! É assédio moral. Não podem querer me fazer parar de fumar me deixando com vergonha".

Segundo esta funcionária, não são somente os fumantes que estariam sob ação de "assédio moral" (Marta), mas esta seria uma prática constante do novo Presidente da ESB. Marta comentou:

\footnotetext{
"Você sabe da campainha, né? O Presidente fica no prédio central aqui dessa unidade. Teve um dia que tocou um alarme no prédio central e a gente achou que era da brigada de incêndio, pra você ter uma idéia! Sabe o que era? Era uma campainha que o Presidente aperta na mesa dele e soa em todo canto, que nem escola pra mandar a criançada ir pra classe, é o Presidente mandando os Diretores pra sala dele! Diretores, que podem estar em reunião com não-seiquem! Diretores, que estão na empresa de 25 anos pra mais, e não há um ano, que nem esse indicado por político" (Marta).
}

Este exemplo questiona a racionalidade por trás do Programa de Qualidade de Vida para os Trabalhadores, apresentado no bojo de uma série de medidas administrativas muitas vezes incoerentes entre si. Neste caso específico, fomos convidados pela funcionária a estar nas dependências da empresa no dia da próxima reunião do Presidente com os Diretores. Marta: "Vem ver, fica ali sentado no meio jardim, que ele gastou um monte de grana pra encher de flor pra melhorar o ambiente, escutar o som da campainha pra criança!" (Marta). 


\section{7) O “Chão de Fábrica”: terceirização e precarização.}

Durante uma entrevista com Marcílio, Engenheiro de Segurança encarregado da Tec, na qual foram explicitados alguns cuidados relativos à prevenção de acidentes nas áreas administrativas, nos foi sugerido que abordássemos os chamados "macacões-azul", ou seja, os trabalhadores que atuam no "chão da fábrica" da ESB. Segundo o engenheiro, as funções das áreas administrativas e das áreas industriais são tão diversas que seria interessante, para se conhecer qual a "verdadeira Qualidade de Vida na ESB" (Marcílio), um contato direto com os trabalhadores operacionais.

Esta não foi a primeira vez que estes trabalhadores foram "sugeridos" ao pesquisador. Marta, em uma conversa, explicitou que "a verdadeira ESB são os que vestem macacão-azul, vá ver se eles sabem o que é Programa de Qualidade de Vida".

A sugestão de se pesquisar este grupo, vinda do próprio campo, surge tal como uma categoria social (Rockwell, 1987) e mostra quão relevante foi a proposta metodológica negociada junto ao campo.

Após estas sugestões, conversamos com Cláudia, uma engenheira de segurança encarregada por trabalhadores operacionais terceirizados. A terceirização é um fenômeno recente na ESB, ocorrendo pela primeira vez pouco antes da abertura de capital da empresa.

Segundo Antunes (2007):

\footnotetext{
"pode-se constatar uma nítida ampliação de modalidades de trabalho mais desregulamentadas, distantes da legislação trabalhista, gerando uma massa de trabalhadores que passam da condição de assalariados com carteira para trabalhadores sem carteira assinada. Se nos anos 1980 era relativamente pequeno o número de empresas de terceirização, locadoras de força de trabalho de perfil temporário, nas décadas seguintes esse número aumentou significativamente, para atender à grande demanda por trabalhadores temporários, sem vínculo empregatício, sem registro formalizado. Ou seja, em plena era da informatização do trabalho, do mundo maquinal e digital, estamos conhecendo a época da informalização do trabalho, dos terceirizados, precarizados, subcontratados, flexibilizados, trabalhadores em tempo parcial, do cyberproletariado, conforme a sugestiva indicação de Ursula Huws (2003). Não é por acaso que a Manpower é símbolo de emprego nos EUA." (Antunes, 2007, p.25).
} 
A terceirização é sinônimo de precarização do trabalho, segundo Antunes (2007) e Hirata (2007). Os terceirizados não possuem vínculo empregatício com a empresa na qual estão lotados e se vêem em meio a diversos trabalhadores do mesmo cotidiano que possuem benefícios e direitos que lhes são negados. Na ESB, a situação dos terceirizados é a mesma descrita pelos autores citados.

A primeira questão que nos chamou atenção é o fato dos trabalhadores da ESB remeterem aos terceirizados como uma fonte interessante para a pesquisa. Algumas falas demonstravam certa indignação com a situação dos terceirizados, e indicavam uma identificação enquanto classe pelos trabalhadores da área Tec junto aos demais trabalhadores terceirizados. Silva chegou a comentar, dentro de uma conversa à respeito das diferentes apropriações do PQV pelos diferentes ambientes da empresa: “Esse programa de qualidade de vida não é pra todos nós não, porque os que são de terceirizadas não entram" (Silva). Na fala de Silva, os trabalhadores terceirizados entram na categoria "nós". As sugestões em se pesquisar os terceirizados tinham, algumas vezes, fundamento em promover uma "denúncia" da situação destes.

Após contatarmos Cláudia, uma conversa foi agendada. Cláudia, funcionária "registrada" da ESB, comentou sobre as diferenças a respeito do contrato dos trabalhadores terceirizados. Afirmou que a quantia paga para a empresa terceirizadora por cada empregado é, muitas vezes, maior que o dobro daquilo que o trabalhador recebe. Cláudia exemplificou falando que, se pagam cerca de dois mil reais para cada funcionário terceirizado, é comum ver o trabalhador receber oitocentos reais de salário e também encontrá-los reclamando de vale-refeição atrasado.

Foi comentado que muitas vezes um funcionário é demitido por alguma empresa terceirizadora (não exatamente a empresa contratada pela ESB, mas algo que, segundo a engenheira, não é incomum no "mundo das empresas terceirizadoras"), mas esta empresa não entrega ao funcionário a rescisão do contrato, o papel que lhe informa a decisão, o que faz com que a empresa continue a receber o salário da pessoa e, após 2 meses, este funcionário é demitido "oficialmente" por "justa causa" mediante abandono do emprego, sendo demitido sem receber o que teria direito.

O que permite tal abuso, segundo Cláudia, é a falta de conhecimento dos trabalhadores terceirizados, que, em sua maioria, são pessoas oriundas do trabalho 
agrário e sem experiência com relações trabalhistas, possibilitando serem "passadas para trás" (Cláudia) pelas empresas. Cláudia afirmou que um elemento muito importante para a existência destas empresas terceirizadas é a abundância de mão de obra e o fato das empresas não quererem se responsabilizar pelos trabalhadores, evitando estabelecerem relações trabalhistas.

Acerca da abrangência do Programa de Qualidade de Vida Viver Feliz a estes trabalhadores que prestam serviço somente à ESB, muitas vezes há anos no mesmo ambiente, lado a lado com trabalhadores "registrados" da empresa, Cláudia afirmou: “Não... Qualidade de Vida é preocupação pros funcionários que vão ficar aí pra sempre [referindo-se aos funcionários públicos, contratados por concurso, estatutários etc.]" (Cláudia). Quando questionada acerca de como as empresas terceirizadas reagem frente à deterioração da vida de seus trabalhadores, acidentes ou problemas devido à penosidade e insalubridade do trabalho daqueles, Cláudia afirmou: "Estas empresas mandam embora e contratam outros. Em terceirizada, é como se o trabalhador fosse descartável."

Cláudia, durante toda a conversa, colocou-se de forma crítica à política da ESB em contratar empresas terceirizadoras. Para ela, como para os trabalhadores da área Tec, seria melhor que todos tivessem os mesmos direitos, já que trabalham na mesma empresa.

Porém, quando perguntamos se poderíamos conversar com algum trabalhador da terceirizada, Cláudia respondeu que não se sentia confortável em intermediar tal conversa, pois o próprio trabalhador poderia ser prejudicado, caso algum supervisor visse "um terceirizado dando entrevista" (Cláudia).

Ao negar acesso aos trabalhadores terceirizados, negou-se concomitantemente que o discurso destes sujeitos tenha lugar. Por mais que se posicione pessoalmente de forma crítica à política de terceirização, esta engenheira de segurança percebe que o discurso destes trabalhadores precisa manter-se interdito.

Os trabalhadores diretos da ESB, ao contrário dos terceirizados, puderam conversar com um pesquisador. A diferença entre estes grupos, no tocante ao exercício do poder, está no fato de que aos terceirizados cabe o controle externo e violento, enquanto que os funcionários da ESB são alvos de programas internos de internalização da disciplina para que venham a "vestir a camisa da empresa". Neste 
sentido, talvez se espere que um funcionário direto possua seu discurso disciplinado, e por isso mesmo não tão perigoso, enquanto que o trabalhador terceirizado, por não ser alvo de qualquer programa institucional, tenha seu discurso como sendo ameaçador ou denunciador, culminando em sua interdição.

Tal como afirma Lebrun (1984), Foucault narra um sofisticado mecanismo disciplinar que, no Brasil, nem todos os espaços precisaram utilizar, justamente devido à precariedade das relações. Para estes casos, diferentemente do poder disciplinar Foucault (1997), cabe o poder externo, violento e assimétrico ${ }^{30}$.

\footnotetext{
${ }^{30}$ Refletiremos detalhadamente sobre a pertinência do poder disciplinar (Foucault, 1997) para algumas dimensões das organizações de trabalho no Brasil, mas não à todas, no próximo capítulo.
} 
Capítulo 9: A multiplicidade de modalidades de exercício do poder na realidade brasileira. 
O tema do Poder, mesmo presente de forma mais ou menos indireta nas primeiras obras de Foucault, toma um novo corpo após Vigiar e Punir, de 1975, e A Vontade de Saber, de 1976, primeiro volume da trilogia História da Sexualidade.

Segundo Roberto Machado, organizador das aulas e entrevistas que no Brasil compõem o livro Microfísica do Poder (1979), e elaborador da introdução do livro, Foucault utilizava o método arqueológico para estudar a constituição dos saberes, como estes se relacionavam entre si e como se articulavam com as instituições. Após este primeiro momento de análise, a questão do poder apareceu como um meio de se estudar como surgiam saberes, ou seja, por que tal saber aparece como um campo do conhecimento em determinado momento e quais fatores externos culminaram na produção desta nova área do saber, sendo este sempre um surgimento "estratégico". Em suma, a quem interessa que este saber venha a existir? 0 saber passa a ser considerado como uma peça nas relações de poder.

Nesta proposta, não existiria uma teoria geral do poder em Foucault, o poder não seria um objeto natural, uma coisa, mas sim uma prática social e, como tal, constituída historicamente (Machado, 1979, p.X).

Após estudos sobre a formação histórica das sociedades capitalistas, instituições carcerárias e a constituição do dispositivo da sexualidade, Foucault teria vislumbrado algo que ia na contra-mão de um certo senso comum político, a não sinonímia entre Estado e poder. Esta análise não é nova, estava presente desde Hegel (Lebrun, 1984), mas assume agora em Foucault um interesse nas ramificações que uma mudança estatal produzia ao ir permeando instituições, práticas cotidianas e corpos sociais. Por isto, este poder último poderia ser caracterizado como micropoder. A microfísica do poder focalizaria como estas alterações viriam a constituir-se 
em "técnicas de poder que realizam um controle detalhado, minucioso do corpo gestos, atitudes, comportamentos, hábitos, discursos" (Machado, 1979, p. XII.).

É importante nesse novo momento das pesquisas de Foucault que os mecanismos de poder aparecem, oriundos do campo, como claramente não subordinados a um poder central. Uma coisa seria o poder estatal com suas especificidades, outra, com especificidades diferentes e próprias, seriam os mecanismos de poder que se apresentavam dentro de um hospital, prisão ou empresa, por exemplo. A análise minuciosa do campo permitia o surgimento de verdadeiros micro-cosmos.

Apesar da Revolução Francesa ter influenciado toda uma gama de saberes e seus poderes específicos, como a ciência, a medicina etc, isso não era uma regra. Uma conseqüência muito importante deste enfoque é que não bastaria o controle do Estado ou sua destruição para que toda uma gama de mudanças viesse a ocorrer, como um efeito dominó. A instauração do socialismo, por exemplo, não garante que prisões ou mesmo conventos sofressem uma revolução nos seus mecanismos internos. Esta ótica é central para entendermos de onde partem muitas críticas a Foucault, como a dos marxistas ortodoxos.

Nesta análise, os poderes não estariam localizados em nenhum ponto da estrutura social, não possuiriam fronteiras e atingiriam a todos. Daí a polêmica idéia que o poder não é uma coisa a ser possuída, não existindo de um lado os que detêm o poder e de outro os que dele são alijados. "Rigorosamente falando, o poder não existe; existem sim práticas ou relações de poder. O que significa dizer que o poder é algo que se exerce, que se efetua, que funciona" (Machado, 1979, p. XIV). Onde há poder, há também resistência, o que consecutivamente implica que não exista também um lugar da resistência, mas sim pontos móveis e transitórios que se distribuem por toda a estrutura social. Dessa forma, Foucault rejeita a idéia trazida pelo modelo econômico, onde o poder seria tal qual uma mercadoria.

Outra importante conseqüência desta teoria molecular do poder seria que explicá-lo somente pelo seu fator repressivo é insuficiente, pois, mais que limitar, a prática do poder objetiva disciplinar. Seriam "métodos que permitem o controle minucioso das operações do corpo, que asseguram a sujeição constante de suas forças e Ihes impõe uma relação de docilidade-utilidade(...)" (Foucault, 1977, p. 127). Este 
seria o esquema de um poder que não atua no exterior, mas no interior dos corpos, produzindo comportamentos e conseqüentemente o tipo de sujeito necessário ao funcionamento e manutenção da sociedade industrial, capitalista.

Os eventos e Programas de Qualidade de Vida aos Trabalhadores pesquisados se inserem nesta modalidade positiva de exercício de poder: buscam imprimir no trabalhador todo um estilo de vida e de hábitos supostamente saudáveis. Aqui, saudável pode ser também interpretado como útil para a organização: a respiração ayur-védica descrita no capítulo 6 é tão "saudável" quanto o hábito de se pedir um "lanche saudável" na própria mesa de trabalho para não sair para almoçar, como descrito no capítulo 7. É neste sentido que o contrário de saudável é apreendido pela organização quando algo acontece de forma a afetar o desempenho do trabalhador, conforme explicitado pela gestora de RH da ESB.

A disciplina, em primeiro lugar, é um tipo de organização no espaço. Atua pela distribuição dos indivíduos através da inserção dos corpos em um espaço individualizado, classificatório e combinatório. Ela é também um controle do tempo, obrigando o corpo a render-se ao tempo, com o objetivo de produzir o máximo de rapidez e o máximo de eficácia. Um dos principais mecanismos de controle para a efetivação da disciplina é a vigilância. Quanto mais a vigilância for sentida como contínua e abrangente, maior sua eficácia. Principalmente, a vigilância produz um registro da realidade. É justamente aqui onde o poder gera um saber. O olhar, que observa para controlar, anota e registra para irrigar de saber os postos mais altos na hierarquia de poder. Novos saberes são criados a partir de "relatórios" de enfermeiros, carcereiros, avaliações organizacionais de desempenho e etc.

Esta nova perspectiva passa a encarar o poder em sua característica positiva. 0 poder gera positividade, se caracteriza mais por criar e gerir do que por limitar e oprimir. O poder capitalista, neste sentido, muitas vezes associado à idéia de massificação e despersonalização, passa a ser encarado por Foucault como o criador do indivíduo moderno, e não como seu diluidor. Criador dos hábitos, costumes, prazeres e desejos daquilo que vem a caracterizar o indivíduo.

As técnicas disciplinares, que são também técnicas de individualização, teriam criado então um tipo específico de saber: as ciências humanas. Foucault tem como 
orientação buscar situar a origem das ciências humanas fora do campo de produção e da estrutura econômica, mas sim a partir de práticas políticas disciplinares.

Algo muito importante sobre a análise proposta por Foucault é não fazer-se diferença entre ciência e ideologia. Para Foucault, mais importante que saber se algo é ou não verdade, é saber como aquilo veio a ser verdade. Esta perspectiva de caminhar entre os discursos instituídos, sem bater de frente com nenhum deles, é o que garante a Foucault um lugar entre os autores considerados pós-modernos.

Gérard Lebrun ${ }^{31}$, em O Que é Poder (1984), toma um caminho diferente para trabalhar o tema do poder e tece uma crítica à noção foucaultiana. Para Lebrun, poder é uma aplicação específica de Potência. Ele cita o conceito de Max Weber: "Potência (Match) significa toda oportunidade de impor sua própria vontade, no interior de uma relação social, até mesmo contra resistências, pouco importando em que repouse tal oportunidade". O poder existe quando uma potência se explicita de uma maneira muito precisa, que é quando se faz dirigida a alguém que tem que obedecê-la. Lebrun assinala o caráter dissimétrico, não igualitário que caracteriza o exercer poder.

Segundo Lebrun, antes de Foucault, muitos outros buscaram dissolver o poder, tratando-o fora dos padrões que envolvessem a coerção propriamente dita. 0 sociólogo americano Talcott Parsons, ao preferir o termo Controle Imperativo ao invés de Dominação, teria privilegiado intencionalmente relações de poder à coerção, porém, devido a isso, Parsons não pode ser utilizado como um teórico que consiga dar conta de formas diferentes de governo que a democracia ocidental. Hegel também teria "amenizado" o elemento de dominação do poder.

Para Lebrun, inicialmente, teóricos que seguem a linha de Parsons focalizam quase unicamente as democracias ocidentais, democracias estas que, quando consideradas sob a seriedade das eleições dos países em particular, tornam-se minoria no conjunto internacional. E mais, mesmo dentro destas democracias, a concessão de poder ao governante se faz de forma concreta. Quando se deixa de cumprir algum dever, sofre-se sanções, multa ou mesmo prisão. Troca-se liberdade por segurança.

Para Parsons, a submissão ao poder se dá pela simples aceitação da autoridade, ao invés do medo pela punição. Neste livro, escrito originalmente em 1981, Lebrun

\footnotetext{
${ }^{31}$ Falecido professor do Departamento de Filosofia da USP, de origem francesa, veio como professor visitante da Sorbonne em 1960 e alternou aulas em cada universidade, até sua morte em 1999.
} 
comenta com sarcasmo: "Não sei como Parsons ou os seus discípulos explicariam o que aconteceu em Nova lorque durante o célebre corte de energia elétrica - mas é fato que a certeza da impunidade mostra logo como é frágil o respeito pela autoridade" (Lebrun, 1984, p.17).

Parsons, como Foucault, rejeita a idéia que o poder é "mercadoria rara", ou seja, que o poder que alguém possui existe em contrapartida do poder que alguém não possui. Se alguma pessoa tem poder, deve haver uma ou mais pessoas desprovidas de poder. Segundo Lebrun, é o que a sociologia norte-americana chama de "Teoria Soma-zero do Poder". Diferentes autores apresentariam noções semelhantes de poder, como Marx, Nietzsche, Max Weber, Raymond Aron e outros. Mesmo divergindo sobre fatores ligados, como se o poder se agrava ou não numa sociedade de classes, o importante é que estes autores partem da premissa que o poder é um quantum definido, estável, de "soma zero".

Em A Vontade de Saber, Foucault rejeita a teoria da soma zero, com argumentos diferentes das de Parsons. Retomemos três dos seus argumentos principais: o poder não deve ser encarado pelo viés interditor, mas sim pelo seu caractere organizador e criador; o poder é mais instaurador de normas que de leis; deixemos de encarar o poder como estranho ao indivíduo, mas dele constituinte.

Lebrun comenta que Foucault é apressado em subestimar a matriz “ordem/obediência" do poder. Quando a questão é tentar entender por que tantos se dobram cegamente à dominação, talvez fosse necessário primeiro levar em consideração a situação de enormes quantidades de pessoas que simplesmente sempre foram destituídas de poder, pessoas cujo ato de questionar o estabelecido pareça irracional, tal como questionar um fenômeno da natureza.

\footnotetext{
"Ainda que o poder não seja uma coisa, ele torna-se uma, pois é assim que a maioria dos homens o representa. É preciso situar a tese de Foucault dentro dos seus devidos limites: o homem condicionado, adestrado pelos poderes, é o privilegiado, o europeu. Não é o colonizado, não é o proletário do terceiro mundo (...). Estes, o poder não pensa sequer em domesticar: domina-os - e muito de cima." (Lebrun, 1984, p. 21).
} 
O conceito de poder de Foucault claramente amplia o leque de ferramentas conceituais para se trabalhar fenômenos sociais. Traz como destaque, inclusive, o fato de ter sido um aparato conceitual sugerido pelo campo, "puxado" pelas pesquisas empíricas e documentais que o autor promovia.

A noção de poder disciplinar permitiu, por sua vez, novos olhares frente instituições, possibilitando ao pesquisador esquadrinhar e seguir as influências gerenciais e cotidianas até "níveis moleculares", o corpo mesmo dos sujeitos, seus hábitos e comportamentos.

Tão importante quanto a afirmativa de Foucault sobre as especificidades das instituições, seu cotidiano e micro-cosmos, é reconhecer também sua autonomia com relação aos estilos de fazer "o poder" presente em seu cotidiano. Neste sentido é muito interessante a análise feita por Gerard Lebrun mais de 20 anos depois de conhecer o Brasil. Lebrun situa o quanto a análise foucaultiana é pertinente ao ambiente europeu e o quanto ela aparece não dando conta da totalidade do cenário brasileiro.

Aqui cabe citar Sartre (1973), quando diz que existem diferentes temporalidades atuando num mesmo cotidiano. Buscar compreender o cotidiano é tentar entender como diferentes práticas foram se assentando, sobrevivendo e mantendo atividades referentes a épocas distintas. Em todas as situações, e principalmente em lugares como o Brasil, onde a contradição é explícita, podemos encontrar práticas que nos possibilitem uma referência na teoria da "soma zero" de poder, clássica da sociologia, e também podemos nos deparar com elementos que escapam a esta teoria e são melhor descritos pela teoria do poder disciplinar articulado por Foucault.

Deetz (1992), ao falar sobre o poder disciplinar na corporação moderna, enriquece muito o debate esquadrinhando uma série de influências morais, mecanismos reguladores de ordem médica, sexual e psicológica, que são formas sutis de adestrar o trabalhador, docilizá-lo, como Foucault descreveu. Porém, talvez o "vestir a camisa" da empresa, seus valores e normas, não possa ficar descolado da análise da estrutura econômica como Foucault demonstra evitar. No Brasil, a pressão concreta pela escassez de emprego e o drama do exército da mão de obra batendo à porta de quem possui alguma estabilidade no trabalho promovem uma opressão clara 
sobre o trabalhador. O trabalhador nestas condições não precisa ser adestrado: não irá embora, pois não há para onde ir.

Se, por um lado, percebemos os Programas de Qualidade de Vida aos Trabalhadores enquanto práticas disciplinares que buscam "educar" o trabalhador de ambientes mais administrativos e burocráticos para a (suposta) nova configuração da gestão de pessoas (pós-fordismo, sociedade pós-industrial etc.), por outro lado, precisamos refletir do porque destes Programas de QVT não estarem dispostos aos trabalhadores terceirizados, por exemplo. Nossa tese, portanto, é que estes trabalhadores não precisam ser domesticados, pois a eles não cabe a docilização do mundo administrativo: à eles cabe tão somente a coerção explícita, o olhar constante do supervisor e a ameaça de perder o emprego caso não cumpra as regras.

Se há, nos meios administrativos, a política de "reter talentos", como demonstramos ao explicitar as propostas da Gestão por Competências, Organizações de Aprendizagem e Gestão do Conhecimento, em setores como o das terceirizadoras de serviços operacionais, tal como relataram os trabalhadores da ESB, não existe nada mais além de compra e venda de mão-de-obra que possui rápida substituição devido ao enorme montante de desempregados disponíveis.

Nestas condições, parece que as empresas não buscam introjetar a disciplina fazendo o trabalhador "vestir a camisa", como Deetz afirma, visto que eles são descartáveis e substituíveis. A estes trabalhadores, a contradição pode permanecer explícita e a Teoria Soma-zero do Poder parece mais condizente. 
Capítulo 10: Programas de Qualidade de Vida para os Trabalhadores enquanto prática de Biopoder e Governamentalidade 
Como vimos, no transcurso dos séculos XVII e XVIII, Foucault identificou uma nova mecânica do poder, que viria a substituir a sistemática preconizada pela teoria jurídica de soberania (centrado no Estado) e pela noção clássica marxista que identifica o poder enquanto posse dos meios de produção.

Chamado de poder disciplinar, tal modalidade de poder incide, por meio de práticas de vigilância, diretamente sobre os corpos, extraindo deles tempo e trabalho. Segundo Foucault, este poder disciplinar, desprovido de qualquer centralidade e marca de soberania, "foi um dos instrumentos fundamentais da implantação do capitalismo industrial e do tipo de sociedade que Ihe é correlativo" (Foucault, 2005, p.40).

Desta forma, com base no período que abrange desde o encerramento do Antigo Regime até a primeira fase do capitalismo (industrial), Foucault (2005, p.116) passa a falar em uma "Sociedade Disciplinar ${ }^{32 " . ~ B e l l o ~(2007) ~ c o m e n t a ~ q u e ~ e s t a ~}$ modalidade de organização social, também chamada de "sociedade de vigilância", representou a "idade da ortopedia social" (p.4) e desenvolveu-se com base em instituições disciplinadoras, tais como prisões, hospitais e fábricas, inspiradas no Panopticon de Jeremy Bentham.

Após o desenvolvimento das formulações de poder que articulavam sua multiplicidade, Foucault esboça, em sua última aula do College de France, uma formulação da teoria do poder político calcada na noção de "biopoder", sendo esta vinculada ao tema da governamentalidade e desenvolvida posteriormente em obras e artigos posteriores, como "História da Sexualidade", "A Vontade de Saber",

\footnotetext{
${ }^{32}$ Negri e Hardt (2004) oferecem esclarecedora definição do termo: "Sociedade Disciplinar é aquela na qual o comando social é construído mediante uma rede difusa de dispositivos ou aparelhos que produzem e regulam os costumes, os hábitos e as práticas produtivas"
} 
"Segurança, Território e População", "Nascimento da Biopolítica" e "A Governamentalidade".

Foucault trabalha a noção de biopoder a partir da compreensão histórica da formação e do desenvolvimento do respectivo regime político-jurídico (o Liberalismo), que denota um novo modelo de exercício do poder (o poder sobre a vida), compreendido por meio da "arte de governar" ou "governamentalidade".

O surgimento do biopoder surge amparado pelo fenômeno da "estatização do biológico" (Foucault, 2005) e está ligado diretamente à formação das ciências humanas - psiquiatria, psicanálise, psicologia etc. Desta forma, o biopoder é exercido por uma lógica biopolítica que "mediante os biopoderes localizados, ocupar-se-á da gestão da saúde, da higiene, da alimentação, da sexualidade, da natalidade na medida em que esses sujeitos se tornam, no desenvolvimento do Estado moderno, coisas importantes para o poder" (Negri, 2003, apud Bello, 2007).

Esta nova tecnologia de poder está menos preocupada com o disciplinamento do corpo individual, já moldado pelo trabalho parcelar, que com o controle do corpo social.

Foucault caracteriza o biopoder comparando-o ao poder disciplinar:

"Uma tecnologia de poder que não exclui a primeira, que não exclui a técnica disciplinar, mas que a embute, a integra, a modifica parcialmente e que, sobretudo, vai utilizá-la implantando-se de certo modo nela, e incrustando-se efetivamente graças a essa técnica disciplinar prévia. Essa nova técnica não suprime a técnica disciplinar simplesmente porque é de outro nível, está noutra escala, tem outra superfície de suporte e é auxiliada por instrumentos totalmente diferentes.

Vis-à-vis com o processo de transformação do capital, que caminha para sua fase monopolista (no viés econômico) e imperialista (no viés político), no século $\mathrm{XIX}$, poder disciplinar e biopoder passam a constituir uma unidade, por meio da eclosão da sociedade normalizadora, cujos mecanismos de regulação e correção produzem, avaliam e classificam as anomalias do corpo social, ao mesmo tempo em que as controlam e eliminam" (Foucault, 2005, p. 288-289)

Inicialmente, nas considerações acerca do biopoder, seu locus era a cidade. Segundo Braga e Vlach (2004), ainda que somente muitos anos após a Revolução Industrial os rurícolas deixassem de ser majoritários no contexto da população mundial economicamente ativa, as cidades assistiram a um rápido crescimento à medida que 
se configurou uma nova divisão sócio-territorial do trabalho. Citam Teixeira e Cyrino (2003), afirmando que um processo de urbanização avassaladora se deu de 1750 a 1850 em todas as regiões do mundo industrializado, transformando as cidades em focos de ameaças políticas e sanitárias.

Para Foucault, o biopoder tem como agente máximo o Estado moderno, cuja bioregulamentação volta-se não para o "fazer morrer" (como no poder soberano medieval), mas para o "saber viver" (Braga e Vlach, 2004), encompridando o ciclo produtivo da vida humana coletiva.

Segundo Souza e Gallo (2002, apud Braga e Vlach, 2004), o welfare state é um exemplo paradigmático da sociedade biopolítica. Como se trata de "fazer viver" e, em alguns casos, "deixar morrer", a biopolítica teria feito nascer sistemas de seguridade social, de previdências públicas e privadas, de poupanças.

Apesar de identificada no Estado, novos trabalhos articulam o acirramento do biopoder justamente nesta era caracterizada pelo desmonte do Estado de bem-estar social. Hardt e Negri (2004) articulam a idéia de biopoder com a noção deleuziana de Sociedade de Controle e afirmam que o biopoder e a sociedade de controle são os substratos da nova ordem mundial que eles denominam Império.

Com o contínuo enfraquecimento do Estado e o aumento do poder das organizações, principalmente as multi e trans-nacionais, o poder exercido pelas empresas passa a tomar o lugar das práticas de biopoder antes localizadas no Estado.

As organizações capitalistas, principalmente as grandes corporações ${ }^{33}$ (Bakan, 2008) têm sido concebidas freqüentemente como sistemas políticos, e esta imagem da organização (Morgan, 1986) tem sido uma importante via de análise institucional. Para Deetz (1992), concepções desenvolvidas por esta linha imagética têm sido úteis em descrever processos chave de poder e conflito e, segundo o autor, provavelmente se tornarão mais importantes quanto mais completamente compreendidos forem os impactos sociais das grandes unidades corporativas.

Pensar a organização enquanto política é frutífero para compreendermos como novos valores, novas formas de conhecimento e interesses grupais são articulados,

\footnotetext{
33 Joel Bakan, em seu livro A Corporação (2008), descreve, em detalhes dezenas de casos onde as grandes corporações privadas injetaram dinheiro, mediante lobby, no congresso americano e gerenciaram inúmeras decisões da esfera pública, principalmente regulamentações sociais e trabalhistas.
} 
porém, Deetz é enfático ao afirmar que a concepção política da organização é mais que uma metáfora chamativa:

"Corporate organizations serve as a polity. In modern societies they make most public decisions on the use of resources, the development of technologies, the products available and the working relations among people. In many countries the corporate sector makes more public decisions than its governmental counterparts $^{34 \prime \prime}$ (Deetz, 1992, p. 21)

As concepções das organizações enquanto estruturas políticas costumam minimizar sua importância remetendo-se apenas a interesses pessoais e estratégias internas. Segundo Deetz, a corporação é subestimada como um importante lugar de decisões de políticas públicas. Para este autor, ao compreender-se as corporações enquanto entidades políticas numa sociedade democrática, faz-se imprescindível a elaboração de estudos que investiguem a significância do exercício de poder e controle dentro das organizações, ao invés de estudos apenas comprometidos com a operacionalidade e desenvolvimento do controle gerencial.

A noção de biopoder foucaultiana, após a fragmentação contínua do poder do Estado, passa a ser exercida pelas empresas privadas que vêm assumindo o papel daquele.

A empresa total pode ser assim denominada, pois assume a totalidade das responsabilidades sobre seus funcionários, mas não visando suprir necessidades, mas para gerenciar a formação e manutenção de mão-de-obra e de consumidores ao mesmo tempo. É "total" pois amplia seu lastro de poder para além dos muros da instituição, preocupando-se com a gestão de elementos de diversas ordens e penetrando intimamente na vida do trabalhador.

As novas modalidades de gestão de pessoas ampliaram o interesse da empresa para além do período disposto ao trabalho. As atividades físicas dos trabalhadores importam-lhe, pois algumas práticas fazem um funcionário render mais lucro que outras, logo, a criação de quadras esportivas e o patrocínio de competições busca

\footnotetext{
${ }^{34}$ As corporações atuam tal como uma entidade política. Nas sociedades modernas elas tomam mais decisões sobre a utilização dos recursos públicos, desenvolvimento de tecnologias, disponibilidade de produtos e relações de trabalho entre as pessoas. Em muitos países, o setor corporativo toma mais decisões sobre o setor público do que suas contrapartes governamentais.
} 
disciplinar os trabalhadores acerca de quais esportes devem ser desenvolvidos. A gestão por competências, mediante instrumentos de seleção e, principalmente, de avaliação de desempenho, ao valorizar e pontuar alguns conhecimentos em detrimento de outros, restringe o uso do tempo livre do trabalhador a um eterno "qualificar-se", sempre tendo em vista a "competência essencial" da empresa. As empresas que aprendem, ao anunciarem o "fim do trabalho mecanizado" do trabalhador e argüirem que agora é o tempo de trazer a criatividade de volta ao trabalho, não fazem mais que, ao perceberem a impossível prescrição total do trabalho, buscar formalizar o trabalho real visando se apropriarem do conhecimento que era, nas ranhuras do sistema, o próprio exercício de liberdade e criatividade no momento da execução.

Quando Tereza, a consultora entrevistada, descreveu o Programa de Qualidade de Vida da empresa em que trabalhava como um "monstro de mil tentáculos", cuja demissão do emprego fazia os trabalhadores não terem mais referências até de questões fora da dimensão organizacional, como amigos, cabeleireiro ou colegas para praticar algum esporte, estamos frente a um Programa que, ao excluir o trabalhador de seus "tentáculos", fazia-o sentir-se estrangeiro em sua própria terra.

É na descrição de um trabalhador ao dizer que, ao perder o emprego, havia perdido "tudo", que temos a empresa não somente enquanto Estado, mas enquanto um Estado de características fascistas.

Neste caso, a diferença entre estado autoritário e estado fascista faz-se necessária: ao contrário do estado autoritário, o estado fascista possui penetração total de suas ideologias norteadoras, fazendo seus "administrados" literalmente "vestirem sua camisa".

O Programa de Qualidade de Vida para os Trabalhadores da ESB, como pudemos verificar, incide sobre diversas ordens que não a do trabalho propriamente dito: prescreve dispositivos direcionados ao lazer, atividades físicas, atividades culturais, conservação do meio ambiente, saúde etc. Estas ações, chegando ao nível de incumbir-se até da responsabilidade de "conscientizar os trabalhadores sobre doações", busca não somente criar "trabalhadores sadios", mas um tipo característico de "cidadão sadio". Nesta concepção, cabe ressaltar que "sadio" é o adaptado, 
correto, valorado enquanto "bom e útil" tal como se estas características existissem por si mesmas, sem, entretanto, especificarem "a quem interessa esta utilidade".

Inseridos no contexto da governamentalidade (Foucault, 2005), os Programas de Qualidade de Vida para os Trabalhadores emergem enquanto dispositivos de poder cujo contexto abrange mais que a esfera de exploração do trabalho. Não é à toa que algumas iniciativas organizacionais relacionadas ao tema gerem prejuízo financeiro quando analisadas em sua configuração estrita, porém, ao darmos alguns "passos para trás", vemos que a docilização dos sujeitos rende muito mais a longo prazo.

Genealogicamente, mais importante que nos determos na questão "O programa de QV para os Trabalhadores traz benefícios imediatos ou não?" é tentarmos entender como foi possível caber às corporações gerenciar as atividades pessoais de lazer, físicas, sociais e culturais dos trabalhadores.

Segundo Bello (2007), com o aperfeiçoamento da noção de biopoder, já nos últimos momentos da sua produção intelectual, Foucault apresenta de forma implícita uma transição do modelo de sociedade disciplinar para o que recebeu a denominação de "sociedade de controle", concepção que veio a ser atualizada e desenvolvida em novos patamares por Gilles Deleuze em seu livro chamado Foucault, de 1986.

Nestes termos, seria errôneo afirmar que a sociedade de controle estaria plenamente configurada na atualidade, pois, ao contrário, ela ainda está se forjando e em consonância com o processo de superação da "sociedade de vigilância" contextualizada no capitalismo industrial - pelo paradigma de produção do chamado pós-fordismo.

Segundo Hardt \& Negri (2004):

"Devemos entender a sociedade de controle (...) como aquela (que se desenvolve nos limites da modernidade e se abre para a pós-modernidade) na qual mecanismos de comando se tornam cada vez mais 'democráticos', cada vez mais imanentes ao campo social, distribuídos por corpos e cérebros dos cidadãos. (...) A sociedade de controle pode, (...), ser caracterizada por uma intensificação e uma síntese dos aparelhos de normalização e de disciplinariedade que animam nossas práticas diárias e comuns, mas, em contraste com a disciplina, esse controle estende bem para fora os locais estruturados de instituições sociais mediante redes flexíveis e flutuantes" (Hardt \& Negri, 2004, p. 42-43) 
Considerações Finais 
Esta pesquisa teve início com as questões levantadas durante meu estágio em Recursos Humanos com Treinamento e Desenvolvimento, ao final do curso de graduação em psicologia. Após observar diversos eventos organizacionais dirigidos aos trabalhadores, eventos estes muitas vezes estranhados pelos participantes, surgiu a pergunta: "A quem se dirige tais propostas, eventos e treinamentos?". Desta forma, o objetivo inicial pensado para nortear esta pesquisa foi "Quais noções de sujeito subsidiam os discursos e as práticas de Treinamentos para trabalhadores"? Dentre toda a gama de possibilidades, escolhemos enquadrar esta proposta focando nos treinamentos dirigidos à Qualidade de Vida dos Trabalhadores.

O primeiro choque entre o projeto e o contato com o campo se deu justamente durante o levantamento bibliográfico acerca do tema Qualidade de Vida no Trabalho. A tarefa, inicialmente planejada como passível de realização durante os dois primeiros trimestres, revelou-se inefável. Não apenas irrealizável durante o tempo previsto, mas absolutamente inviável, devido à multiplicidade de sentidos veiculados pelos diversos discursos que buscavam se apropriar do termo Qualidade de Vida no Trabalho. A impressão é que quanto mais se lia sobre o assunto, menos se compreendia suas origens, propostas e teorias. Após visitar e revisitar textos acadêmicos e comerciais sobre o assunto, delinearam-se linhas interpretativas com algumas afinidades. Mais que procurar separar entre verdades e inverdades, a proposta foi encontrar como cada uma destas linhas vinha a ter lugar entre os discursos que versavam sobre o tema. A idéia de "revisão bibliográfica" naufragou e as análises tomaram o rumo da arqueologia (Foucault, 1972).

A análise documental, portanto, não "precedeu" a entrada em campo, mas apresentou-se afirmativamente enquanto campo de pesquisa. Um campo simbólico 
que escorregava entre autores e buscava apresentar diversas perspectivas. De forma ampla, categorizamos as perspectivas em matrizes: Humanista, Sociotécnica e Qualidade Total. Autores de perspectiva crítica frente ao tema possibilitaram uma visão não comprometida com o mercado da QVT. Porém, dentre toda a análise documental realizada, o mais revelador não estava no que fora dito, mas justamente naquilo que foi interdito, "apagado" das entrelinhas dos discursos no decorrer dos anos: apesar de ser praticamente unânime a citação da Teoria Sociotécnica como origem das preocupações sobre a QVT, os textos excluem das suas características a questão da democracia industrial. É desta forma que os atuais discursos tendem a se apropriar do que foi dito, apresentando como "verdade" somente aquilo que permitem que seja dito neste momento e interditando aquilo que querem que seja esquecido.

Este contato com o tema alterou nossa idéia inicial daquilo que seria o campo de pesquisa. O campo passou a ser o tema Qualidade de Vida para os Trabalhadores e focamos na organização de poderes e saberes próprios a ele, não nos detendo a uma empresa somente.

O início da fase das entrevistas, por sua vez, apresentou uma realidade de mundo do trabalho mais ligada à configuração atual dos novos modelos de Gestão de Pessoas. Ao entrevistar responsáveis por programas de Qualidade de Vida para os Trabalhadores, noções como "competências", "atitudes" e "agregar valor à marca" surgiam copiosamente. Os programas observados não diziam respeito ao trabalhador do sistema fordista, mas ao sujeito do trabalho imaterial (Gorz, 2005). Porém, não havia uma simples ruptura dentre estas modalidades de organização do trabalho, mas a Gestão de Qualidade de Vida apresentava-se amparada em toda uma bricolage de práticas de gestão e exercícios de controle que hora retomava aos princípios tayloristas, hora remetia ao trabalho imaterial. Para compreendermos o contexto da atual Gestão de QVT, ressaltamos algumas características dos principais modelos de organização e gestão do trabalho.

Este caminho possibilitou visualizarmos o porque de tantos discursos voltados ao trabalhador acabarem por não tocar diretamente no tema trabalho: o sujeito do trabalho imaterial possui todos os espaços da sua vida tomados pelo intuito de se auto-produzir para a organização, logo, aborda-se o trabalho mesmo falando apenas 
de estilo de vida. O advento deste auto-empreendedor (Gorz, 2005) culmina com a internalização radical de toda a maquinaria de poder e controle desenvolvida desde Taylor. Traçar este percurso nos permitiu associar a atual idéia de Saúde presente nos programas observados com as noções de controle e disciplina.

Dentre os autores revisitados, Foucault foi quem forneceu mais subsídios para entendermos o discurso da qualidade de vida para os trabalhadores e sua idéia de "saúde" como mecanismo disciplinar de controle. Estes programas permitem aquilo que Foucault chama de criação de corpos dóceis e úteis (Foucault, 1977).

As atividades do $\mathrm{RH}$-Group apresentaram um espaço onde o discurso da qualidade de vida não somente afirmava o que é o "trabalhador saudável" (justamente aquele que é resiliente, ou seja, resistente às más condições de trabalho), mas apresentou-se também como um espaço onde se treinava, se praticava ser este trabalhador supostamente saudável. Observamos trabalhadores treinando a respiração ayur-védica, para cindirem com a realidade em momentos onde o trabalho estiver insuportável e sentirem-se como se estivessem em outro lugar. Observamos também como a qualidade de vida é disseminada de forma lúdica em empresas, associando Saúde à competitividade, mediante jogos corporativos.

A entrevista com Tereza apresentou outra dimensão do controle por trás do tema da Qualidade de Vida: não somente uma inserção molecular em corpos, mas toda uma proposta de Empresa Total mediada por um Programa de Qualidade de Vida para os Trabalhadores que, como a entrevistada afirmou, "parece que é um monstro de mil tentáculos" (Tereza)

Esta entrevistada apresentou também a transformação da promoção de QVT em prática de benchmark, onde a principal questão é agregar valor à marca por associar seu nome à qualidade de vida, não importando se os trabalhadores da empresa estão realmente assistidos em suas necessidades.

A noção de empresa total e benchmark, questões "pós" poder-disciplinar, apresentaram-se massivamente na Empresa ESB. O Programa Viver Feliz, responsável por todo o planejamento e execução das ações de qualidade de vida para os trabalhadores desta empresa, não almejava apenas seus funcionários, mas oficialmente destinava-se à toda a comunidade. Esta gestão de corpos enquanto espécie remeteu-nos à noção de biopoder (Foucault, 2005). 
Lazer, saúde, segurança e integração social são as dimensões onde o Programa de Qualidade de Vida da ESB busca atuar. Estes assuntos vão além do que se espera que seja área de atuação de uma empresa na vida de seus funcionários. As ações organizacionais correlativas buscam estimular e criar nos sujeitos uma suposta "consciência saudável". Retomemos agora à primeira pergunta que consideramos nortear este trabalho: “Quais noções de sujeito subsidiam estes programas de QVT?”

Falas como de Tereza, Marta, Jéferson e de participantes do RH-Group, que estranhavam as propostas relativas à QVT apresentadas, indicavam que a pergunta inicial não fazia sentido, ou melhor, era quase ingênua. Segundo Foucault, o lugar do sujeito no discurso é vacante, vazio. Percebemos exatamente isto nos discursos empresariais sobre a Qualidade de Vida dos Trabalhadores. Primeiro, porque estas organizações buscavam se apropriar dos enunciados sobre o tema para se fazer sujeito nestes. Inicialmente, o sujeito dos discursos corporativos observados sobre QVT é a organização e não o trabalhador. É para ela que este discurso age, é ela quem ele busca fortalecer. Segundo, porque a noção de sujeito que subsidia a idéia de trabalhador saudável, em torno da qual se estrutura este discurso, não existe.

Não existe, mas passa a existir, após configurado o discurso. O discurso da QVT estruturado no Manual Viver Feliz fala de um sujeito que não existe, mas que deseja criar com suas várias ações corporativas. Desta forma, não raro os trabalhadores da ESB demonstravam não se reconhecer naquele trabalhador-modelo descrito no manual e não compreendiam qual a importância de suas propostas. A idéia foucaultiana de que não são os sujeitos que criam os discursos, mas justamente o contrário, de que os discursos é que criam os sujeitos, fez sentido ao nos aprofundarmos no campo dos discursos de promoção de qualidade de vida aos trabalhadores.

Porém, não pudemos deixar de verificar também os limites da contribuição da concepção de poder disciplinar foucaultiana a esta pesquisa, principalmente em falas como a de Marta, quando encontramos trabalhadores que utilizavam o discurso da QV para expressar seus argumentos, ou seja, ela, Marta, se fazia sujeito utilizando o discurso que buscava assujeitá-la. A percepção do uso do discurso alheio, mostrando que o exercício do poder não é unilateral, está presente em outras pesquisas da área Psicologia do Trabalho, vide Sato (2002) e Sato \& Oliveira (2008). 
Sobre a multiplicidade das modalidades de exercício do poder e da disciplina no mundo do trabalho, também foi revelador a coexistência de seus diversos modos de exercício, principalmente as contradições dentro de uma mesma empresa, como a ESB, onde alguns trabalhadores estavam dispostos ao poder disciplinar, penetrante e sutil, enquanto outros trabalhadores, como os terceirizados, estavas imersos em modalidades violentas nada sutis de controle.

Neste sentido, a experiência de campo foi norteadora também no sentido de demonstrar os limites das teorias utilizadas.

Desta forma, esta pesquisa buscou nortear-se pelas especificidades do campo, respeitando suas características e tomando decisões metodológicas de acordo com as contínuas negociações nos cotidianos pesquisados.

Retomando as preocupações da Escola de Frankfurt, Silva (1997) afirma:

"Isto significa que quando se trata de conhecer o homem, trata-se de conhecer um sujeito histórico, e não apenas um sujeito dado. A subjetividade se institui no interrelacionamento das práticas constituintes do universo humano. Podemos num certo sentido dizer que o problema que está aqui colocado para todas as ciências humanas é o mesmo que está posto para a Psicologia: como fazer do sujeito um objeto, sem deixar de conhecê-lo como sujeito?" (Silva, 1997, p.26)

A fim de não transformarmos os trabalhadores pesquisados em simples objetos, buscamos estar atentos aos conselhos e indicações sempre que surgiam do campo. Assim é que damos crédito aos trabalhadores participantes desta pesquisa por indicarem caminhos a seguir e como recolocar as questões que levávamos ao campo, optando, desta forma, a buscar teorias e métodos que abarcassem a riqueza do campo, e não o contrário. 
Referências Bibliográficas 
Abreu, Y. F. A. (2004). Você S/A: análise do discurso da mídia sobre o trabalho a partir da analítica do poder de Michel Foucault. Dissertação (Mestrado em Administração) - Faculdade de Economia, Administração e Contabilidade da Universidade de São Paulo.

Albuquerque, L. G.; França, A. C. L., (1998) Estratégias de recursos humanos e gestão da qualidade de vida no trabalho: o stress e a expansão do conceito de qualidade total, Revista de Administração, v.33, no 2, São Paulo, abr./jun.

Antunes, R. (2007). Adeus ao Trabalho?: ensaio sobre as metamorfoses e a centralidade do mundo do trabalho. São Paulo: Cortez; Campinas, SP: Editora da Universidade Estadual de Campinas.

Araújo, I. L. (2008) Foucault e a crítica do sujeito. Curitiba-PR: Ed. da UFPR.

Arendt, H. (2007) Entre o Passado e o Futuro. 6a Ed, São Paulo: Perspectiva.

Ayres, K. V. S., I. P. Souto-Maior, R. C. (2004) Stress e qualidade de vida no trabalho: a percepção de profissionais do setor de hotelaria. In Anais - V Congresso de Stress da ISMA-BR e VI Fórum Internacional de Qualidade de Vida no Trabalho, Porto Alegre/RS.

Bakan, J. (2008) A Corporação: a busca patológica por lucro e poder. São Paulo: Novo Conceito.

Barros, C. A. C. (2003) Qualidade de Vida no Trabalho: Um Ferramental Para a Qualidade Total. Revista CADE - Universidade Moraes Junior - Mackenzie Rio, n.06, p.15 - 18. Disponível na Internet: http://www.mackenzierio.edu.br/pesquisa/cade6/qualidade_de_vida_no_trab.doc

Becker, H. (1999) Métodos de Pesquisa em Ciências Sociais. Ed. Hucitec, 4ạ. edição, São Paulo.

Bello, E. (2007) 'Bio-poder' e 'sociedade de controle': duas contribuições de Michel Foucault para a análise social e política dos direitos humanos. Disponível na Internet: http://www.mundojuridico.adv.br. 
Bernardo, M. H. (2001). Riscos na usina química: os acidentes e a contaminação nas representações dos trabalhadores. Dissertação de Mestrado, Instituto de Psicologia, Universidade de São Paulo, São Paulo.

Biazzi Jr., F. (1994). O trabalho e as organizações na perspectiva sociotécnica. Revista de Administração de Empresas, 34 (1), 30-37.

Braga, S. R.; Vlach, V. R. F. (2004) Os usos políticos da tecnologia, o biopoder e a sociedade de controle: considerações preliminares. Revista Scripta Nova (Barcelona), Barcelona-Espanha, v. VIII, n. 170, p. 1-15.

Brito, L. M. P. (2005) Gestão de competências, gestão do conhecimento e organizações de aprendizagem: instrumentos de apropriação pelo capital do saber do trabalhador. Fortaleza: Imprensa Universitária.

Certeau, M. (1997) A Invenção do Cotidiano: 1. Artes de Fazer. Rio de Janeiro: Vozes.

Chauí, M. S. (2006) Cultura e democracia. O discurso competente e outras falas. Nova edição revista e ampliada. 11. ed. São Paulo: Editora Cortez.

Coriat, B. (1994) Pensar pelo avesso: o modelo japonês de trabalho e organização. Rio de Janeiro: Revan: UFRJ.

Davenport, T. H. (2002) Ecologia da Informação. São Paulo: Futura.

Deetz, S. (1992) - Disciplinary Power in Modern Corporation. In: Alvesson, M \& Willmott, H. (1992) eds. - Critical Management Studies. Sage.

Dejours, C., Abdoucheli, E. (1994) Itinerário teórico em Psicopatologia do Trabalho. In: Dejours, C., Abdoucheli, E. e Jayet, C. Psicodinâmica do Trabalho: contribuições da Escola Dejouriana à análise da relação prazer, sofrimento e trabalho. São Paulo: Atlas.

Deleuze, G. (2002); Conversações. São Paulo: Editora 34. 
Deluiz, N. (2001) O modelo das competências profissionais no mundo do trabalho e na educação:implicações para o currículo. Boletim Técnico do SENAC, Rio de Janeiro, v. 27, n. 3, p. $13-25$.

Detoni, D. J. (2001) Estratégias de avaliação da qualidade de vida no trabalho: estudo de caso em agroindústria. Dissertação de Mestrado: Engenharia de Produção, UFSC.

Druck, G.; Franco, T. (2007) A perda da razão social do trabalho: terceirização $e$ precarização. São Paulo: Boitempo.

Drucker, P. F. (1995) Administrando em Tempos de Grandes Mudanças. São Paulo: Pioneira.

Drucker, P. F. (2000) Desafios Gerenciais para o século XXI. São Paulo: Pioneira.

Ezpeleta, J. \& Rockwell, E. (1986). Pesquisa Participante. São Paulo, Cortez.

Fernandes, E.C.; Gutierrez, L. H. (1998) Qualidade de vida no trabalho (QVT): uma experiência brasileira. Revista de Administração da USP, v. 23, n. 4, p. 29-31-32, 0 ut./Dez..

Fernandes, E. C. (1996) Qualidade de vida no trabalho: como medir para melhorar. Salvador: Casa da Qualidade.

Filho, J. M. G. (1995). Passagem para a Vila Joanisa - Uma introdução ao problema da humilhação social. Dissertação de Mestrado, Instituto de Psicologia, USP. São Paulo.

Fleury, A., Fleury, M. T. L. (2000) Estratégias empresariais e formação de competências: um quebra-cabeça caleidoscópio da indústria brasileira. São Paulo: Atlas.

Foucault, M. (1972) A Arqueologia do Saber. Traduçao de Luiz Felipe Baeta Neves, revisão de Ligia Vassalo. Petrópolis: Vozes, Lisboa : Centro do Livro Brasileiro. 
Foucault, M. (1977) História da Sexualidade vol I - A Vontade de Saber. Rio de Janeiro, Ed. Graal

Foucault, M. (1979) Microfísica do poder. Rio de Janeiro, Graal.

Foucault, M. (1997). Vigiar e Punir. Tradução de Raquel Ramalhete, 16ㅇe ed. Editora Vozes. Petrópolis, RJ.

Foucault, M. (2005) Em defesa da sociedade: Curso no Collège de France (1975-1976), (trad. De Maria Ermantina Galvão). São Paulo: Martins Fontes.

Foucault, M. (2006). A ordem do discurso. $14^{\circ}$ ed, Loyola: São Paulo.

França, A.C.L. ; Bosquettil, M. A.; Veloso, H. M. (2005) A Concepção Gerencial dos Programas de Qualidade de Vida no Trabalho (QVT) no Setor Elétrico Brasileiro. In: VIII SEMEAD - Seminários em Administração, v. 1. p. 1-15. São Paulo: USP-FEA. Depto Administração.

Gardell, B. (1982). Scandinavian research on stress in working life. International Journal of Health Services, 12(1):31-41.

Geertz, C. (1989). A interpretação das Culturas. Rio de Janeiro, Guanabara.

Giddens, A. (1991). As conseqüências da modernidade. São Paulo: UNESP.

Gorz, A. (2005). O Imaterial: Conhecimento, Valor e Capital. São Paulo: Annablume.

Hack R. F. (2006). Michel Foucault e a individuação discursiva. Tempo da Ciência ( 13 ) $26: 25-38,20$ semestre.

Hardt, M.; Negri, A. (2004) Império. 6ạ ed., Rio de Janeiro: Record.

Harvey, D. (1992) A Condição Pós-Moderna. São Paulo, Ed. Loyola.

Heller, A. (1970) O cotidiano e a História. São Paulo: Paz e Terra.

Heloani, R. J. (1994). Organização do trabalho e administração: uma visão multidisciplinar. São Paulo: Cortez. 
Heloani, R. J. (2003) Gestão e organização no capitalismo globalizado. História da manipulação psicológica no mundo do trabalho, São Paulo: Atlas.

Heloani, R. J.; Capitão, C. G. (2003) Saúde Mental e Psicologia do Trabalho. São Paulo em Perspectiva, 17(2): $102-108$.

Herzberg, F. (1959) The motivation to work. Nova York: Wiley.

Hirata, H. e Zarifian, P. (1991). "Força e fragilidade do modelo japonês". Estudos Avançados, 12(5).

Kompier, M. A. J. \& Kristensen, T. S. (2003). As intervenções em estresse organizacional: considerações teóricas, metodológicas e práticas. Cadernos de Psicologia Social e do Trabalho, vol. 6, pp. 37-58.

Lacaz, F. A. C. (2000). Qualidade de Vida no Trabalho e Saúde/Doença. Ciência \& Saúde Coletiva, vol.5, no.1, p.151-161.

Lebrun, G. (1984) O que é poder? São Paulo: Brasiliense

Lima, A. B. \& Oliveira, F. (1995). Abordagem Psicossocial da LER: Ideologia e culpabilização e grupos de qualidade de vida. In: LER. Diagnóstico, Tratamento e Prevenção. Uma Abordagem Interdisciplinar (W. Codo \& M. C. Almeida, org.), p. 136-159, Petrópolis: Editora Vozes.

Lima, I. S. (1995). Qualidade de Vida no Trabalho na construção de edificações: avaliação do nível de satisfação dos operários de empresas de pequeno porte. Tese de Doutorado. Universidade Federal de Santa Catarina - Curso de PósGraduação em Engenharia de Produção.

Limongi-França, A. C., (2007), Qualidade de vida no trabalho - QVT. Conceitos $e$ práticas nas empresas da sociedade pós-industrial, São Paulo: Atlas.

Limongi-França, A. C., Oliveira, P. M. (2005). Avaliação da Gestão de Programas de Qualidade de Vida no Trabalho. RAE - Eletrônica (FGV), v.4, no 4, São Paulo, jan./jul. 
Lipovetsky, G. \& Sebastien, C. (2004) Os Tempos Hipermodernos. Tradução de Mario Vilela. Ed. Barcarolla

Maia, A. C. (2003). Biopoder, biopolítica e o tempo presente. In: Novaes, A. (Org.). O homem máquina: a ciência manipula o corpo. São Paulo: Cia. das Letras, p. $77 / 108$.

Martins, J. S. (1993). A aparição do demônio na fábrica, no meio da produção. Tempo Social; Rev. Sociol. USP, São Paulo, 5 (1-2); pp. 1-29.

Monaco, F. F. \& Guimarães, V. N. (2000) Gestão da Qualidade Total e Qualidade de Vida no Trabalho. Revista de Administração de Empresas Contemporânea-RAC vol. 4 , no.3, set/dez.

Morgan, G. (1986) Images of Organization. Sage.

Oliveira, F. (1997). A construção social dos discursos sobre o acidente do trabalho. Dissertação de Mestrado. Instituto de Psicologia, USP, São Paulo.

Oliveira, E. (2004). Toyotismo no Brasil: Desencantamento da Fábrica, Envolvimento e Resistência. Expressão Popular, São Paulo - SP.

Prahalad \& Hamel, (1990). The Core Competence of The Corporation. In Harvard Business Review, may-june.

Rechziegel, W; Vanalle, R. M. (1999). Qualidade de vida no trabalho e a gestão da qualidade total. Revista de Negócios, Blumenau, v. 4, n. 4, p. 31-37

Rockwell, E. (1987). Reflexiones sobre el processo etnográfico (1982-85). México, DIE/CINVESTAV, IPN.

Rodrigues, C. M. C. (1998) Qualidade de vida no trabalho (QVT) e sua influência na filosofia de qualidade total: estudo realizado em nível gerencial em indústrias frigoríficas. In: 8. Congresso Brasileiro de Ergonomia. Anais... Florianópolis : ABERGO - Associação Brasileira de Ergonomia. p. 863 - 869. 
Rodrigues, M. V. (1999) Qualidade de Vida no Trabalho: Evolução e Análise no Nível Gerencial. Petrópolis: Editora Vozes.

Sartre, J-P. (1973) Questão de Método. São Paulo, Ed. Abril Cultural (Coleção Os Pensadores).

Sato, L. (1993). A representação social do trabalho penoso. In: M. J. P. Spink, (Org.), O Conhecimento no Cotidiano - As Representações Sociais na Perspectiva da Psicologia Social (pp. 188-211). São Paulo: Brasiliense.

Sato, L. (1997). Astúcia e Ambigüidade: as Condições Simbólicas para o Replanejamento Negociado do Trabalho no Chão de Fábrica. Tese de Doutorado. Instituto de Psicologia, USP, São Paulo.

Sato, L. \& Souza, M. P. R. (2001) Contribuindo para desvelar a complexidade do cotidiano através da pesquisa etnográfica em Psicologia. Psicologia USP, São Paulo, v. 12, n. 2.

Sato, L. (2002). Prevenção de agravos à saúde do trabalhador: replanejando o trabalho através das negociações cotidianas. Cad. Saúde Pública, vol.18, no. 5, p.11471157.

Sato, L. (2003). Psicologia, Saúde e Trabalho: distintas construções dos objetos Trabalho e Organização. In: Trindade Z. A. \& Andrade A. N. (Org.). Psicologia, Saúde: um campo em construção. $1^{\circ}$ ed. São Paulo: Casa do Psicólogo, v. 1, p. 167-178.

Sato, L.; Oliveira, F. (2008). Compreender a Gestão a partir do cotidiano de trabalho. Revista Aletheia, 27(1), p. 188-197, jan./jun.

SEBRAE. (2006). Principais apontamentos do Programa Negócios \& Soluções de 26/01/2006 Tema: Qualidade Total Disponível na Internet: http://www.sebraesp.com.br/topo/produtos/documentos produtos/documento $\underline{s \text { negocios solucoes/qualidade total.doc }}$ 
Schramm, F. R. E. (1997) Eugenética e o espectro do Eugenismo: considerações atuais sobre biotecnociencia e bioética. Bioética. Brasilia - DF: Conselho Federal de Medicina, 1997, vol. V, $n^{\circ} 2$.

Senge, P. M. (1998) A Quinta Disciplina: Arte e Prática da Organização de Aprendizagem, (2nd ed.), São Paulo: Editora Best Seller Círculo do Livro.

Silva, L. V. (2001) Qualidade de Vida do Trabalhador na Springer Carrier: uma análise dos principais Programas e Políticas da Empresa num contexto de flexibilização do trabalho. Dissertação de Mestrado, Faculdade de Administração da Universidade Federal do Rio Grande do Sul - Porto Alegre.

Silva, F. L. (1997) Conhecimento e Razão Instrumental. Psicologia USP, São Paulo, v. 8, n. 1, p.11-31.

Silveira, R. A. (2005). Michel Foucault: Poder e análise das organizações. Editora FGV, São Paulo.

Siqueira, M. V. S. (2004) Discurso organizacional em recursos humanos e a subjetividade do indivíduo - uma análise crítica. Tese de Doutorado, Escola de Administração da Fundação Getúlio Vargas, São Paulo.

Spink, P. K. (1982a). Quando Trabalhar é Neurotizante. Psicologia Atual, v. 5, n. 27, p. $16-20$.

Spink, P. K. (1982b). Democracia no local de trabalho. Ou a gerência sabe o que é melhor? Psicologia Atual, n. 28, p. 37-41.

Spink, P. K. (1991). Saúde mental e trabalho: O bloqueio de uma prática acessível. In: Psicologia e Saúde - Repensando Práticas (F. C. B. Campos, org.), pp. 91-102, São Paulo: Editora Hucitec.

Spink P. K. (1996). Organização como fenômeno psicossocial: notas para uma redefinição da psicologia do trabalho; Psicologia \& Sociedade; 8(1): 174-192; jan./jun. 
Spink, P. K. (2003a). A perda, redescoberta e transformação de uma tradição de trabalho: a teoria sociotécnica nos dias de hoje. Organizações e Sociedade, 10, 28, p. 117-130.

Spink, P. K. (2003b) Pesquisa de Campo em Psicologia Social: Uma Perspectiva PósConstrucionista. Psicologia e Sociedade, v. 15, n. 2, p. 18-24.

Sveiby, K. E. (1997). The new organizational wealth: managing and measuring. San Francisco: Berrett-Koehler, 1997.

Tolfo, S.R. \& Piccinini,V.C. (1998). As Melhores Empresas para Trabalhar no Brasil e a qualidade de vida no trabalho: Disfunções entre a Teoria e a Prática. In Anais do 22 ENANPAD.-rh . 4.

Vasconcelos, A. F. (2001), Qualidade de vida no trabalho: origem, evolução e perspectivas. In: Caderno de Pesquisas em Administração, SP, v.08, № 1, jan./mar.

Vieira, A. (1996) A qualidade de vida no trabalho e o controle de qualidade total. $1^{\circ}$ ed. Florianópolis: Insular.

Xavier A. A. P.; Quilici, R. F. M. (2006) Qualidade de Vida no Trabalho (QVT) em uma empresa estocadora de soja na região dos Campos Gerais: um estudo comparativo sobre satisfação/motivação. In: XXVI Encontro Nacional de Engenharia de Produção, 2006, Fortaleza. CD XXVI ENEGEP.

Walton, R. E. (1973) Quality of Working Life: What is it? Sloan Management Review. Vol. 15, n. 1, p. 11-21.

Westley, W. (1979) A Qualidade de vida no trabalho: problemas e soluções. Rio de Janeiro: Incisa.

Zavattaro, H. A. (1999). A Qualidade de Vida no Trabalho de Profissionais da Área de Informática: um Estudo Exploratório. Dissertação de mestrado. Instituto de Psicologia, USP, São Paulo. 